\title{
One and Inseparable: Dilution and Infringement in Trademark Law
}

\author{
Gerard N. Magliocca ${ }^{\dagger}$
}

[T]he proper expansion of trademark law has been hampered by obsolete conceptions both as to the function of a trademark and as to the need for its protection....

-Professor Frank I. Schechter (1927)

[T] in the form proposed by Schechter, ... [and] has puzzled courts from the outset as to just exactly what legal interest it sought to protect....

-Ringling Bros.-Barnum \& Bailey Combined Shows, Inc. v. Utah Division of Travel Development. ${ }^{2}$

Breakfast at Tiffany's. The very phrase evokes a cosmopolitan world of cocktail parties, cigarette holders, and sparkling conversation that forms the backdrop of Truman Capote's tale of loneliness and longing. ${ }^{3}$ Capote's choice of Tiffany to establish a mood of elegant sophistication in his title was no small matter. Consider an alternative like Breakfast at Denny's. It might be a great title for something, but the image conjured up is-to put it mildly - not the same.

Such is the power of trademarks to convey information. ${ }^{4}$ And as the Supreme Court has explained, "[T]rademark law, by

$\dagger$ Associate, Covington \& Burling. J.D., Yale Law School, 1998; B.A., Stanford University, 1995. Many thanks to Bruce Ackerman, Guido Calabresi, Jon Oram, and Richard Primus for their insights. This Article does not represent the views of Covington \& Burling or its clients.

1. Frank I. Schechter, The Rational Basis of Trademark Protection, 40 HARV. L. REV. 813, 824 (1927).

2. 170 F.3d 449, 456 (4th Cir. 1999), cert. denied, 528 U.S. 923 (1999).

3. See generally TRUMAN CAPOTE, BREAKFAST AT TIFFANY'S (1958).

4. Of course, trademark law covers more than words like "Tiffany" and "Denny's." See 15 U.S.C. \$ 1127 (1994) (stating that trademarks include "any word, name, symbol, or device or any combination thereof'). One example is trade dress, which refers to "that arrangement of identifying characteristics connected with a product, whether by packaging or otherwise, intended to 
preventing others from copying a source-identifying mark, reduce[s] the customer's costs of shopping and making purchasing decisions." 5 This is because "a potential customer [is assured] that this item-the item with this mark-is made by the same producer as other similarly marked items that he or she liked (or disliked) in the past."6 Moreover, "the law helps assure a producer that it (and not an imitating competitor) will reap the financial, reputation-related rewards associated with a desirable product."7

Although the purpose of trademark protection is clear, the framework for evaluating trademark claims has become quite muddled. ${ }^{8}$ Traditionally, mark owners seeking to enjoin unauthorized uses of their mark have been required to show that the unauthorized use creates a "likelihood of consumer confusion" under infringement theory. ${ }^{9}$ In recent years, however, an alternative approach to protecting marks-dilution-has gained a considerable following. ${ }^{10}$ Unlike infringement, dilution does

make the source of the product distinguishable from another and to promote its sale." Esercizio v. Roberts, 944 F.2d 1235, 1239-40 (6th Cir. 1991). When trade dress is alleged in the good itself rather than in its packaging, protection of the so-called "product configuration" is sometimes treated differently from ordinary marks and trade dress. Duraco Prods., Inc. v. Joy Plastic Enters., Ltd., 40 F.3d 1431, 1434 (3d Cir. 1994). For ease of reading, the terms "marks" and "trademarks" will be used interchangeably to refer to all valid representations of commercial identity.

5. Qualitex Co. v. Jacobson Prods. Co., 514 U.S. 159, 163 (1995) (internal citations and quotation marks omitted).

6. Id. at 164.

7. Id.

8. See, e.g., David L. Lange, The Intellectual Property Clause in Contemporary Trademark Law: An Appreciation of Two Recent Essays and Some Thoughts About Why We Ought to Care, 59 LAW \& CONTEMP. PROBS. 213, 222 (1996) ("In the field of trademarks and unfair competition, ... it often seems that the river is over its banks; the boundaries among doctrines are no longer clear.").

9. 15 U.S.C. $\$ 1125(\mathrm{a})$; see, e.g., Brookfield Communications, Inc. v. West Coast Entm't Corp., 174 F.3d 1036, 1053 (9th Cir. 1999); Patrick M. Bible, Defining and Quantifying Dilution Under the Federal Trademark Dilution Act of 1995: Using Survey Evidence to Show Actual Dilution, 70 U. Colo. L. REv. 295, 296-98 (1999); Robert N. Klieger, Trademark Dilution: The Whittling Away of the Rational Basis for Trademark Protection, 58 U. PITT. L. REV. 789, 792 (1997).

10. For more on dilution, see, e.g., Nabisco, Inc. v. PF Brands, Inc., 191 F.3d 208, 214-28 (2d Cir. 1999); Ringling Bros.-Barnum \& Bailey Combined Shows, Inc. v. Utah Div. of Travel Dev., 170 F.3d 449, 453-58 (4th Cir. 1999), cert. denied, 528 U.S. 923 (1999); 4 J. THOMAS MCCARTHY, MCCARTHY ON TRADEMARKS AND UNFAIR COMPETITION $§ 24: 90$ (4th ed. 2000); Elizabeth Cutter Bannon, Revisiting The Rational Basis of Trademark Protection: Control of 
not require a finding of likely consumer confusion. ${ }^{11}$ The founder of dilution, Frank I. Schechter, believed that the real injury caused by concurrent uses of a mark was not consumer confusion, but was "the gradual whittling away or dispersion of the identity and hold upon the public mind of the mark or name by its use upon non-competing goods."12 Accordingly, under dilution laws a mark owner need only establish that an unauthorized use creates a likelihood of dilution to the mark's distinctiveness. ${ }^{13}$

The enactment of the Federal Trademark Dilution Act of $1995^{14}$ (FTDA) opened a wide rift between the supporters of infringement and dilution. ${ }^{15}$ Prior to the FTDA's arrival, the fundamental differences between these two models of trademark protection did not present a serious problem because dilution was a remedy available only in a minority of states. ${ }^{16}$ But the elevation of dilution into a federal question has raised the stakes for those on both sides of the debate who believe that

Quality and Dilution-Estranged Bedfellows?, 24 J. MARSHALL L. REV. 65, 90109 (1990). See generally Klieger, supra note 9; David S. Welkowitz, Reexamining Trademark Dilution, 44 VAND. L. REv. 531 (1991); Note, Dilution: Trademark Infringement or Will-O'-The-Wisp, 77 HARV. L. REV. 520 (1964).

Klieger's article is the most influential analysis of dilution in the recent literature. See, e.g, Ringling Bros., 170 F.3d at 454, 460 (citing Klieger, supra note 9).

11. See, e.g., Avery Dennison Corp. v. Sumpton, 189 F.3d 868, 873 (9th Cir. 1999); I.P. Lund Trading ApS v. Kohler Co., 163 F.3d 27, 36 (1st Cir. 1998); Allied Maintenance Corp. v. Allied Mechanical Trades, Inc., 369 N.E.2d 1162, 1164-66 (N.Y. 1977); Jessica Litman, Breakfast with Batman: The Public Interest in the Advertising Age, 108 YALE L.J. 1717, 1723-24 (1999).

12. Schechter, supra note 1 , at 825 . Many dilution statutes have expanded Schechter's concept to include competing as well as non-competing goods. See infra text accompanying note 68.

13. See, e.g., Wedgwood Homes, Inc. v. Lund, 659 P.2d 377, 378 (Or. 1983); Model State Trademark Act $\S 12$ (1964), reprinted in 3 J. THOMAS MCCARTHY, MCCARTHY ON TRADEMARKS AND UNFAIR COMPETITION § 22:8 (4th ed. 2000). For more on the definition of dilution, see infra text accompanying notes 69-75.

14. Pub. L. No. 104-98, 109 Stat. 985 (codified at 15 U.S.C. $\$ \S 1125,1127$ ).

15. See id.; see also Ringling Bros., 170 F.3d at 455-56; Gregg Duffey, Trademark Dilution Act of 1995: You've Come a Long Way Baby-Too Far, Maybe?, 39 S. TEX. L. REV. 133, 135 (1997); Klieger, supra note 9, at 795.

16. See, e.g., Ringling Bros., 170 F.3d at 454 (noting that about half of the states enacted a dilution remedy prior to the passage of the FTDA). While the conflict between dilution and infringement remained muffled until recently, the issue was never totally ignored. See, e.g., Ralph S. Brown, Jr., Advertising and the Public Interest: Legal Protection of Trade Symbols, 57 YALE L.J. 1165, 1191-98 (1948) (criticizing the dilution formula). 
infringement and dilution are incompatible and cannot coexist in the long run. ${ }^{17}$

Since the Supreme Court has not yet examined the relationship between infringement and dilution, each trademark camp has turned to the time-honored tactic of hurling brickbats at the other. For proponents of infringement, dilution is "a radical and imprudent alternative to the consumer protection model of trademark rights" that threatens to create property rights in gross for marks. ${ }^{18}$ Moreover, they fear that unless dilution laws are harshly restricted by the courts, the dilution concept could swallow up infringement entirely. ${ }^{19}$ Advocates of dilution, on the other hand, insist that marks should be treated like property and protected from uses that are not covered by the likelihood of confusion test. ${ }^{20}$ Dilutionists complain that courts frequently ignore the literal terms of dilution statutes and read onerous requirements into them in order to preserve infringement as the sole trademark remedy. ${ }^{21}$

17. See, e.g., RESTATEMENT (THIRD) OF UNFAIR COMPETITION $\S 25 \mathrm{cmt}$. b (1995) ("A broad antidilution theory also has the potential to render superfluous the traditional likelihood of confusion standard of liability."); Klieger, supra note 9, at 865 ("The [FTDA] seems well on its way to displacing the consumer protection model with a system of trademark rights in gross."); Mark A. Lemley, The Modern Lanham Act and the Death of Common Sense, 108 YALE L.J. 1687, 1697 (1999) ("Courts seem to be replacing the traditional rationale for trademark law with a conception of trademarks as property rights.").

18. Klieger, supra note 9, at 795; see Ringling Bros., 170 F.3d at 456 (explaining that the FTDA could "create property rights in gross in the narrow category of marks it protected, making them comparable (though without their time-limits) to those protected by patent and copyright law"); I.P. Lund Trading ApS v. Kohler Co., 163 F.3d 27, 51-52 (1st Cir. 1998) (Boudin, J., concurring) (stating that dilution claims for trade dress may present constitutional difficulties under the Patent Clause); Welkowitz, supra note 10, at 532 ("[Dilution] has the potential for granting a virtual exclusive property right in a trademark to its owner, something that traditional trademark law has eschewed.").

19. See Welkowitz, supra note 10, at 588; see also Klieger, supra note 9, at 865-66 ("Unless these state [dilution] statutes and the Federal Trademark Dilution Act are repealed or read into obscurity by the courts, trademark law's historic balance between free and fair competition will falter.").

20. See, e.g., Bannon, supra note 10, at 71-72; Kristine M. Boylan, The Corporate Right of Publicity in Federal Dilution Legislation Part II, 82 J. PAT. \& TRADEMARK OFF. SOC'Y 5, 17-19 (2000); Rudolf Callmann, Unfair Competition Without Competition?, 95 U. PA. L. REV. 443, 461 (1947); Note, supra note 10 , at 523.

21. See Klieger, supra note 9 , at 815-19 (summarizing the hostile attitude of the courts toward dilution after the 1940s); Beverly W. Pattishall, The Dilution Rationale for Trademark-Trade Identity Protection, Its Progress and Prospects, 71 Nw. U. L. REV. 618, 621 (1976) ("[T]he [dilution] concept seem- 
This battle for supremacy within trademark law is aggravated by the vagueness of the dilution concept. Courts repeatedly throw up their hands in frustration when asked "to identify the legal interest sought to be protected from 'dilution,' [and] hence the legal harm sought to be prevented."22 Since any concurrent use of a mark diminishes that mark's distinctiveness in some sense, separating unauthorized uses that dilute from those that do not has proven quite difficult. ${ }^{23}$ Unless dilution is read to prohibit virtually all unauthorized uses of a given mark, the doctrine can begin "to lose its coherence as a legally enforceable norm." 24

Although the elusive quality of dilution gives ammunition to its enemies, the theory was a popular tool to resolve trademark disputes on the Internet. ${ }^{25}$ Whether the issue was do-

ingly has remained so misunderstood or unpalatable to the judicial taste that it largely has been ignored by the courts despite the plain dictates of the statutes and the voluminous urgings of academics." (footnote omitted)); Note, supra note 10, at 528 (commenting on "[t]he persistence and ingenuity displayed by able federal judges in drawing the teeth of state dilution statutes"); cf. Ringling Bros., 170 F.3d at 464 (reading the FTDA to require proof of actual dilution even though such "[p]roof will be difficult").

22. Ringling Bros., 170 F.3d at 456; see Sally Gee, Inc. v. Myra Hogan, Inc., 699 F.2d 621, 625 (2d Cir. 1983) (calling dilution a "nebulous concept"); Welkowitz, supra note 10, at 533 ("The courts are foundering hopelessly in their efforts to promulgate a rational structure for analyzing dilution cases. Whatever the merits of dilution protection in theory, it is producing a confusing body of case law.").

23. See Ringling Bros., 170 F.3d at 456-57; Klieger, supra note 9, at 821; Note, supra note 10, at 529; see also Nabisco, Inc. v. PF Brands, Inc., 191 F.3d 208, 217 ( $2 \mathrm{~d}$ Cir. 1999) ("It is not yet entirely clear how courts should determine whether a junior use causes a senior mark to suffer dilution."). The term "junior user" refers to a party that uses a mark resembling one that is already registered, or in commercial use by someone else (the senior user). See $\mathrm{Na}$ bisco, 191 F.3d at 215. Depending on its distinctiveness, junior users sometimes have rights with respect to an existing mark, although the senior user ordinarily has priority. See id. at 216-17.

24. Ringling Bros., 170 F.3d at 455-56; see also Avery Dennison Corp. v. Sumpton, 189 F.3d 868, 875 (9th Cir. 1999) (noting that "a carefully-crafted balance exists between protecting a trademark and permitting non-infringing uses"); Klieger, supra note 9, at 821; $c f$. Schechter, supra note 1, at 831 ("[T] he preservation of the uniqueness of a trademark should constitute the only rational basis for its protection ....").

25. See Duffey, supra note 15, at 148-49; Ira S. Nathenson, Internet Infoglut and Invisible Ink: Spamdexing Search Engines with Meta Tags, 12 HARV. J.L. \& TECH. 43, 118-21 (1998) (advocating dilution as the best approach to metatag regulation). See generally Scott N. Barker, Note, Famous.com: Applying the FTDA to Internet Domain Names, 22 U. DAYTON L. REV. 265 (1997) (proposing that "the federal trademark dilution statute should be applied to Internet domain names that are similar to trademarks"). 
main name ownership or the abuse of search engine metatags, dilution was often the remedy of choice. ${ }^{26}$ Even the doctrine's sharpest critics maintained a curious silence with respect to dilution's application in cyberspace. ${ }^{27}$ This suggests that while the rationale for dilution remains unsatisfactory, the result of successful dilution actions-trademark protection-is still desirable in some circumstances where no likelihood of confusion exists.

This Article recharacterizes the relationship between infringement and dilution and formulates principles for the appropriate use of dilution. Upon careful examination, the view that these two paradigms of trademark protection are irreconcilable dissolves. Instead, infringement and dilution are complementary doctrines focused on a single goal: preventing the substantial impairment of trademark functions. To see the underlying unity of trademark law, however, dilution must be read as a limited remedy for infringement obsolescence. ${ }^{28}$

Most of the time, the means developed by the common law to protect trademark functions-infringement and the consumer confusion test-do the trick. But we cannot mix up means with ends. Consumer confusion is a fallible term of art for trademark protection, not a magic talisman. ${ }^{29}$ During the first half of the twentieth century, the scope of consumer confusion was widely criticized as too narrow to safeguard marks in the wake of the Industrial Revolution. ${ }^{30}$ Then, from the $1940 \mathrm{~s}$

26. See, e.g., Panavision Int'l L.P. v. Toeppen, 141 F.3d 1316, 1326-27 (9th Cir. 1998); 141 CONG. REC. S19312 (daily ed. Dec. 29, 1995) (statement of Sen. Leahy) ("[I]t is my hope that [the FTDA] can help stem the use of deceptive Internet addresses taken by those who are choosing marks that are associated with the products and reputations of others."); Nathenson, supra note 25, at 118-21. But see Jennifer Golinveaux, What's in a Domain Name: Is "Cybersquatting" Trademark Dilution?, 33 U.S.F. L. REV. 641, 671 (1999) (concluding that dilution should not be used to address domain name disputes). For more on trademarks and the Internet, see infra Part VI.

27. See, e.g., Duffey, supra note 15, at 135; Lemley, supra note 17, at 1701-03.

28. "Obsolescence" in this context refers to legal standards that are inadequate because they are based on pragmatic assumptions made under substantially different economic and social conditions.

29. See, e.g., Lange, supra note 8 , at 240 ("[C]onfusion is often little or nothing more than a makeweight, observed ex hypothesi.").

30. See, e.g., Bible, supra note 9, at 296-301; Brown, supra note 16, at 1195-98; Klieger, supra note 9, at 800-11. See generally FRANK I. SCHECHTER, THE HISTORICAL FOUNDATIONS OF THE LAW RELATING TO TRADE-MARKS (1925) (offering a broad critique of early twentieth century trademark doctrine). 
until the early 1960s, infringement cases were analyzed under a framework that had a problematic relationship to confusion. ${ }^{31}$ And recently, the consumer confusion concept has again come under attack as incapable of handling the arrival of the Information Age. ${ }^{32}$

At the heart of each of these examples is the pragmatic relationship between economic change and trademark doctrine. Over the last century, structural changes in the marketplace have periodically altered the commercial function of marks. When these rare and profound structural events occur, infringement may initially fail in its goal of protecting trademark functions from substantial impairment. This happens because infringement remains mired in an outdated understanding of what marks are supposed to do. Eventually, the common law addresses this legal obsolescence by expanding the definition of consumer confusion, well beyond what was once thought possible, to meet the new marketing practices. ${ }^{33}$ In the interim period, however, infringement doctrine can impede the development of new channels of commerce by underprotecting marks that consumers rely upon for information.

Dilution is best understood as the transitional law of trademark. ${ }^{34}$ By dispensing with the consumer confusion re-

31. See S.C. Johnson \& Son, Inc. v. Johnson, 175 F.2d 176, 180 (2d Cir. 1949) (L. Hand, C.J.) (establishing that trademark infringement extended to uses on non-competing products if the unauthorized use might "stain the [mark] owner's reputation in the minds of his customers"); Justin Hughes, "Recoding" Intellectual Property and Overlooked Audience Interests, 77 TEX. L. REV. 923, 998 (1999) (noting the paradox that "the likelihood of confusion ... is arguably increased the more the infringing goods are of the same quality as the trademark owner's goods" notwithstanding the doctrine's opposite position); see also Polaroid Corp. v. Polarad Elecs. Corp., 287 F.2d 492, 495 (2d Cir. 1961) (Friendly, J.) (analyzing infringement under the modern eight-factor test).

32. See, e.g., Duffey, supra note 15, at 147-49; Nathenson, supra note 25, at $111-15$.

33. "Common law" in this context refers to the judicial elaboration of statutes that have delegated broad lawmaking authority to the courts. Since the middle of this century, trademark law has been based on broad statutes such as the Lanham Act. See Lanham Trade-Mark Act, 15 U.S.C. $\$ \$ 1051-1127$ (1994) (the Lanham Act); see also Stephen L. Carter, The Trouble With Trademark, 99 YALE L.J. 759, 759 n.1 (1990) (explaining that federal trademark statutes prior to the Lanham Act did not create substantive rights).

34. Dilution is one of many doctrines that update obsolete intellectual property law. See Bruce P. Keller, Condemned To Repeat the Past: The Reemergence of Misappropriation and Other Common Law Theories of Protection for Intellectual Property, 11 HARV. J.L. \& TECH. 401, 412 (1997); Douglas Gary Lichtman, The Economics of Innovation: Protecting Unpatentable Goods, 81 
quirement, Schechter enabled courts to provide relief in circumstances where they otherwise could not because the definition of confusion had become obsolete. ${ }^{35}$ Although Schechter himself envisioned a broader role for dilution, a more limited version has gradually emerged from courts struggling to protect the changing function of marks in our economy. Once dilution is construed as an infringement obsolescence remedy, rather than as a comprehensive effort to reinvent trademark law, many mysteries of dilution doctrine can be solved. ${ }^{36}$

With the explosion in Internet commerce, we have seen another transition for marks and a corresponding renaissance in dilution law. After the upheaval of the Industrial Revolution, marks primarily became symbols of quality rather than indicators of source. ${ }^{37}$ This shift led directly to Schechter's dilution proposal. ${ }^{38}$ In cyberspace, web sites have made marks increasingly important as indicators of retail location. Thus, courts and commentators again found infringement doctrine lacking and often relied on dilution to prevent the substantial impairment of the location function by cybersquatters and parasitic metatags. ${ }^{39}$ At the same time, however, a new expansion of consumer confusion is underway with the passage of the Anticybersquatting Consumer Protection Act (ACPA) and the rise of "initial interest confusion" doctrine. ${ }^{40}$

MINN. L. REV. 693, 732-33 (1997).

35. See, e.g., Klieger, supra note 9, at 810 ("Judged in its historical context, Schechter's dilution proposal is best understood as a dramatic reaction to the inability or unwillingness of courts and legislatures to reform trademark law in light of the post-Industrial Revolution trade explosion."). From this Klieger draws the conclusion that "ensuing reforms [to consumer confusion] . . . quickly deprived dilution of any legitimate role in modern trademark law." Id. As this analysis will demonstrate, Klieger overstates his strong case against the broad application of dilution statutes.

36. To see how this interpretation explains the development of trademark "tarnishment" law, see infra Part V.A-B.

37. See Schecter, supra note 1, at 814-16.

38. See Ringling Bros.-Barnum \& Bailey Combined Shows, Inc. v. Utah Div. of Travel Dev., 170 F.3d 449, 454 (4th Cir. 1999), cert. denied, 528 U.S. 923 (1999); Bannon, supra note 10, at 69, 86-87; Klieger, supra note 9, at 80205 ; Schechter, supra note 1, at 816.

39. See, e.g., Golinveaux, supra note 26, at 654-68 (explaining the development and expansion of dilution as courts have applied it to cybersquatter cases).

40. See Anticybersquatting Consumer Protection Act of 1999, Pub L. No. 106-113, 113 Stat. 1501A-545; Sporty's Farm L.L.C. v. Sportsman's Market, Inc., 202 F.3d 489, 497-98 (2d Cir. 2000), cert. denied, 120 S. Ct. 2719 (2000); Brookfield Communications, Inc. v. West Coast Entm't Corp., 174 F.3d 1036, 1062-64 (9th Cir. 1999). 
Part I of this Article analyzes the current struggle between infringement and dilution. Part II returns to the founding of dilution and rejects Schechter's broad formulation after probing both his original proposal and the puzzles of dilution doctrine. Part III reinterprets Schechter's idea as a remedy against infringement obsolescence, and then places this construction within the wider debate on fixing outdated laws. Parts IV and $\mathrm{V}$ provide support for an obsolescence reading of dilution and offer guidance on how to interpret the FTDA. Part VI examines the alteration of marks into location symbols by the Internet and dilution's subsequent revival.

\section{THE TANGLED THREADS OF TRADEMARK}

Trademark law has been a leading showcase for the great common law judges. ${ }^{41}$ This Part enters that arena and explores the present state of trademark doctrine. After a review of the basics, the focus turns to the feud between infringement and dilution.

\section{A. INFRINGEMENT}

According to infringement theory, marks need protection because they provide consumers with valuable information about the characteristics of goods and services. ${ }^{42}$ Imagine what shopping would be like without marks. Years ago, a famous slogan told people "Don't Squeeze the Charmin," even though it was impossible to resist. If marks like Charmin were not around, however, we would have to squeeze the Charmin and everything else in order to make even the most mundane purchasing decisions. Since each product line would look identical to its competitors, there would be no way to figure out how worthwhile any item was without subjecting it to a thorough examination. In a world with marks, however, consumers can easily gauge a product's quality based on advertising or on the prior performance of items that bore the same mark. ${ }^{43}$ By low-

41. See, e.g., Abercrombie \& Fitch Co. v. Hunting World, Inc., 537 F.2d 4, 7 (2d Cir. 1976) (Friendly, J.); S.C. Johnson \& Son, Inc. v. Johnson, 175 F.2d 176, 177 (2d Cir. 1949) (L. Hand, C.J.); id. at 180 (Clark, J., dissenting); Triangle Publ'ns, Inc. v. Rohrlich, 167 F.2d 969, 970 (2d Cir. 1948) (A. Hand, J.); id. at 974 (Frank, J., dissenting).

42. See, e.g., Carter, supra note 33, at 761.

43. See id.; Klieger, supra note 9 , at 790. 
ering customer search costs in this fashion, marks greatly facilitate commercial transactions. ${ }^{44}$

Marks also encourage producers to invest in quality by ensuring that they will reap the benefit of a fine reputation. ${ }^{45}$ Without trademark protection, competitors could poach on the goodwill of a firm by putting that firm's mark on their own goods. For instance, if every company that produced soft drinks could place "Coca-Cola" on its bottles, some sales that ordinarily go to Coca-Cola would be diverted to others freeriding on Coca-Cola's mark. This would make it less likely that a successful firm like Coca-Cola would want to mark its products. And without marks, blue-chip companies would be unable to recover an investment in quality goods because their items would be hard to distinguish from cheap knockoffs. A lack of trademark protection would therefore reduce the incentive for companies to pursue quality and leave consumers worse off. ${ }^{46}$

Infringement law recognizes these problems by offering protection against concurrent mark uses that could confuse consumers. As one might expect, infringement is the descendant of the common law action for "passing off" goods as those of another. ${ }^{47}$ Learned Hand once proclaimed that " $\left.t\right]$ he law of unfair trade comes down very nearly to this-as judges have repeated again and again-that one merchant shall not divert customers from another by representing what he sells as emanating from the second."48 Infringement doctrine thus holds that "a trademark owner has a property right only insofar as is necessary to prevent consumer confusion as to who produced the goods and to facilitate differentiation of the . . goods." 49

44. See Carter, supra note 33, at 762-63. See generally George J. Stigler, The Economics of Information, 69 J. POL. ECON. 213 (1961) (noting the difficulty in matching buyers and sellers due to search costs).

45. See Carter, supra note 33, at 762-63; William M. Landes \& Richard A. Posner, Trademark Law: An Economic Perspective, 30 J.L. \& ECON. 265, 26970 (1987).

46. See Carter, supra note 33, at 762-63 (noting that higher consumer search costs would result if companies lose the incentive to mark their goods).

47. See id. at 764.

48. Yale Elec. Corp. v. Robertson, 26 F.2d 972, 973 (2d Cir. 1928) (L. Hand, J.).

49. International Order of Job's Daughters v. Lindeburg \& Co., 633 F.2d 912, 919 (9th Cir. 1980). Trademark property rights differ significantly from those created by patent and copyright law. See infra text accompanying notes 156-59. 
Thus, the core of every infringement suit is the likelihood of consumer confusion. ${ }^{50}$ Under Judge Henry J. Friendly's formulation in Polaroid Corp. v. Polarad Electronics Corp., ${ }^{51}$ courts typically consider eight factors to determine whether a likelihood of confusion exists in a given case: (1) the strength of the senior mark; (2) the degree of similarity between the junior and senior uses; (3) the proximity of the products; (4) the likelihood that that the senior user will "bridge the gap"; (5) actual confusion; (6) the defendant's good faith in adopting the mark; (7) the quality of the defendant's product; and (8) the sophistication of the product's consumers. ${ }^{52}$

While many of these factors are self-explanatory, a few merit additional discussion. .3 The strength or distinctiveness of a mark refers to its ability to identify a product as coming from the mark owner. ${ }^{54}$ Marks are classified in categories of increasing distinctiveness: (1) generic; (2) descriptive; (3) suggestive; (4) arbitrary; and (5) fanciful. ${ }^{55}$ The more distinctive a mark, the more protection it usually receives. ${ }^{56}$ The proximityof-goods factor looks at how related the relevant products are. ${ }^{57}$ For example, the use of a similar mark on pancake mix and syrup is more likely to confuse consumers than the use of the same mark on pancake mix and lumber. ${ }^{58}$ Finally, "bridging

50. See, e.g., 15 U.S.C. § 1114(1); E. \& J. Gallo Winery v. Gallo Cattle Co., 967 F.2d 1280, 1290 (9th Cir. 1992) (citation omitted).

51. 287 F.2d 492 (2d Cir. 1961) (Friendly, J.).

52. See id. at 495 . On the definition of junior and senior users, see supra note 23.

53. The factor focusing on the quality of the defendant's product is an important element in the development of trademark infringement and dilution, as is discussed in Parts IV and V.

54. See, e.g., Brookfield Communications, Inc. v. West Coast Entm't Corp., 174 F.3d 1036, 1058 (9th Cir. 1999).

55. See Abercrombie \& Fitch Co. v. Hunting World, Inc., 537 F.2d 4, 9 (2d Cir. 1976) (Friendly, J.). Fanciful, arbitrary, and suggestive marks are considered "inherently distinctive" and therefore entitled to protection. See Melissa R. Gleiberman, Note, From Fast Cars to Fast Food: Overbroad Protection of Product Trade Dress Under Section 43(a) of the Lanham Act, 45 STAN. L. REV. 2037, 2041 (1993). Descriptive marks can obtain protection only if they have acquired distinctiveness (also called secondary meaning) through use in commerce. See Two Pesos, Inc. v. Taco Cabana, Inc., 505 U.S. 763, 769 (1992). The final category of marks-generic-receives no protection. See id. at 768.

56. See Abercrombie \& Fitch Co., 537 F.2d at 9.

57. As explained in Part IV.A-B, the junior and senior users need not be in direct competition for an infringement action to succeed.

58. See, e.g., Aunt Jemima Mills Co. v. Rigney \& Co., 247 F. 407, 409-10 (2d Cir. 1917). 
the gap" is a term of art that focuses on the probability that the senior user will eventually enter into direct competition with the junior user. 59

\section{B. DILUTION}

The second approach to trademark protection is dilution, which is concerned with safeguarding the advertising power of marks ${ }^{60}$ In a modern economy, companies often spend huge sums on making their brand names attractive to the public. As Ralph S. Brown, Jr. once famously observed, a mark "is a narrow bridge over which all the traffic powered by [product] advertising must pass .... With time, the symbol comes to be more than a conduit through which the persuasive power of advertising is transmitted, and acquires a potency, a 'commercial magnetism,' of its own."61 So while a mark like Nike undoubtedly identifies particular products, Nike's extraordinary value stems from the commercial power that extensive advertising (helped along by a few athletes) gives to the mark. ${ }^{62}$

Supporters of dilution contend that marks deserve protection due to their persuasive ability to sell goods. ${ }^{63}$ As a result, dilution theory posits that any concurrent use of a mark that can diminish its advertising power should be barred, even if

59. See, e.g., Nikon Inc. v. Ikon Corp., 987 F.2d 91, 95 (2d Cir. 1993).

60. See, e.g., I.P. Lund Trading ApS v. Kohler Co., 163 F.3d 27, 36 (1st Cir. 1998). Arguably, there is a third category of trademark protection. Congress has granted some organizations a monopoly-enforceable by criminal and civil penalties - over their marks. See San Francisco Arts \& Athletics, Inc. v. United States Olympic Comm., 483 U.S. 522, 532 n.8 (1987) (listing statutes granting such rights to the American National Red Cross, the 4-H Club, Smokey Bear, Woodsy Owl, the Daughters of the American Revolution, the Boy Scouts, the Girl Scouts, and Little League Baseball); Hughes, supra note 31, at 971-72 (discussing the special protection given to cultural symbols).

61. Brown, supra note 16 , at 1187.

62. As Justice Felix Frankfurter once explained,

If it is true that we live by symbols, it is no less true that we purchase goods by them. A trade-mark is a merchandising short-cut which induces a purchaser to select what he wants, or what he has been led to believe he wants. The owner of a mark exploits this human propensity by making every effort to impregnate the atmosphere of the market with the drawing power of a congenial symbol.

Mishawaka Rubber \& Woolen Mfg. Co. v. S.S. Kresge Co., 316 U.S. 203, 205 (1942).

63. See Bannon, supra note 10 , at 90 (noting that dilution statutes protect a mark's commercial value); Welkowitz, supra note 10, at 533 (explaining that Schecter thought the real value protected by a trademark was its advertising power). 
that use could not confuse consumers. ${ }^{64}$ Schechter described the idea before a congressional committee: "[T]ake Rolls Royce-for instance, if you allow Rolls Royce restaurants and Rolls Royce cafeterias, and Rolls Royce pants, and Rolls Royce candy, in 10 years you will not have the Rolls Royce mark any more."65 What Schechter meant was that even if people would not confuse Rolls Royce pants with Rolls Royce cars, a proliferation of Rolls Royce products unaffiliated with the original mark would still injure the mark's advertising magnetism. Since dilution focuses on the marks themselves rather than on consumers, the concept is characterized as more akin to trespass than to consumer protection law. ${ }^{66}$

Until recently, dilution was a creature of state law. ${ }^{67}$ About half of the states have enacted dilution statutes, and most of those were patterned on the Model State Trademark Act, which provides,

Likelihood of injury to business reputation or of dilution of the distinctive quality of a mark registered under this Act, or a mark valid at common law, or a trade name valid at common law, shall be a ground for injunctive relief notwithstanding the absence of competition between the parties or the absence of confusion as to the source of goods or services. ${ }^{68}$

To prevail in a state dilution action, mark owners usually need to show (1) that the mark is truly distinctive or has acquired secondary meaning, and (2) that there exists a likelihood of dilution. ${ }^{69}$

64. See Bannon, supra note 10, at 92 (quoting Judge Learned Hand regarding the dangers of dilution); Schechter, supra note 1, at 831 (noting that the selling power of a trademark is based on its uniqueness); Welkowitz, supra note 10, at 533-34 (explaining that Schecter was critical of trademark protection limitations on non-competing goods).

65. Hearings Held Before the House Comm. on Patents, 72d Cong., 1st Sess. 15 (1932) (statement of Frank I. Schechter). Schechter's argument for dilution is examined more closely in Part II.

66. See 4 MCCARTHY, supra note 10, \& 24:90; Kristine M. Boylan, The Corporate Right of Publicity in Federal Dilution Legislation, 81 J. PAT. \& TRADEMARK OFF. SOC'Y 815, 819 (1999).

67. See Welkowitz, supra note 10, at 536-37.

68. MODEL STATE TRADEMARK BILL § 12 (1964), reprinted in 3 MCCARTHY, supra note $13, \S 22: 8$, cited in Ringling Bros.-Barnum \& Bailey Combined Shows, Inc. v. Utah Div. of Travel Dev., 170 F.3d 449, 456 (4th Cir. 1999), cert. denied, 528 U.S. 923 (1999); Welkowitz, supra note 10, at 536-37 (quoting the anti-dilution provision of the Model State Trademark Act).

69. See, e.g., Deere \& Co. v. MTD Prods., Inc., 41 F.3d 39, 42 (2d Cir. 1994) (applying New York law); Hyatt Corp. v. Hyatt Legal Servs., 736 F.2d 1153, 1157 (7th Cir. 1984) (applying Mlinois law); Pignons S.A. de Mecanique de Precision v. Polaroid Corp., 657 F.2d 482, $494-95$ (1st Cir. 1981) (applying 
Thus, one difference between dilution and infringement is that dilution covers only a limited class of marks that possess significant inherent distinctiveness or secondary meaning, while infringement is a remedy available for all valid marks. The distinctiveness requirement for dilution stems from the notion that weak marks "are [already] saturated and already diluted."70 Another way of putting this is that weak marks do not possess much persuasive power because they are either comprised of terms that are used on all sorts of products or are just not recognized by many people. ${ }^{71}$ Weak marks, therefore, do not ordinarily merit dilution protection because they are not really worth copying. ${ }^{72}$

Two harms are identified as dilution under state law: "the blurring of a mark's product identification or the tarnishment of the affirmative associations a mark has come to convey."73 Blurring occurs when "the defendant uses or modifies the plaintiff's trademark to identify the defendant's goods and services, raising the possibility that the mark will lose its ability to serve as a unique identifier of the plaintiffs product."74 By contrast, “' $[t]$ arnishment' generally arises when the plaintiff's trademark is linked to products of shoddy quality, or is portrayed in an unwholesome or unsavory context likely to evoke unflattering thoughts about the owner's product[s]."75 Both of

Massachusetts law).

70. See Bannon, supra note 10, at 100. Some have pushed for the elimination of the distinctiveness prong on the ground that weak marks are more susceptible to dilution than strong marks. See Welkowitz, supra note 10, at 540; infra text accompanying notes 166-67.

71. There are marks comprised of generic terms that have acquired secondary meaning and become quite strong. One example is General Motors, which contains words used in many brand names, but still identifies an established set of products.

72. A direct competitor of a firm with a weak mark might still want to copy the mark to injure that specific firm, but that kind of harm would normally be covered by infringement.

73. Deere, 41 F.3d at 42; see also Note, supra note 10, at 531 (quoting Mead Data Cent., Inc. v. Toyota Motor Sales, U.S.A., Inc., 875 F.2d 1026, 1031 (2d Cir. 1989)). Courts have been unable to reach a consensus on how to analyze blurring and tarnishment claims. For more on the chaotic state of dilution doctrine, see Part II.D.2.

74. Deere, 41 F.3d at 43; see Ringling Bros.-Barnum \& Bailey Combined Shows, Inc. v. Celozzi-Ettelson Chevrolet, Inc., 855 F.2d 480, 485 (7th Cir. 1988) (finding that "The Greatest Show on Earth" was blurred by "The Greatest Used Car Show on Earth").

75. Deere, 41 F.3d at 43; see also Cmty. Fed. Sav. \& Loan Ass'n v. Orondorff, 678 F.2d 1034, 1037 (11th Cir. 1982) (holding that the use of "Cookie Jar" by a topless dance bar tarnished the mark of a savings and loan). Tar- 
these dilution harms, of course, are actionable only if the mark is strong or distinctive.

Decades of futile effort to enact a federal dilution remedy ended with the passage of the FTDA in the mid-1990s. ${ }^{76}$ The FTDA defined dilution as "the lessening of the capacity of a famous mark to identify and distinguish goods or services, regardless of the presence or absence of competition, likelihood of confusion, mistake, or deception."77 Although the statute's legislative history is scanty, ${ }^{78}$ Congress apparently concluded that a federal dilution law was necessary because "famous marks ordinarily are used on a nationwide basis and dilution protection is currently available on a patch-quilt system of protection, in that only approximately twenty-five states have laws that prohibit trademark dilution."79 The FTDA provides, in pertinent part, that "[t]he owner of a famous mark shall be entitled, ... to an injunction against another person's commercial use in commerce of a mark or trade name, if such use begins after the mark has become famous and causes dilution of the distinctive quality of the mark." 80 This novel federal remedy was enacted with overwhelming support.

Thus, the primary elements of a federal dilution claim are (1) fame, (2) commercial use, and (3) dilution. ${ }^{81}$ The fame re-

nishment can raise serious First Amendment questions by chilling commercial speech or parodies of well-known marks. See L.L. Bean, Inc. v. Drake Publishers, Inc., 811 F.2d 26, 33-34 (1st Cir. 1987) (holding the Maine antidilution statute unconstitutional on this basis). While these kinds of First Amendment issues are worth exploring, this analysis strives to avoid constitutional difficulties and focuses instead on tarnishment's role within the trademark regime.

76. Schechter led the first unsuccessful attempt to pass a federal dilution law in 1932. See Ringling Bros.-Barnum \& Bailey Combined Shows, Inc. v. Utah Div. of 'Travel Dev., 170 F.3d 449, 454 n.2 (4th Cir. 1999), cert. denied, 528 U.S. 923 (1999). In 1988, a dilution provision passed the Senate but was not taken up by the House of Representatives. See I.P. Lund Trading ApS v. Kohler Co., 163 F.3d 27, 46 \& n.10 (1st Cir. 1998).

77. 15 U.S.C. $\S 1127$ (Supp. IV 1999).

78. The FTDA was passed without any hearings in the Senate and only a few in the House. See 4 MCCARTHY, supra note 10, $\$ 24: 87$. Some courts have relied on the more extensive legislative history of the unsuccessful $1988 \mathrm{dilu}$ tion provision to interpret the FTDA. See I.P. Lund, 163 F.3d at 46 \& n.10. Using legislative history from a bill that failed seven years prior to the FTDA's enactment, however, is highly dubious.

79. H.R. REP. NO. 104-374, at 3 (1995).

80. 15 U.S.C. $\S 1125$ (c)(1) (Supp. IV 1999). The FTDA contains exceptions for (1) fair use of a trademark in comparative advertising, (2) non-commercial uses of a mark, and (3) news reporting and commentary. See id. $\S 1125(c)(4)$.

81. Avery Dennison Corp. v. Sumpton, 189 F.3d 868, 874 (9th Cir. 1999). 
quirement is analogous to the state law principle that a mark must be particularly distinctive to get dilution protection. ${ }^{82}$

The Second Circuit has held that the FTDA requires a mark to be distinctive as well as famous to receive dilution protection. Nabisco, Inc. v. PF Brands, Inc., 191 F.3d 208, 215 (2d Cir. 1999). This conclusion is based on language in the statute indicating that only "famous and distinctive" marks are covered. See id. (citing 15 U.S.C. $\$ 1125(c)(1))$. One leading commentator argues that the inclusion of a separate distinctiveness element in the FTDA was a drafting error and is redundant given that the statute only protects famous marks. See 4 MCCARTHY, supra note $10, \S 24: 91$. That view, however, was expressly rejected by the Second Circuit. See Nabisco, 191 F.3d at 216 n.2.

The Second Circuit's construction is more consistent with the text of the FTDA. On the other hand, the court in Nabisco appears to have interpreted distinctive to mean inherently distinctive. The opinion provides examples of famous marks, such as American Airlines and Allied Stores, that are not inherently distinctive and hence would not be eligible for dilution relief. Id. at 227-28. Both of these marks, however, have acquired distinctiveness (i.e., secondary meaning) through use in commerce and are distinctive in that sense. Famous marks with secondary meaning may deserve less protection than famous and inherently distinctive marks, see Abercrombie \& Fitch Co. v. Hunting World, Inc., 537 F.2d 4, 9 (2d Cir. 1976) (Friendly, J.), but Nabisco says that famous marks without inherent distinctiveness should get no dilution protection at all, $\mathrm{Nabisco,} 191 \mathrm{~F} .3 \mathrm{~d}$ at 219.

Nabisco does not explain why the term "distinctive" in the FTDA ought to be construed as encompassing only inherently distinctive marks. The construction is particularly odd given that the statute's fame prong refers explicitly to "inherent or acquired distinctiveness." 15 U.S.C. $\S 1125(\mathrm{c})(1)(\mathrm{A})$. Interpreting distinctive to include acquired and inherent distinctiveness, however, would render the term distinctive in the statute meaningless, since a mark cannot be famous without having at least some acquired distinctiveness. Perhaps the phrase "famous and distinctive" should be read as a single term of art-whether the product of a drafting error or not-rather than as establishing separate fame and distinctiveness elements. See Times Mirror Magazines, Inc. v. Las Vegas Sports News, L.L.C., 212 F.3d 157, 166-67 (3rd Cir. 2000), cert. denied, No. 00-470, 2001 WL 12465 (Jan. 8, 2001).

82. The FTDA states,

In determining whether a mark is distinctive and famous, a court may consider factors such as, but not limited to-

(A) the degree of inherent or acquired distinctiveness of the mark;

(B) the duration and extent of use of the mark in connection with the goods or services with which the mark is used;

(C) the duration and extent of advertising and publicity of the mark;

(D) the geographical extent of the trading area in which the mark is used;

(E) the channels of trade for the goods or services with which the mark is used;

(F) the degree of recognition of the mark in the trading areas and channels of trade used by the marks' owner and the person against whom the injunction is sought;

(G) the nature and extent of use of the same or similar marks by third parties; and

$(\mathrm{H})$ whether the mark was registered under the [trademark statutes]. . . . 
Commercial use of a mark is necessary to provide a federal nexus, under the Commerce Clause, for a dilution remedy. ${ }^{83}$ Finally, as for the dilution component itself, the FTDA has been read to incorporate the blurring and tarnishment theories without being limited to the state law paradigms. ${ }^{84}$

\section{CONFLICT BETWEen THE TRADEMARK MODELS}

While infringement and dilution both aspire to protect trademarks, they obviously take a quite different view of why marks are worth protecting. In the eyes of infringement law, marks grant owners a limited property right to help consumers distinguish goods. Infringement supporters acknowledge that marks have persuasive power, and concede that protecting marks for the benefit of consumers may indirectly protect advertising magnetism. ${ }^{85}$ They contend, however, that safeguarding persuasive power itself should not be a goal of trademark doctrine because that would grant mark owners an unwarranted monopoly. ${ }^{86}$ Dilution, of course, takes the opposite tack. Its advocates assert that marks are worth protecting because their owners have gone to great lengths to make them commercially attractive, and that the resulting benefits to consumers are incidental. ${ }^{87}$

What makes the joust between infringement and dilution more than an ordinary doctrinal dispute is that the only stable equilibrium between the two models lies in the triumph of one over the other. Although dilution is often described as starting where the likelihood of confusion test leaves off, it is more accu-

15 U.S.C. $\S 1125(\mathrm{c})(1)$.

Before determining what marks should get dilution protection, we need to understand what dilution means. It should be said, however, that as a practical matter the fame or distinctiveness determination in dilution cases has almost always turned on whether the mark at issue needed transitional protection due to infringement obsolescence. This highly pragmatic view of what is a famous mark has been carried over into the FTDA, which permits courts to examine a wide range of evidence in making a fame determination.

83. Cf. The Trademark Cases, 100 U.S. 82, 94, 97-98 (1879) (holding that Congress has no power to regulate marks pursuant to the Patent and Copyright Clauses).

84. See Panavision Int'l v. Toeppen, 141 F.3d 1316, 1326 (9th Cir. 1998); 4 MCCARTHY, supra note $10, \S 24.90$.

85. See Brown, supra note 16, at 1189-90; Klieger, supra note 9, at 793.

86. See RESTATEMENT, supra note 17, § $25 \mathrm{cmt}$. b; Brown, supra note 16, at 1190; Klieger, supra note 9, at 851-52.

87. See, e.g., Klieger, supra note 9, at 851 n.369. 
rate to say that infringement follows a fortiori from dilution. ${ }^{88}$ While dilution theory posits that there are many uses of a mark that harm its persuasive power without risking consumer confusion, there is little doubt that "if a consumer mistakenly believes that Company B's goods are made, sponsored, or approved by Company A, then to the confused consumer, the value of Company A's mark with respect to that consumer is [diluted]."89 It is almost impossible to think of any infringement situation that would not be covered by dilution.

This raises the following question: why do we need infringement for the marks covered by dilution? ${ }^{90}$ Since dilution doctrine encompasses all possible infringement cases, infringement starts to look as useless as the human appendix. ${ }^{91}$ Accordingly, the leading modern critic of dilution, Robert $N$. Klieger, believes that "[i]t may just be a matter of time before dilution eclipses confusion as the gravaman of most federal

88. See, e.g., Nabisco Brands, Inc. v. PF Brands, Inc., 191 F.3d 208, 219 (2d Cir. 1999) ("Consumer confusion would undoubtedly dilute the distinctive selling power of a trademark."); James Burrough, Ltd. v. Sign of Beefeater, Inc., 540 F.2d 266, 274 n.16 (7th Cir. 1976) (stating that dilution necessarily follows from consumer confusion); Klieger, supra note 9, at 812 (stating that "[an] antidilution statute, read literally, render[s] the consumer confusion test immaterial").

Supporters of dilution strenuously object to the argument that dilution necessarily follows from confusion. They maintain that dilution and infringement are different theories "positing a different kind of damage to a mark caused by a different form of consumer conception." 4 MCCARTHY, supra note $10, \S 24: 71$. That analysis is conceptually flawed and has been uniformly rejected by the case law. See, e.g., Ringling Bros.-Barnum \& Bailey Combined Shows, Inc. v. Celozzi-Ettelson Chevrolet, Inc., 855 F.2d 480, 484 (7th Cir. 1988). Moreover, no court has ever found a likelihood of consumer confusion and then not also found dilution for a mark that was eligible for dilution protection.

89. Welkowitz, supra note 10, at 548; see also, e.g., Duffey, supra note 15, at 149 ("The elements required to establish a trademark infringement claim will likely suffice to establish a prima facie case under the FTDA." (citation omitted)).

90. See, e.g., RESTATEMENT, supra note $17, \S 25 \mathrm{cmt}$. b; Welkowitz, supra note 10 , at 546 ("Courts have expressed reservations that a stringent application of antidilution statutes would swallow up much of the law of trademark and unfair competition...."); Note, supra note 10, at 529 (stating that a proper dilution remedy would allow courts to dispense with most infringement and unfair competition doctrine).

91. One way to mitigate the conflict between infringement and dilution would be to make infringement the sole remedy for disputes between competitors, while confining dilution to claims involving non-competing goods. See Pro-Phy-Lac-Tic Brush Co. v. Jordan Marsh Co., 165 F.2d 549, 553 (1st Cir. 1948). This idea, however, has never gained any support. E.g., Nabisco, 191 F.3d at 222-23. 
trademark actions and trademark rights in gross displace consumer protection as the defining feature of United States trademark law."92 Infringement backers like Klieger basically have one response to this doomsday scenario: dilution must be destroyed. ${ }^{93}$

Maybe the situation is not so dire. After all, dilution is only available for famous or quite distinctive marks. So in theory, a zero-sum struggle between the trademark protection models involves only some marks. ${ }^{94}$ The difficulty with this easy answer is that courts have been quite willing to declare many weak marks famous or distinctive enough to come within dilution's grasp. ${ }^{95}$ Some examples include the following: (1) the "Candy Land" board game; (2) the Maryland "Gazette" newspaper chain; (3) "Wawa" convenience stores; and (4) "Wedgewood" homes. ${ }^{96}$ The breadth of the marks in this clutch of cases does not engender confidence in the ability of the distinctiveness element to ease the conflict between dilution and infringement. ${ }^{97}$ Moreover, some courts have extended dilution protection without making a fame or distinctiveness finding at all. ${ }^{98}$

Even if the restriction of dilution to a subset of marks is meaningful, however, the Darwinian struggle between infringement and dilution remains an issue for a substantial number of marks.

Besides, a narrow reading of what constitutes a famous mark is really just another way for infringement advocates to wipe out dilution. As discussed in Part II.C, strong (i.e., fa-

92. Klieger, supra note 9, at 847-48 (footnote omitted).

93. See id. at 865-66; Welkowitz, supra note 10 , at 587-88.

94. See Avery Dennison Corp. v. Sumpton, 189 F.3d 868, 875 (9th Cir. 1999) (stating that the fame prong preserves the proper balance between public and private rights).

95. See Klieger, supra note 9, at 848-49; Lemley, supra note 17, at 1698.

96. See Wedgewood Homes, Inc. v. Lund, 659 P.2d 377, 380 (Or. 1983); Klieger, supra note 9, at 849-51; Lemley, supra note 17, at 1698.

97. See Klieger, supra note 9 , at 851 . Some of the cases in which the definition of fame has been stretched involve the Internet. See, e.g., Jews for Jesus v. Brodsky, 993 F. Supp. 282, 305-06 (D.N.J. 1998) (finding "Jews for Jesus" famous); Hasbro, Inc. v. Internet Entm't Group, Ltd., 40 U.S.P.Q.2d (BNA) 1479,1480 (W.D. Wash. 1996) (finding "Candyland" famous); $c f$. Sporty's Farm L.L.C. v. Sportsman's Mkt, Inc., 202 F.3d 489, 497 (2d Cir. 2000) (stating that the new Anticybersquatting statute "was adopted specifically to provide courts with a preferable alternative to stretching federal dilution law when dealing with cybersquatting cases"). To see why courts might strain to extend dilution to the Internet, see infra Part VI.A.

98. See Lemley, supra note 17, at 1698-99 \& n.51. 
mous) marks are already protected from virtually all concurrent uses by infringement doctrine, and therefore dilution extends no additional protection unless the definition of fame is construed liberally. ${ }^{99}$ By urging a narrow interpretation of fame, infringement backers were essentially trying to render dilution law superfluous.

Failing in their effort to prevent the enactment of dilution statutes, pro-infringement forces retreated to the courts and pleaded for dilution to be read as narrowly as possible. ${ }^{100}$ Many judges obliged by employing quite creative (or strained) interpretations of dilution laws. ${ }^{101}$ Some imposed a likelihood of consumer confusion requirement on dilution plaintiffs in spite of explicit statutory language to the contrary. 102 Others added an extra element to dilution by holding that defendants must have had a predatory intent for a dilution action to succeed. ${ }^{103}$ The Fourth and Fifth Circuits have recently tried another approach by construing the FTDA to require proof of actual dilution, even though "concededly [this] is a stringent interpretation of 'dilution' in the Federal Act."104 Dilution supporters

99. See Klieger, supra note 9, at 846-47; Litman, supra note 11 , at 1724 $\mathrm{n} .44$; infra text accompanying notes 163-67 (discussing the superfluous nature of dilution).

100. See, e.g., Welkowitz, supra note 10, at 588 ("If legislatures cannot summon the will to repeal dilution statutes, the statutes should be limited as much as their language will permit.").

101. See Boylan, supra note 66 , at 816 ("C $[$ C]ourts had declined to enforce the statutes literally; they restricted dilution protection in various ways that the statutory language simply did not support."); Klieger, supra note 9 , at 819 ("Whatever the approach of a particular court, the 'plain, literal language' of the antidilution statutes was universally ignored, and the dilution cause of action thoroughly 'emasculated,' in case after case." (footnote omitted)).

102. See Esquire, Inc. v. Esquire Slipper Mfg. Co., 243 F.2d 540, 542-43 (1st Cir. 1957); Cue Publ'g Co. v. Colgate-Palmolive Co., 256 N.Y.S.2d 239, 243-44 (N.Y. Sup. Ct. 1865), affd, 259 N.Y.S.2d 377 (N.Y. App. Div. 1965); RESTATEMENT, supra note 17, § $25 \mathrm{cmt}$. b; Klieger, supra note 9, at 817-18.

103. See Klieger, supra note 9, at 818-19; Laura M. Slenzak, Dilution Law in the United States and Canada: A Review of the State of the Law and a Proposal for United States Federal Dilution Protection, 83 TRADEMARK REP. 205, 215 (1993). A predatory intent requirement does not make much sense. Most of the time, someone who copies a famous mark does not want to injure that mark. Damaging the famous mark only diminishes its value and limits what the putative dilutor can reap through copying.

104. Ringling Bros.-Barnum \& Bailey Combined Shows, Inc. v. Utah Div. of Travel Dev., 170 F.3d 449, 458, 461 n.6 (4th Cir. 1999), cert. denied, 528 U.S. 923 (1999); Westchester Media, L.L.C. v. PRL USA Holdings, Inc., 214 F.3d 658, 670-71 (5th Cir. 2000). But see Nabisco, Inc. v. PF Brands, Inc. 191 F.3d 208, 223-25 (2d Cir. 1999). 
have understandably howled in protest at being on the losing end of the judicial "firmness in insulating the common law of unfair competition from the dilution doctrine." 105

The two trademark models appear headed for a wrestling match over the Reichenbach Falls. ${ }^{106}$ Under the conventional view, dilution will either supersede infringement or courts will save infringement by interpreting dilution in a highly restrictive fashion. To avoid this harsh choice, we must reconstruct the relationship between infringement and dilution.

\section{ON THE ORIGIN OF DILUTION}

This Part sifts through Schechter's original argument for dilution in the pages of the Harvard Law Review. ${ }^{107}$ In response to the change of marks into quality indicators by the Industrial Revolution, Schechter contended that the consumer confusion model of trademark protection should be abandoned. His rationale for dilution has not only been heavily criticized by commentators, but it fails to explain many aspects of modern dilution doctrine. Meeting both of these challenges requires us to discard Schechter's explanation and re-imagine his proposal as a remedy for infringement obsolescence.

\section{A. FROM SOURCE TO QUALITY}

Before Schechter achieved fame through dilution, he made a critical contribution to trademark law by pointing out the transformation of marks from source identifiers into quality symbols. ${ }^{108}$ Marks got their start as a requirement imposed by medieval guilds and towns to identify smuggled goods, which would not have an approved mark, and the producers of shoddy goods, who would be subject to discipline. 109 To understand how the development of a modern economy changed the function of marks and spurred Schechter to invent dilution, we must start by examining how people shopped in olden days.

105. Note, supra note 10 , at 528; see also Pattishall, supra note 21 , at 628 (stating that courts had "relegated [dilution] to the legal junk yard").

106. See Arthur Conan Doyle, The Final Problem, in THE ORIGINAL ILLUSTRATED SHERLOCK HOLMES 327, 337 (Castle n.d.) (describing the final duel between Sherlock Holmes and his archenemy, Professor Moriarty).

107. See generally Schecter, supra note 1.

108. See Bannon, supra note 10, at 69-70; Klieger, supra note 9, at 801-02; Schechter, supra note 1 , at 816.

109. See Schechter, supra note 1 , at 814. 


\section{Horse-and-Buggy Commerce}

During the pre-industrial era, consumers bought goods mainly from local producers that were well known to them. This mode of consumption evolved because transportation was quite limited, and local craftsmen possessed a significant advantage over their more distant competitors. These local manufacturers were also generally small and sold only one type of good. ${ }^{110}$ Remember that the modern corporation capable of organizing large-scale production for different items only began to emerge in the late nineteenth century. To illustrate how these commercial realities shaped trademark doctrine, let us call the paradigmatic mark owner during this period "Spark the Blacksmith."

Under an agrarian economic regime, Spark's mark identified the source of his goods.111 In other words, when customers went to a store to look for small manufactured items, they distinguished Spark's horseshoes or nails from those made by other blacksmiths by finding his mark. ${ }^{112}$ The recognition that products were forged by Spark was significant because consumers knew who Spark was and were therefore aware of his particular reputation for producing quality goods. By marking his items, Spark "maintained the identity of [his] product through the hands of the middleman" and preserved a direct link with his customers. ${ }^{113}$

The predominance of mom-and-pop production, however, meant that marks could serve only a limited role in commercial life. Outside the local area, Spark's mark would not say anything about the source of the marked goods. This was because nobody would have heard of Spark, not to mention that other blacksmiths named Spark-with different reputationsprobably worked elsewhere. Furthermore, the use of Spark's

110. See Klieger, supra note 9, at 796; Schechter, supra note 1, at 814 . This is not to say that there were no widely-known brand names at that time. In particular, certain luxury items like porcelain or jewels may well have been made by well-known craft firms. This constituted, however, only a small portion of commercial activity.

111. See, e.g., Brown, supra note 16, at 1185-87; Klieger, supra note 9, at 797-98.

112. Of course, many local producers sold their goods themselves rather than relying on a merchant. If Spark owned a store at his forge, then his mark-via a storefront sign-would indicate the retail location of his products. For more on the location-identifying function of marks, see infra Part VI.A.

113. Benjamin G. Paster, Trademarks-Their Early History, 59 TRADEMARK REP. 551, 552 (1969). 
mark by producers of other kinds of items would not create a problem. Everyone who was aware of Spark's reputation knew that Spark was a blacksmith and not a butcher or a candlestick maker. Accordingly, nobody could be misled into thinking that goods marked "Spark" were made by Spark the Blacksmith unless those products were of a type ordinarily forged by blacksmiths.

The common law of unfair competition eventually developed the consumer confusion test to protect the sourceidentifying function of marks. ${ }^{114}$ Due to the relatively minor part marks played in trade, the scope of confusion doctrine was restricted in two major ways. First, a mark was shielded only "where [the] mark ha[d] significance-that is, only in the geographic market that it actually serve[d]."115 Thus, Spark could not stop manufacturers in other communities from using his mark unless he could make the unlikely showing that his mark was actually recognized there. ${ }^{116}$ Second, infringement relief was available only when the senior and junior users were direct competitors. ${ }^{117}$ Based on the assumption that each producer focused on a known and limited set of goods, the common law was clear: "If [the mark owner] does not carry on a trade in iron, but carries on a trade in linen and stamps a lion on his linen, another person may stamp a lion on iron."118 This narrow zone of protection for marks fit the commercial needs of the time.

\section{A Mechanical Age}

The pastoral world of the town craftsman was but a distant memory by the dawn of the twentieth century. Due to sweeping advances in transportation and production methods, consumers bought fewer goods from local manufacturers. 119 In-

114. Before the likelihood of confusion test emerged, an action for trademark deceit would only lie if there was an actual diversion of sales from the senior user to the junior user. See, e.g., Schechter, supra note 1, at 821.

115. Dawn Donut Co. v. Hart's Food Stores, Inc., 267 F.2d 358, 364 (2d Cir. 1959); see also Carter, supra note 33, at 790.

116. See, e.g., Dawn Donut, 267 F.2d at 364 (" $[1] f$ the use of the marks by the registrant and the unauthorized user are confined to two sufficiently distinct and geographically separate markets ... then the registrant is not entitled to enjoin the junior user's use of the mark.").

117. See Klieger, supra note 9, at 796; Litman, supra note 11, at 1724 n.41; Schechter, supra note 1 , at $820-22$.

118. Ainsworth v. Walmsley, L.R. 1 Eq. 518, 524-25 (1866).

119. See, e.g., Klieger, supra note 9 , at 799. 
stead, shoppers counted on corporations that used economies of scale to provide cheaper goods with more variety than ever before. This new consumption pattern radically altered the relationship between customers and producers. While a local entrepreneur like Spark was well known by his customers, they knew little about the corporate behemoths that now supplied their needs. ${ }^{120}$ Moreover, these firms were often conglomerates that produced many types of unrelated goods; an achievement well beyond the capabilities of a typical small business. ${ }^{121}$

This structural upheaval reshaped the economy and fundamentally altered the mark's source-identifying function. Although marks continued to designate the source of goods, that information was now worthless because corporate sources were basically anonymous. ${ }^{122}$ Shoppers do not usually know or care whether a certain kind of shampoo is made by Johnson \& Johnson or Proctor \& Gamble. They buy the shampoo because they think that the brand name-as distinct from the source-has a good reputation. ${ }^{123}$ But if consumers no longer knew much about the sources of their goods, then how did marks still serve a useful purpose?

Schechter answered that question by recognizing that marks had become important as abstract symbols of consistent quality. ${ }^{124}$ Imagine that the descendants of Spark decided to

120. See Brown, supra note 16 , at $1185-87$; Schechter, supra note 1 , at 814 ; see also Walter Baker \& Co. v. Slack, 130 F. 514, 518 (7th Cir. 1904) ("We may safely take it for granted that not one in a thousand knowing of or desiring to purchase 'Baker's Cocoa' or 'Baker's Chocolate' know of Walter Baker \& Co., Limited.").

121. See, e.g., Klieger, supra note 9, at 800; Edward C. Lukens, The Application of the Principles of Unfair Competition to Cases of Dissimilar Products, 75 U. PA. L. REV. 197, 204-05 (1927).

122. See Klieger, supra note 9, at 800; Schechter, supra note 1 , at 814 . Judge Learned Hand was one of the first to recognize the change in the source-identifying function when he said that "[i]t is, of course, not necessary, that [the mark owner] should be known as the maker; on the contrary, it will suffice if the article be known as coming from a single, though anonymous, source." Coty, Inc. v. LeBlume Import Co., 292 F. 264, 267-68 (S.D.N.Y. 1923), affd, 293 F. 344 (2d Cir. 1923).

123. See, e.g., Shredded Wheat Co. v. Humphrey Cornell Co., 250 F. 960, 963 (2d Cir. 1918); Brown, supra note 16, at 1185-86. Of course, marks in the modern economy also act as product identifiers (i.e., the product's name), but this adds little to trademark analysis. Distinctions between product lines (as opposed to brand names) involve only direct competitors, and therefore settled infringement doctrine should be able to address issues arising from potential product confusion.

124. See Bannon, supra note 10, at 66; see also Klieger, supra note 9, at 801-02 ("Judicial recognition of the quality representation function of trade- 
set up a company that produced tools, home accessories, and clothing with the Spark mark. Whereas "Spark" once evoked a known person in a single trade, the mark now told consumers that the product was made by the same anonymous source that supplied other goods with the Spark mark. In other words, a mark "assure[d] the public that the goods purchased today will be the same as the goods bearing the same trademark that were purchased yesterday."125 By providing this consistency guarantee, marks gave consumers confidence that Spark products would be similar in quality (good or bad) to previous items wearing the Spark label.

Even though marks created a consistent quality benchmark, consumers still had to gauge the reputation behind "Spark" to take advantage of the consistency that the mark represented. Rather than utilizing local knowledge as in the past, consumers now relied on advertising and on their own experience with Spark products to figure out what could be expected from items with that mark. No matter how shoppers formed their quality expectations, the key was that the mark ensured that those impressions-whether well informed or not-matched what appeared on the shelves. Marks had become commercial vessels designed "to identify a product as satisfactory and thereby to stimulate further purchases by the consuming public."126

The evolution of marks from source identifiers into quality indicators meant that "[ $t]$ he assumptions upon which nineteenth century trademark law were built did not match early twentieth century trade realities."127 In particular, the limitation of infringement protection to junior uses by direct competitors no longer made much sense. Under the regime of Spark the Blacksmith, consumers knew what kinds of things the local sources of their goods made. Marks therefore represented a reputation for quality that was limited to certain classes of goods and could not easily be appropriated by other kinds of producers.

marks, perhaps the most important development in trademark law this century, developed largely as a result of Schechter's proposal." (footnote omitted)).

125. Sidney A. Diamond, The Public Interest and the Trademark System, 62 J. PAT. \& TRADEMARK OFF. SOC'Y 528, 529 (1980).

126. Schechter, supra note 1 , at 818.

127. Klieger, supra note 9 , at 799-800. The development of national markets also meant that marks often needed protection over a wider area than in the past. 
In the brave new industrial world, however, consumers were well aware that a mark could show up on unrelated products coming from the same source. ${ }^{128}$ Marks represented a general reputation for quality that might be applied to many goods. ${ }^{129}$ As a result, stamping a mark on items unrelated to those made by the mark owner could mislead consumers into thinking that the junior user's goods were up to the quality standard symbolized by the mark. ${ }^{130}$ Put another way, junior uses of a mark, even by non-competitors, could substantially impair the quality-representing function by undermining a mark's consistency.

\section{Trademark Law Lags}

The sweeping changes ushered in by the Industrial Revolution were not matched by an equivalent leap in trademark doctrine. Well into this century, infringement had a tin ear when it came to the need for a new approach that would maintain the vitality of the mark's quality function. ${ }^{131}$ For instance, many courts stubbornly adhered to the view that consumer confusion was not possible when the junior and senior users were in different trades. ${ }^{132}$ Stirrings of reform were evident here and there, but as can sometimes be the case with the common law, these adjustments to longstanding doctrine were halting, factbound, and took a great deal of time. ${ }^{133}$

Much of Schechter's scholarly work poured withering scorn on the "failure of the courts to keep pace with the necessities of trade and the functional development of trademarks."134 His initial solution to the obsolescence problem was simply to expand the definition of consumer confusion. In his 1925 treatise, The Historical Foundations of the Law Relating to TradeMarks, Schechter argued that courts should acknowledge the impotence of source theory and celebrate the rise of the mark's

128. See id. at 800; Lukens, supra note 121, at 204-05.

129. See, e.g., Klieger, supra note 9 , at 803 .

130. See id.

131. See Brown, supra note 16, at 1195-98; Klieger, supra note 9, at 800-01;

Litman, supra note 11, at 1724 n.41.

132. See, e.g., Klieger, supra note 9 , at 800-01; Litman, supra note 11, at 1724 n. 41 .

133. See Aunt Jemima Mills Co. v. Rigney \& Co., 247 F. 407, 409-12 (2d Cir. 1917); Bannon, supra note 10 , at $68-69$; Klieger, supra note 9 , at 800 .

134. Schechter, supra note 1 , at 824 . 
quality function. ${ }^{135} \mathrm{He}$ then suggested modest reforms to the confusion test to protect that function. ${ }^{136}$

\section{B. The RATIONAL Basis OF TRADEMARK PROTECTION}

Schechter was not a patient man. Just two years after his treatise was published, he wrote The Rational Basis of Trademark Protection, which concluded that the consumer confusion model was hopelessly obsolete and should be replaced by dilution. ${ }^{137}$ Schechter described the modern trademark in poetic terms:

The signboard of an inn in stage-coach days, when the golden lion or the green cockatoo actually symbolized to the hungry and weary traveler a definite smiling host, a tasty meal from a particular cook, a favorite brew and a comfortable bed, was merely "the visible manifestation" of the good will or probability of custom of the house; but today the trademark is not merely the symbol of good will but often the most effective agent for the creation of good will, imprinting upon the public mind an anonymous and impersonal guaranty of satisfaction, creating a desire for further satisfactions. ${ }^{138}$

After reiterating that marks were now primarily quality indicators rather than source identifiers, Schechter launched yet another attack on the limited protection provided by infringement doctrine. He argued that a mark owner "should be allowed the broadest scope possible for 'the natural expansion of his trade' to other lines or fields of enterprise."139 In addition, he pointed out that "[ $t$ ] he use of similar marks on noncompeting goods is perhaps the normal rather than the exceptional case of infringement."140

The difference between Schechter's treatise and his subsequent article was that the latter argued that courts should focus on protecting the persuasive power given to marks by the

135. See Ringling Bros.-Barnum \& Bailey Combined Shows, Inc. v. Utah Div. of Travel Dev., 170 F.3d 449, 454 (4th Cir 1999), cert. denied, 528 U.S. 923 (1999); SCHECHTER, supra note 30, at 164-71; Klieger, supra note 9, at 801.

136. See Ringling Bros., 170 F.3d at 454; SCHECHTER, supra note 30, at 164-71; Klieger, supra note 9 , at 801.

137. See Ringling Bros., 170 F.3d at 454; Schechter, supra note 1, at 830 33. Although Schechter never actually used the word "dilution" to describe his proposal, he relied on several German dilution cases and thus his article has been construed as the genesis of dilution in American law.

138. Schechter, supra note 1 , at 818-19.

139. Id. at 823 .

140. Id. at 825 (alteration in original). 
quality function and advertising. ${ }^{141}$ As Schechter said, "To describe a trademark merely as a symbol of good will, without recognizing in it an agency for the actual creation and perpetuation of good will, ignores the most potent aspect of the nature of a trademark and that phase most in need of protection." ${ }^{142}$ He believed that by protecting investments in a mark's commercial magnetism "to the same extent as plant machinery," marks would get the optimal level of protection that infringement was unable to provide. ${ }^{143}$ In other words, while Schechter's treatise argued that the definition of consumer confusion was obsolete, his article contended that infringement itself was obsolete.

Based on this new approach to trademark protection, Schechter redefined the relevant injury as "the gradual whittling away or dispersion of the identity and hold upon the public mind of the mark or name by its use upon non-competing goods," which is now called dilution by blurring. ${ }^{144}$ He observed that it was self-evident that "the more distinctive the mark, the greater its selling power."145 A junior use was therefore harmful because it diminished the source of a mark's advertising power: its "arresting uniqueness."146 Furthermore, "[t]he more distinctive or unique the mark, the deeper is its impress upon the public consciousness, and the greater its need for protection against vitiation or dissociation from the particular product in connection with which it has been used."147

In essence, Schechter was articulating a classic commons problem long before that concept was invented. ${ }^{148}$ While a single junior use of a valuable resource (i.e., the persuasiveness of a distinctive mark) might well be innocuous, in the aggregate those uses could whittle away and destroy the resource unless they are adequately regulated. Marks are susceptible to this kind of exploitation because a mark owner cannot physically

141. See Ringling Bros., 170 F.3d at 454; Klieger, supra note 9, at 804-05.

142. Schechter, supra note 1 , at 818 .

143. Id. at 830. Although Schechter denied that he wanted to create property rights in gross though dilution, see id. at 822 , that was belied by his statement that marks should be protected like plant machinery.

144. Id. at 825 .

145. Id. at 819 .

146. See id. at 830 .

147. Id. at 825 .

148. See, e.g., H. Scott Gordon, The Economic Theory of a CommonProperty Resource: The Fishery, 62 J. POL. ECON. 124, 124 (1954) (examining an economic theory for commonly owned natural resources). 
bar someone from using their mark. While non-excludability is a feature of all marks, Schechter focused his proto-commons analysis on strong marks because they were presumably the ones that many other firms would want to copy. 149 Seen in this light, dilution was a remedy designed to combat a looming commons tragedy by giving mark owners more power to protect their resource.

Even though Schechter advocated dilution as the best way to protect the new mark, he conceded that the common law might accomplish the same goal by adapting the consumer confusion test. Right after propounding his "whittling" definition of dilution, he stated that "as in so many other phases of legal history the courts may arrive at this result by indirection, i.e., by the distinction which ... is gradually... being drawn between common or semi-descriptive marks or names on the one hand, and arbitrary or fanciful trademarks or tradenames on the other."150 Even in the 1920s, arbitrary and fanciful marks were starting to get broader protection, and Schechter applauded this initial effort to bring infringement into the modern age. ${ }^{151}$

Nonetheless, Schechter's enthusiasm for dilution remained undiminished. As he summarized his position,

[T]he following principles necessarily emerge: (1) that the value of the modern trademark lies in its selling power; (2) that this selling power depends for its psychological hold upon the public, not merely upon the merit of the goods upon which it is used, but equally upon its own uniqueness or singularity; (3) that such uniqueness or singularity is vitiated or impaired by its use upon either related or non-related goods; and (4) that the degree of its protection depends in turn upon the extent to which, through the efforts or ingenuity of its owner[s], it is actually unique and different from other marks. ${ }^{152}$

Seventy years later, these words are still rattling trademark law.

\section{THE SCHECHTER DILUTION FoRMULa CRITICIZED}

While Schechter's recognition of the quality-identifying function of marks has been widely accepted, his rationale for dilution remains controversial. Critics have identified four major problems with his proposal. First, they say there is no pub-

149. See Carter, supra note 33, at 762.

150. Schechter, supra note 1 , at 826 .

151. See id. at 826-28.

152. Id. at 830-31. 
lic purpose served by protecting the persuasive power of marks. Second, dilution may run afoul of constitutional limitations on intellectual property protection. Third, it is far from clear that numerous non-confusing uses of a strong mark diminish its selling power. Fourth, infringement protection for the marks Schechter was worried about has expanded so much since the 1920 s that dilution has become unnecessary.

Schechter was correct when he observed that marks possessed persuasive power, but he never explained what public policy was furthered by protecting persuasiveness. His opaqueness on this important question requires us to make an argument for him. ${ }^{153}$ Ordinarily, American law does not grant property rights merely because a putative owner has invested significant resources in creating something. Unless Schechter's formula is understood as establishing a kind of natural property right for mark owners, ${ }^{154}$ protecting the commercial mag-

153. If marks have a persuasive function, and trademark law is geared towards preventing mark functions from being substantially impaired, then why should persuasiveness go unprotected? The answer is that trademark doctrine already protects the commercial magnetism of marks indirectly. See Klieger, supra note 9, at 861-62. As framed by Schechter, however, dilution argues that persuasiveness should receive additional protection and become the focal point of trademark analysis. We therefore need to determine if there is any reason to follow this prescription. See id. at 862 .

154. A sophisticated argument defending dilution partly on natural rights grounds has been made recently by Kristine Boylan. See Boylan, supra note 20, at 18-21. Boylan contends that Schechter's proposal should be construed as embodying a Lockean labor theory of property. See id. at 18-26. She also suggests that an appropriate analogy for dilution is the common law right of publicity, which gives celebrities control over the use of their personas in advertising. See, e.g., Onassis v. Christian Dior-New York, Inc., 472 N.Y.S.2d 254, 263 (Sup. Ct. 1984); Boylan, supra note 20, at 28. Just as famous personalities have a property right in themselves, Boylan says, dilution can be understood as giving famous corporations a property right in their corporate personas. Boylan, supra note 20 , at 31 .

There are two major problems with this analysis. First, a natural rights theory of dilution is inconsistent with the utilitarian justifications that support property rights elsewhere in the law. Second, the analogy between dilution and the right of publicity does not work well. A right of publicity is usually justified on two grounds. First, Prosser argued that the common-law right of privacy gives celebrities an inherent right to profit from their own likeness. See William L. Prosser, Privacy, 48 CAL. L. REV. 383, 389 (1960). This obviously does not carry over well into the corporate context. Second, some have argued that famous celebrities need protection because their personalities are valuable social resources that face commons depletion. See generally Mark F. Grady, A Positive Economic Theory of the Right of Publicity, 1 UCLA ENT. L. REV. 97 (1994) (arguing that the right of publicity is needed in order to ensure that publicity assets are not wasted through exploitation). As we saw earlier, Schechter's original proposal was based on a similar commons rationale. See 
netism of marks can be justified only if that generates some sort of social benefit. 155

Figuring out whether Schechter's argument for dilution fosters social value necessitates some discussion of how trademark law differs from its intellectual property cousins of copyright and patent. Those two legal regimes give exclusive control to authors and inventors for many years, and then their creations enter the public domain. ${ }^{156}$ This enables the public to utilize intellectual property while giving creators an incentive to innovate. Trademark infringement law, on the other hand,

supra text accompanying notes 148-50. The subsequent discussion demonstrates, however, that no social benefit comes from safeguarding the persuasiveness of marks beyond the protection already provided by infringement doctrine.

Boylan's approach boils down to an argument that dilution constitutes "unjust enrichment" and therefore must be stopped. See Boylan, supra note 20 , at 28. But this does not get us very far. Under Boylan's theory, dilution is unjust mainly because the mark owner has a Lockean property right. Without this natural rights premise-for which there is no support-Boylan's position basically collapses.

155. Some other theories offered by dilution supporters can be quickly dismissed. Bannon argues that without dilution junior users would obtain an unjustified "naked license." Bannon, supra note 10, at 109. This refers to the traditional view that marks cannot be licensed to other firms unless there is some assurance that the licensee will produce goods similar in quality to the mark owner. Id. at 79-80. Unfortunately, Bannon does not explain why ordinary infringement doctrine fails to address the "naked license" problem. Junior uses falling outside the reach of consumer confusion are so tenuously connected to the associations created by a mark that they cannot really be characterized as licenses at all.

Another rationale for dilution is that it prevents "genericide." This doctrine describes the revocation of trademark rights once a mark becomes the commonly used term for a type of good rather than just a brand name. See Welkowitz, supra note 10, at 558-59; see, e.g., Kellogg Co. v. Nat'l Biscuit Co., 305 U.S. 111, 116 (1938) (finding "Shredded Wheat" to be generic); Bayer Co. v. United Drug Co., 272 F. 505, 510-11 (S.D.N.Y. 1921) (finding “Aspirin" generic). By preventing the common use of a strong mark, dilution halts genericide in its tracks.

There is, however, no particular reason to think that genericide ought to be prevented. If the phenomenon occurred frequently, then an argument could be made that the resulting disruption to trademark rights requires a remedy. Genericide, however, is a rare event. The doctrine revokes the rights of very few mark owners, but in so doing avoids giving protection to marks that have become synonymous with the product itself. See Nabisco, Inc. v. PF Brands, Inc., 191 F.3d 208, 215 (2d Cir. 1999) (discussing generic marks). This strikes a sensible balance between public and private rights, and hence using dilution to protect those few senior users who may lose their investments due to genericide would be inappropriate.

156. See, e.g., Klieger, supra note 9, at 864-65 (comparing inventors rights in patent, copyright, and trademark law). 
has traditionally struck a different balance. While mark owners do not get exclusive control over their "property," their rights last as long as the mark continues to designate a particular source in commerce. 157

Although infringement theory acknowledges that senior users need some incentive to mark their goods, once that threshold is crossed there are no additional benefits reaped by giving stronger incentives for mark owners to create new or better marks. As Stephen L. Carter explains,

[T]rademark law may be described as indifferent to the creation of marks, in the sense that the number of marks makes no difference. One might conceive of an optimal supply of copyrighted works or patented inventions, but it makes no sense to refer to an optimal supply of marks as such. All that is needed is a different mark for each producer. ${ }^{158}$

An increased number of copyrights and patents may generate social value, but more (or more clever) trademarks do no such thing. Simply put, this is because marks do not actually affect the quality of goods and services. ${ }^{159}$ In the end, protecting persuasiveness only encourages companies to invest more

157. See, e.g., Landes \& Posner, supra note 45, at 287 (stating that trademarks are tied to distinct physical property).

158. Id.

159. Product designs may constitute an exception. See Ralph S. Brown, Design Protection: An Overview, 34 UCLA L. Rev. 1341, 1403 (1987) (arguing for short-term design protection). After all, a pleasing product design might well add value to certain products. In a few trade dress cases, courts have employed the language of dilution to expand protection for product designs. See, e.g., Esercizio v. Roberts, 944 F.2d 1235, 1245 (6th Cir. 1991); see also id. at 1250-51 (Kennedy, J., dissenting). Some commentators have argued that this is appropriate because design patents do not provide enough incentives for designers. See Daniel J. Gifford, The Interplay of Product Definition, Design and Trade Dress, 75 MINN. L. REv. 769, 779-92 (1991). Others contend that the indirect protection of designs through trademark law is wrong and that the answer lies in a new design patent statute. See Gleiberman, supra note 55 , at $2070-71$.

This debate repeats a theme that runs throughout this Article: namely, that dilution is best conceived as an obsolescence remedy. To the extent that dilution fixes obsolete design patent law, that role might be appropriate in an abstract sense. The practical interaction of dilution with design patents, however, basically renders the question moot. Product designs (as opposed to ordinary marks or labels) only run in a particular line of goods (i.e., the Cadillac tail fin does not get put on sofas). Trade dress claims involving designs are therefore likely to occur only between direct competitors, where infringement protection is at its zenith. Accordingly, dilution will almost never extend more protection to strong product designs than infringement already provides. See infra text accompanying notes 165-67. 
in marks without leading to any clear public benefit. 160 Thus, the argument for giving persuasiveness special protection fails.

Next, there are constitutional pitfalls presented by Schechter's dilution formula. Pursuant to Article One, Section Eight, Congress can grant protection to patents and copyrights only "for limited Times."161 As was noted earlier, trademark rights have an unlimited duration as long as the mark identifies a particular source. Therefore, if Schechter's remedy creates property rights for marks that approximate copyrights and patents, there are serious questions as to whether dilution can survive constitutional scrutiny. Both the First and Fourth Circuits have alluded to this concern while narrowly construing the FTDA. ${ }^{162}$ Interpretive techniques can massage this issue, but the constitutional problems raised by Schechter's rationale just point out another weakness in his approach.

Even if there was a good reason to protect the commercial magnetism of marks that could pass constitutional muster, there is no evidence that a blizzard of non-confusing uses actually dilutes a mark's advertising power. ${ }^{163}$ Essentially, Schechter's proposal "suffers from a critical defect of a priori reasoning. He assumes that marks in fact are diluted and that this dilution can occur in the absence of confusion."164 It is difficult to imagine, as Schechter assumed, that consumers will respond less readily to a strong mark like Kodak if some non-confusing, and hence marginal, junior uses exist in the marketplace. One could just as easily argue that those junior references are like literary allusions, which tend to reinforce rather than diminish

160. Moreover, protecting mark persuasiveness may have significant anticompetitive effects by erecting barriers to entry in a variety of markets. For a detailed discussion, see Klieger, supra note 9, at 862-63.

161. U.S. CONST. art. I., $\S 8$, cl. 8 (stating that Congress has the power " $[\mathrm{t}] \mathrm{o}$ promote the Progress of Science and useful Arts, by securing for limited Times to Authors and Inventors the exclusive Right to their respective Writings and Discoveries").

162. See Ringling Bros.-Barnum \& Bailey Combined Shows, Inc. v. Utah Div. of Travel Dev., 170 F.3d 449, 456 (4th Cir. 1999), cert. denied, 528 U.S. 923 (1999); I.P. Lund Trading ApS, Inc. v. Kohler Co., 163 F.3d 27, 50-51 (1st Cir. 1998); id. at 51 (Boudin, J., concurring).

163. This line of attack is somewhat unfair. When Schechter was writing, the range of non-confusing uses was much greater than it is today precisely because of the infringement obsolescence that he was trying to correct. As a result, it was much easier for Schechter to assume that non-confusing uses would dilute marks. Nevertheless, evaluating his dilution proposal requires us to look at the law in the here and now.

164. Welkowitz, supra note 10, at 538 (emphasis added). 
than diminish the power of the original source. Schechter never provided any evidence to support his view of the corrosive impact of non-confusing uses, and none of his acolytes have either. ${ }^{165}$ Moreover, Schechter may well have focused on the wrong kinds of marks. If anything, weak marks struggling to establish their commercial identities would seem more vulnerable to being overwhelmed by multiple junior uses than strong marks. ${ }^{166}$ As a matter of fact, some dilution supporters have argued that weak marks should be covered by the remedy notwithstanding Schechter's position. ${ }^{167}$

Finally, even if there were sound policy and constitutional justifications for dilution, the doctrine's critics contend that infringement protection for famous marks is now so broad that dilution has been rendered superfluous. ${ }^{168}$ Schechter's intuition that the common law might someday expand consumer confusion to deal with his concerns has come to pass. As one commentator describes the current state of the law, the judiciary's "increased willingness to find an actionable likelihood of confusion has meant that, as a practical matter, nearly any unauthorized use of a [strong] trade symbol with the potential to undermine the symbol's trademark distinctiveness may persuade a federal judge to grant an injunction."169 Accordingly, today there is virtually no junior use of a strong mark like Coca-Cola, Honda, or Kodak that would be deemed nonconfusing in an infringement suit. 170 In this sense, Schechter's version of dilution can be viewed as a remedy without a wrong, since his proposal has been shoved aside by a bigger and better confusion test.

\section{THE MYSTERIES OF DILUTION LAW}

The holes in Schechter's reasoning obviously undermine his proposal, but the problems do not stop there. To a remarkable extent, Schechter's proposal looks nothing like the doctrine that calls him father. This suggests that courts have grafted a somewhat different conception of dilution onto the original

165. The best analysis on this point is by Welkowitz. See id. at 539-44.

166. See id. at 540 .

167. See, e.g., 3A RUdOLPH CALLMANN, THE LAW OF UNFAIR COMPETITION, TRADEMARKS AND MONOPOLIES $§ 21.12$ (4th ed. 1983).

168. See Litman, supra note 11, at 1722; Schechter, supra note 1, at 826.

169. Litman, supra note 11 , at 1722.

170. See, e.g., Klieger, supra note 9, at 861-62; Litman, supra note 11, at 1724 n.44. 
idea, and that Schechter's construction should be abandoned. So let us examine two significant gaps between his theory and modern dilution: (1) tarnishment and (2) the confusion in dilution doctrine.

\section{Tarnishment}

The most striking way in which Schechter and modern dilution part company is through tarnishment, which involves a junior use that has an unwholesome or shoddy reputation in comparison to the senior mark. While tarnishment now comprises one of the two flavors of dilution, Schechter said nothing about it. Furthermore, tarnishment seems to be at odds with the entire concept of dilution. After all, tarnishment involves a direct and obvious injury to a mark that is likely to occur only once. This is exactly the opposite of the subtle but corrosive multiple junior uses that Schechter was worried about. ${ }^{171}$ Even if tarnishment does square with dilution, it should be unnecessary because it is already basically covered by Schechter's idea. If a junior use of a strong mark is diluting, then surely such a use that also injures the reputation of the senior user would be diluting.

Due to this conflict between tarnishment and Schechter's proposal, many of dilution's supporters and detractors have concluded that tarnishment is not a legitimate part of dilution. ${ }^{172}$ While conceding that tarnishment may be a harm worth addressing via some other legal theory, they maintain that it "is both unduly broad in scope and largely unrelated to the dilution concept."173 Yet tarnishment remains a co-equal partner (with blurring) in dilution law. So as an initial matter, Schechter's reasoning cannot explain about half of dilution doctrine.

171. See Klieger, supra note 9, at 830 ("If the aim of dilution law is to prevent the gradual whittling away of trademark value by enjoining junior uses of a mark that threaten to destroy the selling power of the mark only in the aggregate, then tarnishment should not qualify as dilution at all.").

172. See Bannon, supra note 10, at 111; Klieger, supra note 9, at 830-31; Welkowitz, supra note 10, at 587-88.

173. Beverly W. Pattishall, Dawning Acceptance of the Dilution Rationale for Trademark-Trade Identity Protection, 74 TRADEMARK REP. 289, 306-07 (1984) (footnotes omitted). 


\section{Applying Dilution}

Moreover, seven decades after Schechter's article was published, courts are still unable to figure out what dilution means. ${ }^{174}$ The first comprehensive attempt to analyze blurring claims came in Judge Robert Sweet's concurring opinion in Mead Data Central, Inc. v. Toyota Motor Sales, U.S.A., Inc. ${ }^{175}$ Judge Sweet argued that six factors ought to govern a blurring analysis: (1) the similarity of the marks; (2) the similarity of the products covered by the marks; (3) the sophistication of consumers; (4) predatory intent; (5) the renown of the senior mark; and (6) the renown of the junior mark. ${ }^{176}$ The so-called Sweet factors, however, have come under serious attack from courts and commentators and are no longer a reliable guide for evaluating blurring claims. ${ }^{177}$

All the circuits can agree on, however, is that they do not like Judge Sweet's framework. As a result, the standards of blurring law vary widely. The First Circuit has argued that only three of the Sweet factors (mark similarity, product similarity, and senior mark renown) are relevant under the FTDA. ${ }^{178}$ For the Seventh Circuit, only two Sweet factors (mark similarity and senior mark renown) are useful. 179 The Second and Third Circuits contend instead that the likelihood of confusion factors should be applied under the FTDA's dilution prong to ascertain whether blurring has occurred. ${ }^{180}$ Not to be outdone, the Ninth Circuit has explained that the confusion factors should essentially be used under the FTDA's fame prong rather than the dilution prong. ${ }^{181}$

174. See, e.g., Ringling Bros.-Barnum \& Bailey Combined Shows, Inc. v. Utah Div. of Travel Dev., 170 F.3d 449, 455-56 (4th Cir. 1999), cert. denied, 528 U.S. 923 (1999).

175. 875 F.2d 1026, 1035 (2d Cir. 1989) (Sweet, J., concurring). Tarnishment law is not a model of clarity either, but this discussion will look at how courts have handled blurring actions since they reflect Schechter's original model.

176. See id. at 1035.

177. See Ringling Bros., 170 F.3d at 464; I.P. Lund Trading ApS, Inc. v. Kohler Co., 163 F.3d 27, 49-50 (1st Cir. 1998); Welkowitz, supra note 10, at 572-73.

178. See I.P. Lund, 163 F.3d at 49-50.

179. See Eli Lilly \& Co. v. Natural Answers, Inc., 233 F.3d 456, 468-69 (7th Cir. 2000).

180. See Times Mirror Magazines, Inc. v. Las Vegas Sports News, L.L.C., 212 F.3d 157, 168 (3d Cir. 2000), cert. denied, 69 U.S.L.W. 3259 (Jan 8, 2001); Nabisco, Inc. v. PF Brands, Inc., 191 F.3d 208, 217-22 (2d Cir. 1999).

181. See Avery Dennison Corp. v. Sumpton, 189 F.3d 868, 879 (9th Cir. 
In contrast, the Fourth and Fifth Circuits have opined that plaintiffs must establish "actual dilution" of their mark and therefore contextual factors like those proposed by Judge Sweet are almost always inappropriate. These circuits contend that only direct evidence of lost sales or sophisticated consumer surveys can establish actual dilution. 182 The actual dilution standard of proof articulated by these courts is based on the FTDA's statement that a plaintiff must show that the offending use "causes dilution." This is in contrast to most state dilution laws, which require only a showing of "likelihood of dilution." 183 Thus, the Fourth and Fifth Circuits have concluded that the federal statute must incorporate a more stringent standard of proof. As a matter of textual construction, they may be correct. But the problem with their interpretation, as the Second and Seventh Circuits have observed, is that the actual dilution standard "holds plaintiffs to an impossible standard of proof."184

Each of these approaches to the FTDA has its problems, but the important point is that the same legal concept has generated so many different tests. ${ }^{185}$ When so many courts acting in good faith cannot make sense out a legal formula, whether embodied in a statute or an article, that suggests the presence of a defect in the authority the courts have been given. ${ }^{186}$

As this discussion demonstrates, Schechter made his proposal in response to valid concerns about the state of trademark law during the early twentieth century. Unfortunately,

1999). There is probably no meaningful difference between the Second, Third, and Ninth Circuit approaches, but the Ninth Circuit's framework of analysis in dilution cases is still a little unclear.

182. See Westchester Media L.L.C. v. PRL USA Holdings, Inc., 214 F.3d 658, 670-71 (5th Cir. 2000); Ringling Bros., 170 F.3d at 463-65.

183. See Westchester, 214 F.3d at 670-71.

184. Eli Lilly, 233 F.3d 456, 468-69 (7th Cir. 2000); see Nabisco, 191 F.3d at 224.

185. The Fourth and Fifth Circuit's faith in consumer surveys seems misplaced. As Nabisco noted, consumer surveys are quite subject to manipulation and are therefore not highly reliable. See Nabisco, $191 \mathrm{~F} .3 \mathrm{~d}$ at 224 . But see Bible, supra note 9 (advocating the use of consumer surveys to prove dilution under the FTDA).

As for the Second, Third, and Ninth Circuit frameworks, there is nothing wrong with applying the confusion factors in a blurring case since dilution follows from confusion. The problem is that dilution claims often do not involve consumer confusion, and then the confusion factors will not be helpful. For a closer examination of why the confusion factors may not speak to dilution, see Klieger, supra note 9, at 826-27; Welkowitz, supra note 10, at 573-74.

186. For more on how the FTDA ought to be interpreted, see infra Part V.D.3. 
his explanation of dilution does not work. It has faltered under academic scrutiny; it may be unconstitutional; it does not explain tarnishment doctrine; and it cannot be applied clearly. The time has come to seek out a new interpretation of dilution that addresses these issues.

\section{LEGAL OBSOLESCENCE AND OVERSHOOTING}

This Part reads Schechter's dilution proposal as a remedy against infringement obsolescence. After examining this alternative interpretation in the context of the broader legal obsolescence problem, the analysis assesses the transformation of the relationship between dilution and infringement once dilution is given an obsolescence gloss. One part of that transformation is the risk of "overshooting" that inheres in dilution or any other effort to revise outdated laws. Broad statutes designed to help courts keep the law abreast of economic and social change can often lead to excessive protection of the legal interest at stake. In other words, by trying hard to avoid falling behind, the law may end up racing too far ahead. ${ }^{187}$

\section{A. MISCHIEVOUS INTERPRETATION}

Just as ambiguous or unworkable statutes are often interpreted by focusing on the mischief the law is directed against, Schechter's article can be construed by looking at the mischief he was worried about: obsolete infringement law. ${ }^{188}$ Defects in the consumer confusion test were an important focus of Schechter's 1925 treatise. ${ }^{189}$ A few years later, his dilution article made repeated references to an outdated common law understanding of marks that needed fixing. ${ }^{190}$ Moreover, commentators in subsequent decades have argued that Schechter was motivated by a desire to modernize trademark law. ${ }^{191}$ All

187. As the Roman Emperor Hadrian (117-138 A.D.) once commented, "Laws change more slowly than custom, and though dangerous when they fall behind the times [they] are more dangerous still when they presume to anticipate customs." MARGUERITE YOURCENAR, MEMOIRS OF HADRIAN 113 (Grace Frick trans. 1954).

188. See, e.g., Heydon's Case, 3 Co. Rep. 7a, 7b, 76 Eng. Rep. $637-38$ (1584) (noting that "the office of all the Judges is always to make such construction as shall suppress the mischief, and advance the remedy").

189. See Ringling Bros.-Barnum \& Bailey, Inc. v. Utah Div. of Travel Dev., 170 F.3d, 449, 454 (4th Cir. 1999), cert. denied, 528 U.S. 923 (1999); SCHECHTER, supra note 30 , at 164-66.

190. See Schechter, supra note 1 , at $813-14,818,824,826$.

191. See Boylan, supra note 20, at 25; Klieger, supra note 9, at 810; Lit- 
in all, there is little doubt that musty infringement doctrine was the mischief that sparked the original dilution proposal.

This view of Schechter's remedy is reinforced by the fact that he wrote during a time when scholars commonly decried the common law's inability to keep up with the needs of a modern industrial economy. ${ }^{192}$ In part, the hidebound state of the common law at that time "may have been due to the dominance in the late nineteenth and early twentieth centuries of legal formalism, which ... reduced the willingness and capacity of courts to perform their traditional role as reshapers of the common law."193 Whatever the explanation, legal thinking during the first half of the twentieth century tended to exalt broad statutes guided by administrative agencies as the best method of commercial regulation. ${ }^{194}$ Faith in statutory reform and administrative agencies has been tempered by experience, but that era's view of the relative merits of statutes and the common law must be taken into account when interpreting Schechter's proposal.

Give the statutory mischief dilution was directed toward and the problems that follow from Schechter's reasoning, it is perfectly reasonable to construe dilution as a more narrow remedy for infringement obsolescence. This does not mean that an obsolescence reading of Schechter's remedy is the best construction of what he actually meant. Even a cursory review of his argument shows that he did want to protect the persuasive power of distinctive marks by barring most unauthorized commercial uses of those marks. If we were interpreting a statute, the legitimacy of a reading that ignored such clear authorial intent would be shaky unless serious constitutional concerns ne-

man, supra note 11, at $1724 \mathrm{n} .41$.

192. See GUIDO CAIAABRESI, A COMMON LAW FOR THE AGE OF STATUTES 75 (1982). See generally James McCauley, Landis, Statutes and the Sources of Law, in HARV. LEgal Essays 213 (1934); Roscoe Pound, Common Law and Legislation, 21 HARV. L. REV. 383 (1908); Harlan F. Stone, The Common Law in the United States, 50 HARV. L. REV. 4 (1936).

193. CALABRESI, supra note 192, at 75; see GRANT GILMORE, THE AGES OF AMERICAN LAW 60-61 (1977).

194. For more on the obsolescence problem and a statutory solution, see CALABRESI, supra note 192, at 44-58; infra text accompanying notes 201-06. Schechter was sympathetic to the idea of getting administrative agencies heavily involved in trademark protection. In his treatise, he suggested that the regulation of marks could be removed from the common law entirely and placed under the auspices of the Federal Trade Commission. See SCHECHTER, supra note 30, at 164-65; Klieger, supra note 9, at 807 . 
cessitated the construction. ${ }^{195}$ Since Schechter's proposal was in the form of an article, however, we have more interpretive flexibility. Accordingly, a recharacterization of dilution into a limited tool of infringement reform is both desirable and possible.

Of course, just because an obsolescence reading of dilution is plausible does not mean that it is any better than Schechter's version. 196 Only by comparing a revisionist interpretation with the actual development of trademark law over the decades can its merits be evaluated. Before beginning that examination, however, the implications of injecting dilution into the legal obsolescence debate must be considered.

\section{B. MUSTY STATUTES AND DYNAMIC INTERPRETATION}

Over the past thirty years, legal obsolescence has become a significant concern for academic commentators. ${ }^{197}$ In express-

195. It could be argued that legislatures passed dilution laws pursuant to Schechter's reasoning, and therefore statutes are being interpreted (or reinterpreted) by providing a new reading to Schechter's article. Although his argument certainly formed the backdrop of state dilution laws and the FTDA, little in the text or legislative history of these statutes refers directly to Schechter or to his ideas. Moreover, legislatures have not simply enacted Schecter's proposal jot-for-jot, hence we should not give his rationale the authority of a statutory enactment. See Ringling Bros.-Barnum \& Bailey Combined Shows, Inc. v. Utah Div. of Travel Dev., 170 F.3d 449, 456 (4th Cir.), cert. denied, 528 U.S. 923 (1999).

196. Once dilution is cast as an obsolescence remedy, however, many conceptual objections to dilution disappear. First, dilution no longer seeks to protect the persuasive power of marks, so that ground of criticism becomes moot. Second, there are no constitutional problems with using dilution primarily as a means of extending protection in the face of outdated consumer confusion test-assuming that such obsolescence actually exists.

One could still argue that dilution is unnecessary because infringement law is currently providing adequate protection, but this attack is unavailing. For one thing, proponents of a limited version of dilution can concede that it is not needed now but maintain that it should be kept on the books in case infringement ever stumbles. More important, as Part VI shows, dilution has recently proven useful in safeguarding the location-identifying function of marks on the Internet. See infra Part VI.B.

197. See, e.g., CALABRESI, supra note 192; WLLIAM N. ESKRIDGE JR. \& PHILLIP P. FRICKEY, LEGISLATION: STATUTES AND THE CREATION OF PUBLIC PolICY (1988); Jack Davies, A Response to Statutory Obsolescence: The Nonprimacy of Statutes Act, 4 VT. L. REV. 203 (1979); Henry J. Friendly, The Gap in Law Making-Judges Who Can't and Legislators Who Won't, 63 Colum. L. REv. 787 (1963); Donald C. Langevoort, Statutory Obsolescence and the Judicial Process: The Revisionist Role of Courts in Federal Banking Regulation, 85 MICH. L. REV. 672 (1987).

In the intellectual property context, Bruce $\mathrm{P}$. Keller has pointed out that a 
ing this concern, obsolescence scholars have focused primarily on outdated statutes. This reflects both the prevalence of statutory law in the American system and some disenchantment with the legal process consequences of the modern welfare state. ${ }^{198}$ What particularly interests these authors is the cumbersome way in which statutes are enacted. As we all learn in civics class, bills must go through many hoops before becoming law. ${ }^{199}$ While this legislative inertia serves a valuable role by protecting the rights of minorities in our society, the downside is that, once passed, statutes can be difficult to change. ${ }^{200}$ The potential for statutory obsolescence is compounded by the fact that, due to the principle of legislative supremacy, courts are ordinarily not permitted to "sunset" old statutes in the way that they often retire outdated common-law holdings. ${ }^{201}$

Several creative approaches have been proposed to deal with statutory obsolescence when legislatures fail to resolve the problem themselves. The school of "dynamic statutory interpretation" argues that courts should update statutes by giving them broad and purposive readings when "societal and legal circumstances have changed so as to unravel material assump-

variety of archaic common law doctrines help fix obsolescence in copyright and trademark law. See Keller, supra note 34, at 403. For instance, he argues that the Supreme Court's creation of the oft-criticized tort of misappropriation in International News Service v. Associated Press, 248 U.S. 215 (1918), was largely the result of technology outpacing the development of federal copyright statutes. See Keller, supra note 34, at 406-07; see also Brown, supra note 16, at 1200 (criticizing misappropriation as based on a "gross fallacy"). Just as an aside, Keller notes that some of the early misappropriation cases would probably have fallen within the scope of dilution had it existed at the time. See Keller, supra note 34, at 412 n.52; see also Brown, supra note 16, at 1200 (comparing dilution and misappropriation).

198. As Grant Gilmore once quipped, we have witnessed an "orgy of statute making." See GILMORE, supra note 193, at 95. Some fifty percent of the Supreme Court's opinions each term concern statutory interpretation. See WILLIAM N. ESKRIDGE JR., DYNAMIC STATUTORY INTERPRETATION 335 n.3 (1994).

199. Some of the obstacles to legislative action include (1) legislative committees, (2) bicameralism, (3) filibusters, and (4) the executive veto.

200. Eskridge and Frickey identify four categories of statutory obsolescence: (1) quantity (specific figures that fall out of date), (2) policy (the fit between an old statute and more current law), (3) priority (the attention given to a particular issue as against others), and (4) remedy. ESKRIDGE \& FRICKEY, supra note 197, at 844-45.

201. See, e.g., Daniel A. Farber, Statutory Interpretation and Legislative Supremacy, 78 GEO. L.J. 281, 283 (1989). 
tions made in the statute."202 Another author contends that courts have used literalism as a technique to bring obsolete banking statutes into line with modern policy norms. ${ }^{203}$ A third view is that judges should be given a common law power over statutes precisely so that obsolete laws (like outdated common law rules) can be gradually phased out.204 Finally, there is the idea that administrative agencies should be delegated broad authority to adjust statutes when necessary. ${ }^{205}$ All four approaches have their critics, of course, but together these doctrines point out that statutory obsolescence is a troubling issue that raises profound legal process questions. ${ }^{206}$ Viewing dilution statutes as an obsolescence remedy adds a new dimension to this debate.

\section{Dilution AND "REVERSE-OBSOLESCENCE"}

A revisionist interpretation of dilution breaks with the consensus of legal obsolescence scholarship in two major respects. First, Schechter was concerned about common-law obsolescence, not statutory obsolescence. Indeed, in line with the prevailing legal process values of his time, he viewed statutes as the solution to outdated legal rules. ${ }^{207}$ Modern proponents of obsolescence remedies do not contend that the common law is immune from aging, but they virtually all agree that the common law is far better than the legislative process at handling changing circumstances. ${ }^{208}$ Second, in the dilution context, the

202. ESKRIDGE, supra note 198, at 112.

203. See Langevoort, supra note 197, at 729-30. Langevoort's argument is that advances in financial practices over the decades made the intent behind Depression-era banking statutes like the Glass-Steagall Act increasingly obsolete. See $i d$. To limit the potential damage of these laws, courts construed them literally and thereby blunted their impact. See id. at 716-19, 729-30.

204. See CALABRESI, supra note 192, at 91-167.

205. See id. at 44-59.

206. For thoughtful essays questioning the entire project of resolving obsolescence through judicial action, see Robert Weisberg, The Calabresian Judicial Artist: Statutes and the New Legal Process, 35 STAN. L. REV. 213 (1983); John Copeland Nagle, Newt Gingrich, Dynamic Statutory Interpreter, 143 U. PA. L. REV. 2209 (1995) (reviewing WILLIAM N. ESKRIDGE JR., DYNAMIC STATUTORY INTERPRETATION (1994)).

207. See supra text accompanying notes 192-94 (describing the prevailing thought on common-law obsolescence).

208. See CALABRESI, supra note 192, at 73 ("Obsolete laws do not really exist, the devotees of the common law would say, when legal rules respond in a changing, accretional, and continuous way to the underlying principles of the people.").

This is a debate that need not be resolved here. It is worth pointing out, 
obsolescence remedy was enacted as a statute that looked like substantive law. Edward L. Rubin has pointed out that many statutes are better understood as establishing directives to other organs of government "rather than as a set of rules for the governance of human conduct."209 That is the case here. Although dilution is in the form of and was partly intended to be a substantive rule (i.e., Schechter's approach), we will see that it behaves like a directive to the courts to root out trademark protection obsolescence. ${ }^{210}$

Dilution's unique role as an enacted obsolescence remedy raises three important questions. First, what should such an anti-obsolescence statute look like? Second, what happens during those periods when a statute designed to fight obsolescence itself becomes obsolete?211 Third, is there a danger in putting an obsolescence remedy into a substantive form? The first issue is the easiest. To give courts the maximum flexibility in dealing with doctrinal obsolescence, dilution statutes would need to be drafted as broadly as possible. ${ }^{212}$ This, of course, is basically what happened. Of course, interpreting these expansive laws poses the considerable challenge that this Article seeks to address.

Resolving the second issue throws light on the deep connections between infringement and dilution. Under an obsolescence reading of Schechter, if infringement was not doing its job at any particular time, we would expect dilution to receive a liberal reading and thereby accomplish its objective. But sup-

however, that legislative inertia prevented Schechter's proposal from being enacted for more than twenty years. See infra text accompanying notes 24648. Furthermore, by the time dilution laws were finally passed, the common law had made considerable progress in easing infringement's obsolescence. See infra text accompanying notes 246-48. As a result, Schechter's confidence in the legal-process superiority of legislatures may have been misplaced.

209. Edward L. Rubin, Law and Legislation in the Administrative State, 89 COLUM. L. REV. 369, 371-72 (1989).

210. Of course, applying dilution as a substantive rule of law creates all kinds of problems. See supra Parts II.C-D.

211. The Latin maxim "Quis custodiet custodiens?" (Who guards the guards?) captures the second issue.

212. The best way to understand how dilution works is to think of a dog race. To get the dogs to run faster, the track releases a mechanical rabbit from the starting gate so that they will have something to chase. The rabbit goes much faster than any dog could possibly run, but this is precisely what makes it a good lure. Dilution, like the dog-track rabbit, sets a bar of trademark protection that is much higher than society would actually want. Yet this is what allows dilution to exert a gravitational pull that can lift infringement out of its obsolescence when necessary. 
pose that the circumstances were reversed and infringement was doing its job properly. At that point, dilution law would be unnecessary. Accordingly, if dilution acts as an obsolescence remedy, then it follows that it should not be applied when infringement is free from obsolescence.

Stated more generally, if dilution is primarily used as a tool to correct defects in infringement, then dilution and infringement doctrine should move inversely to one another. ${ }^{213}$ This is the pattern that we will be looking for in the case law. ${ }^{214}$ Dilution should achieve its greatest prominence when infringement has obsolescence problems, but then vanish into oblivion when infringement once again meets the needs of trademark protection. Moreover, this harmonious ebb and flow between the two trademark doctrines could go through many repetitions. Each time infringement undergoes a bout of obsolescence the cycle will begin anew. This model means that courts may need to interpret dilution as someone plays an accordion: first broad, then narrow, then broad, and then narrow again. Managing this task without the aid of administrative agencies requires some creative judging.

While using a statute as an obsolescence remedy may create an elegant set of doctrinal relationships, the risk posed by this solution is statutory "overshooting" or "reverseobsolescence." As was mentioned earlier, in order to sweep away outdated rules, dilution statutes have to be drafted broadly. Although courts should not apply these laws when no obsolescence is present, some courts will inevitably err and extend dilution protection in this situation. This could happen because a court fails to see that dilution should not be treated as a substantive rule, or because, in its zeal to carry out dilution's mandate, a court sees obsolescence where there is none. In both cases, the result is the same. Instead of pushing obsolete trademark protection to its proper equilibrium level and then stopping, dilution just keeps on pushing and thereby overshoots the equilibrium point. This ends up giving too much

213. If dilution was primarily a substantive rule, on the other hand, then dilution should basically display a linear relationship that is unconnected to infringement. One could argue that dilution might initially be interpreted narrowly as befits a new remedy, and then gradually expand as it gained acceptance. This pattern is markedly different from the cyclical pattern that would be produced by an obsolescence reading.

214. See infra Parts IV-V. 
protection to mark owners at the expense of the public interest. 215

Overshooting is the mirror opposite of obsolescence. ${ }^{216}$ If legal backwardness is left untended, courts get saddled with a set of rules that do not balance competing societal interests particularly well. Because a statutory solution to obsolescence (as administered by the courts) needs to be drafted broadly, however, its literal application would just end up creating a different set of ill-fitting rules. The only distinction is that each set of ill-fitting rules provides a windfall to different interest group coalitions. Since this would probably not be an improvement over the status quo, dilution and all other obsolescence remedies must guard against overshooting. ${ }^{217}$

Schechter's proposal can reasonably be read as an obsolescence remedy. Furthermore, this reading illuminates new facets of the legal obsolescence debate while offering clear predictions about how dilution and infringement should behave. Now it is time to see how dilution and infringement have actually interacted.

215. See White v. Samsung Elecs. Am., Inc., 989 F.2d 1512, 1513 (9th Cir. 1993) (Kozinski, J., dissenting from the denial of rehearing en banc) ("Overprotecting intellectual property is as harmful as underprotecting it. Creativity is impossible without a rich public domain. .. . Culture, like science and technology, grows by accretion, each new creator building on the works of those who came before. Overprotection stifles the very creative forces it's supposed to nurture.").

216. In the context of the judicial or interpretive solutions to statutory obsolescence canvassed earlier, the overshooting phenomenon tends to get wrapped up in a discussion about legitimacy. Rather than focusing on whether courts charged with eradicating obsolescence will go too far and anticipate legal developments, opponents of judicial obsolescence remedies usually challenge the constitutional and democratic validity of judicial value judgments that would override prior legislative decisions.

217. Although there are many circumstances in which courts construe statutes narrowly for policy reasons, that decision is ordinarily premised on the notion that the statute was drafted poorly and therefore needs to be constrained. In the case of dilution, however, there is no error in the statutory language. We want dilution laws to be broad, but we also want them interpreted narrowly on certain occasions.

Perhaps the closest analogy is the criminal law. Penal statutes are ordinarily written in sweeping terms in order to give prosecutors the authority they need to obtain guilty pleas and flip witnesses for information about other crimes. Applying these kinds of laws literally, however, would probably overdeter marginal activity. To prevent this result, the criminal justice system has developed many methods, including prosecutorial discretion, jury discretion, extensive procedural protections, and the rule of lenity to control the application of broad criminal statutes. In the dilution context, however, the burden of preventing overshooting rests entirely on interpreting courts. 


\section{INFRINGEMENT AND DILUTION IN TRANSITION}

This Part offers support for an obsolescence reading of Schechter by looking at the rhythm of trademark doctrine from the publication of his article in 1927 until the development of the modern consumer confusion test in Polaroid.218 As long as infringement remained stuck in a rut, dilution was cited favorably by courts and commentators seeking to preserve the mark's quality function. When judges finally started adapting infringement in the 1940 s and 1950 s, they contextualized the problem of quality-function protection, in part, by finding confusion in cases where a mark's junior user sold shoddy or unsavory goods that could harm the senior user's reputation. This focus on the quality of the junior user's goods would have significant implications for both infringement and dilution. As infringement finally emerged from its obsolescence by the late 1950s and early 1960s, dilution was read into oblivion in accord with the predictions of the conceptual framework.

\section{A. DILUTION IN THE VANGUARD}

Schechter's concept initially received a rousing reception from those who wanted to expand trademark protection in noncompeting goods cases. ${ }^{219}$ A typical example of the early judicial response was Tiffany \& Co. v. Tiffany Productions, Inc. ${ }^{220}$ in which the Tiffany boutique sought to enjoin the use of its

218. Polaroid Corp. v. Polarad Elecs. Corp., 287 F.2d 492 (2d Cir. 1961).

219. See, e.g., Stork Restaurant, Inc. v. Sahati, 166 F.2d 348 (9th Cir. 1948); Philadelphia Storage Battery Co. v. Mindlin, 296 N.Y.S. 176, 179 (N.Y. Sup. Ct. 1937); Tiffany \& Co. v. Tiffany Prods., Inc., 264 N.Y.S. 459, 462 (N.Y. Sup. Ct. 1932), aff'd, 260 N.Y.S. 821 (N.Y.A.D. 1 Dept. 1932), affd, 188 N.E. 30 (N.Y. 1933); Callmann, supra note 20; Klieger, supra note 9, at 814; Beverly Pattishall, The Case for Anti-Dilution Trade-mark Statutes, 43 TRADE-MARK REP. 887 (1953).

Brown contended that in these early years dilution "made little headway." See Brown, supra note 16, at 1195 \& n.124. He correctly observed that dilution was not cited in a large number of cases and that there was an element of confusion in each case where dilution was mentioned. Nevertheless, Schechter's idea was almost always cited favorably when it was discussed, and its use was relatively frequent when one considers that it had not been enacted anywhere during that time. See infra text accompanying notes 246-48. As for the existence of confusion in these early cases, that coheres quite well with an argument that courts used dilution as a tool to extend trademark protection in marginal situations. If no evidence of confusion was present, then, under an obsolescence reading of dilution, using dilution to grant mark owners protection would have been inappropriate. After all, even an updated infringement regime would not have granted relief in such a case.

220. 264 N.Y.S. at 462. 
mark by a local movie theater. ${ }^{221}$ Although the court made a formal finding of likely consumer confusion, the opinion relied heavily on dilution theory and found for the plaintiff. ${ }^{222}$ Tiffany \& Co. expressly adopted Schechter's "whittling" definition of the trademark injury, and then argued that the theater had obtained "an unfair advantage for [itselfl from the good will created by plaintiff in the name. The purpose of [the movie theater's] acts was wrongfully and unfairly to appropriate for [its] pecuniary gain the value plaintiff had created in [its] own name and ... unique business and financial reputation."223 This was not the language of traditional infringement.

An identical approach was on display in Bulova Watch Co. v. Stolzberg. 224 Plaintiff produced "Bulova watches," which was a well-known watch brand at that time. ${ }^{225}$ Defendant, a shoemaker, knew of Bulova watches and decided to market a brand of "Bulova Fine Shoes."226 The Court first held that plaintiff's infringement action could not succeed because, under the restrictive precedents, shoes and watches were not sufficiently similar products to sustain a finding of likely consumer confusion. 227

Although that should have been the end of the case, the Court instead invoked dilution theory and ruled for the plaintiff. As the Court stated, "A use by the defendant, even on noncompeting goods, may result in injury to the plaintiffs reputation and dilute the quality of the trade-mark."228 Since Bulova was a "unique family name," the defendant, "by using the trade-mark on low price shoes, stands to injure plaintiffs reputation and dilute the quality of his trade-mark."229

221. See id. at 460 ; Klieger, supra note 9 , at 815 ; Welkowitz, supra note 10 , at 534 .

222. See Tiffany \& Co., 264 N.Y.S. at 462; Klieger, supra note 9, at 815; Welkowitz, supra note 10, at 534; see also Note, supra note 10, at 525 ("As the likelihood of confusion in any particular case becomes attenuated, the operative role of dilution in prompting relief increases, however orthodox the language in which the decision is announced.").

223. Tiffany \& Co., 264 N.Y.S. at 462-63.

224. 69 F. Supp. 543 (D. Mass. 1947).

225. Id. at 544-45.

226. Id. at 545 .

227. See id.

228. Id. at 547.

229. Id. The Court's concern about the low quality of the junior user's product was a leading indicator of the role quality would play in the development of dilution law. See infra Part V.B. 
To explain the early popularity of dilution, one needs to look no further than at the continuing stagnation in infringement law. After the thunderclap of Schechter's article, there were some indications that courts understood the need to reform the consumer confusion test and protect the mark's quality function. In 1928, Learned Hand authored Yale Electric Corp. v. Robertson, 230 which affirmed a finding of likely confusion between Yale locks and Yale flashlights and batteries. ${ }^{231}$ Hand explained that the modern mark required a broader definition of consumer confusion:

[A] merchant may have a sufficient economic interest in the use of his mark outside the field of his own exploitation to justify inter-position by a court. His mark is his authentic seal; by it he vouches for the goods which bear it; it carries his name for good or ill. If another uses it, he borrows the owner's reputation, whose quality no longer lies within his own control. This is an injury, even though the borrower does not tarnish it, or divert sales by its use; for a reputation, like a face, is the symbol of its possessor and creator, and another can use it only as a mask. ${ }^{232}$

Hand's recognition of the need for greater infringement protection was not limited to a single case. Six years later, in L.E. Waterman Co. $v$. Gordon, ${ }^{233}$ he wrote another opinion affirming an infringement violation, this time involving Waterman fountain pens and Waterman razor blades. ${ }^{234}$ Hand argued that while goods like lipstick and steam shovels might be too unrelated to support a finding of likely confusion, fountain pens and razor blades were still close enough to justify relief.235

Hopes for real change in infringement doctrine were soon dashed, however, as Hand himself led an effort to cut back on

230. 26 F.2d 972 (2d Cir. 1928) (L. Hand, J.).

231. See id. at 974. Hand based his decision on the "Aunt Jemima" doctrine, which held that very closely related products could support a finding of likely consumer confusion. See Aunt Jemima Mills Co. v. Rigney \& Co., 247 F. 407, 410 (2d Cir. 1917) (finding likely consumer confusion between Aunt Jemima pancakes and syrup). The Yale opinion, however, gave an expansive reading to Aunt Jemima that would then be limited for a time by the Second Circuit.

This portion of the analysis focuses on Second Circuit cases. During the relevant time period, Learned Hand's court was the unquestioned leader in trademark law.

232. Yale Elec. Corp., 26 F.2d at 974. Even at this early stage, Hand understood that tarnishment could constitute an injury to the qualityrepresenting function of marks. See id.; infra Part V.

233. 72 F.2d 272 (2d Cir. 1934) (L. Hand, J.).

234. Id. at 273.

235. See id. 
the Yale/Waterman line of cases.236 The turnabout came in 1940 during the first appeal in S.C. Johnson \& Son, Inc. $v$. Johnson, 237 which pitted Johnson floor cleaner against Johnson fabric cleaner. ${ }^{238}$ In contrast to the broad protection Hand had previously advocated, this time he was willing to issue only a limited injunction that required the junior user to put the phrase "made by Johnson Products Company, Buffalo, N.Y." on its fabric cleaner. ${ }^{239}$

Although the use of the same mark on products as closely related as floor cleaner and fabric cleaner was a strong candidate for infringement relief, Hand and some of his colleagues were now more concerned about the danger of giving mark owners a commercial monopoly. ${ }^{240}$ Accordingly, Hand wrote that infringement relief for non-competing goods was warranted under only two circumstances: (1) when the senior user was likely to expand into the junior user's market; (2) when the junior use could injure the senior user's reputation. ${ }^{241}$ This transitional confusion test is explained further in the next section. For now, the critical point is that the modified Hand approach, while a clear effort to help modernize trademark law, still significantly restricted the ability of mark owners to get relief. $^{242}$

236. See S.C. Johnson \& Son, Inc. v. Johnson, 116 F.2d 427 (2d Cir. 1940) (L. Hand, C.J.) (Johnson I), on motion to modify injunction, 175 F.2d 176 (2d Cir. 1949) (L. Hand, C.J.) (Johnson II); 4 MCCARTHY, supra note 10, § 24:55.

237. 116 F.2d 427 (2d Cir. 1940) (L. Hand, C.J.).

238. See Johnson I, 116 F.2d at 428-29. In the second appeal of the case, the plaintiff moved to modify the decree due, inter alia, to the intervening passage of the Lanham Act. See Johnson II, 175 F.2d at 177. The plaintiff argued that the Lanham Act enhanced the substantive rights of mark owners. See id. at 178. Hand wrote for the majority and rejected the plaintiffs motion. In keeping with his new, conservative view of trademark protection, Hand declared that the Lanham Act only codified the existing common law of infringement. See id. at 179. Judge Clark condemned this effort to cut the statute down "to a size consistent with the court's conceptions of public policy." See $i d$. at 180 (Clark, J., dissenting).

239. See Johnson I, 116 F.2d at 430.

240. See, e.g., Fed. Tel. \& Radio Corp. v. Fed. Television Corp., 180 F.2d 250, 252 (2d Cir. 1950) (L. Hand, C.J.). It is unclear what led to Hand's change of heart, but there was a significant trend towards anti-monopoly thinking in intellectual property law during the 1930s and 1940s. See, e.g., Standard Brands, Inc. v. Smidler, 151 F.2d 34, 41-42 (2d Cir. 1945) (Frank, J., concurring).

241. See Johnson I, 116 F.2d at 429.

242. The failure to address this part of the trademark story leads Klieger's dilution analysis a little bit astray. In essence, Klieger contends that the consumer confusion test had expanded adequately by the 1940s to render dilution 
The link between the ascent of dilution and the sluggishness of infringement was recognized by contemporary scholars. For instance, Beverly W. Pattishall, one of dilution's leading advocates, conceded that his support for dilution was mainly due to the inadequate protection that the confusion test provided to the modern mark. ${ }^{243}$ Meanwhile, other commentators agreed that infringement needed to be expanded, and they therefore suggested that the baseline for measuring confusion be changed from the "reasonably careful purchaser" to the "ignorant purchaser."244 In sum, most experts at that time agreed on the need to expand trademark protection. The central question was whether this should be accomplished through a much broader confusion test or through dilution. ${ }^{245}$

The enthusiastic response to dilution from the 1920s through the 1940s was all the more remarkable given that dilution was not enacted anywhere until 1947.246 For courts to cite a mere academic theory as a basis for relief during this period was unusual, and demonstrates the desperate desire to fill the void between infringement law and the felt necessities of trademark protection. Of course, one could turn this around and argue that since it took so long to enact dilution in the face of concerns about outdated infringement doctrine, Schechter's proposal cannot properly be read as an obsolescence remedy. This criticism is misplaced. It is perfectly natural to expect that a new approach to trademark protection would initially encounter resistance. Even legislators genuinely concerned with the state of infringement doctrine would have been inclined to give courts more time to adjust the law before impos-

unnecessary. By anticipating the eventual expansion of infringement law, Klieger fails to see that the link between dilution and infringement that he brilliantly identified in Schechter's original proposal continued afterwards. In particular, Klieger does not recognize how infringement's expansion explains the development of dilution by tarnishment. See infra Part V.

243. See Pattishall, supra note 219 , at $892-93$.

244. See Brown, supra note 16 , at 1195-98. This relaxed baseline eventually became the standard. Cf. Coca-Cola Co. v. Gemini Rising, Inc., 346 F. Supp. 1183, 1190 (E.D.N.Y. 1972) (defining the ordinary purchaser as including the ignorant purchaser).

245. In this sense, Schechter's dilution proposal was not quite as radical as its detractors claim. An expansion of the consumer confusion test only looks less problematic because it was a change in degree instead of a change in kind. But a sweeping change in degree-like the one proposed by Brown-can be just as radical as developing a new framework of analysis like Schechter did.

246. See, e.g., Ringling Bros.-Barnum \& Bailey Combined Shows, Inc. v. Utah Div. of Travel Dev., 170 F.3d 449, 454 (4th Cir. 1999), cert. denied, 528 U.S. 923 (1999). 
ing an entirely new statutory regime. This reflects exactly the kind of legislative inertia that concerns modern obsolescence scholars. ${ }^{247}$ Legislative reluctance to embrace dilution in these early years, therefore, does not undermine the fact that Schechter's idea achieved a remarkable degree of attention as a way of fighting infringement obsolescence.

By the late 1940s and early 1950s, legislative patience with the common law process wore thin and states started to pass dilution statutes. Massachusetts enacted the first in 1947, and New York, Illinois, and Georgia soon followed suit. 248 In the initial stage of the trademark life cycle, courts and commentators saw dilution as an excellent way to modernize trademark protection. Yet just as dilution began to gain traction in state legislatures, the consumer confusion test started to overcome its problems.

\section{B. A QUALITY BRIDGE}

While Learned Hand did prolong the obsolescence of infringement law in Johnson, his focus on the mark owner's expansion and reputational interests was a key step in the transition to the modern confusion test. Hand and his contemporaries faced a dilemma. They knew that industrial commerce had changed the mark's primary function. They were also aware that this transformation required new thinking about the way marks were protected. But the path to a broader confusion test that did not chill competition was unclear. As a result, courts built on the foundations of existing infringement law and also contextualized the problem of quality-function protection by focusing on the quality of the junior user's products.

The first Johnson factor, the likelihood that the senior user would expand into a junior user's market, was simply an expansion of time-tested doctrine. Schechter argued in his dilution article that a mark owner should receive the broadest possible protection for the expansion of his or her trade into other product lines. ${ }^{249}$ The rationale for what we now call the "bridg-

247. See supra Part III.B.

248. See Act of May 2, 1947, ch. 307, $\$ 7 \mathrm{a}, 1947$ Mass. Acts 300 (codified as amended at MASS. GEN. LAWS ANN. ch. 110B, $\S 12$ (West 1999)); Klieger, supra note 9 , at 812 . The Illinois and Massachusetts dilution laws may well have been specifically intended to fix infringement obsolescence. See Klieger, supra note 9 , at 812 n.126.

249. See Schechter, supra note 1, at 823. 
ing the gap" element in infringement analysis is pretty obvious. Since infringement was concerned with preventing a direct competitor from using a particular mark, then the use of a mark by someone who was likely to become a direct competitor in the future could also be a logical basis for protection. All Hand's attention on bridging the gap did, therefore, was advance a somewhat broader view of the competitive relationship necessary to justify relief. This was an incremental step well within the established framework of infringement analysis. ${ }^{250}$

Hand's interest in the potential harm to the reputation of the senior user, however, was more original and presented complications that often cloud our understanding of trademark law. Since marks served a quality-identifying function, looking at the quality disparity between the junior and senior users made sense. When a junior user sells shoddy or unsavory goods, the injury to the quality function is more palpable than if the goods are similar in quality to the senior user. In the latter case, the quality consistency the mark symbolizes is undermined.251 If the junior user's goods are lousy, however, the quality information conveyed by the mark is also affirmatively diminished by the negative associations consumers might make with the senior user's products. In that case, "the disappointed expectations of buyers will presumably be vented against any article bearing the symbol. Thus the [mark owner] loses present and perhaps future sales."252 Junior good quality was also an appropriate starting point for common-law courts because it consisted of readily observable facts.

Using the quality of the junior user's products as an element of infringement analysis, however, creates an interesting paradox. While the harm to a mark owner may be greater when the junior user produces junk, that scenario actually reduces the likelihood of consumer confusion as such. ${ }^{253}$ This is because customers are less likely to believe that truly shoddy or unsavory goods come from a mark owner with an excellent

250. This step still went too far for Judge Frank. He argued that in noncompeting goods cases a mark owner "should always be required to prove that defendant's product is so substandard that, if that product be associated by consumers with plaintiff, impairment of plaintiffs good-will is a likely result." Triangle Publ'ns, Inc. v. Rohrlich, 167 F.2d 969, 981 (2d Cir. 1948) (Frank, J., dissenting).

251. See supra text accompanying note 130 .

252. See Brown, supra note 16 , at 1186.

253. See Hughes, supra note 31, at 998 (arguing that the likelihood of consumer confusion increases when the products are the same quality). 
reputation. Furthermore, there is considerable merit to the notion that, in fact, "product[s] of equal quality promote] confusion that they come from the same source." 254

When the reputation behind the senior and junior goods differs sharply, there is a legitimate question as to whether consumers will actually think that the mark owner sponsored the inferior goods. Suppose that someone sees a topless dance bar called the Kodak Lounge. For obvious reasons, this could confuse people into thinking that Kodak was somehow connected to the bar. On the other hand, the difference between the sterling (and rather dull) reputation of Kodak goods and a sleazy dance hall leads to the following persuasive argument: no reasonable person could think that a company like Kodak is in any way connected to an activity as unsavory as nude dancing. Just as unrelated products are less likely to be confused than closely related goods, it is equally true that items with unequal quality reputations are less likely to be confused than goods from owners with similar reputations for quality. At some point, the fine reputation of a senior user should make it hard for all but the most gullible to conclude that, for example, Kodak might sponsor nude dancing.

As Part V demonstrates, however, courts have consistently rejected the argument that consumer confusion is not possible because the reputations of the junior and senior users are too different. 255 In part, this is because Brown's notion that the baseline of confusion analysis should be the ignorant public rather than the reasonable consumer has been accepted. More important, courts have found confusion in these situations not because confusion is really likely, but because the injury to the mark's quality symbolism is quite serious among those who do believe that there is an association between the junior and senior marks.

Contrast this with a case where the quality of the junior and senior goods is nearly identical. Let us say that someone buys an excellent Tiffany oriental rug. ${ }^{256}$ Unbeknownst to the customer, the rug was made by a company unaffiliated with Tiffany. Since the rug is pretty good, the individual consumer walks away satisfied and suffers no short-term injury. Never-

254. Nikon, Inc. v. Ikon Corp., 987 F.2d 91, 95 (2d Cir. 1993) (emphasis added).

255. See infra Part V.

256. Assume for purposes of this hypothetical that Tiffany does not sell oriental rugs and thus that there is no direct competition. 
theless, long-term consumer confusion may well be increased. Put simply, the similarity between the real and false Tiffany goods makes it more difficult for customers to tell which one is which. On the other hand, if the false rug is shoddy (i.e., it falls apart when handled), it would be easier for customers to separate a counterfeit from the genuine article. ${ }^{257}$ Moreover, a particular mark arguably suffers a more serious harm when the junior and senior brands develop similar reputations for quality. Under those circumstances, "the consumer not only buys the counterfeit product once, but uses it and then repeatedly buys the counterfeit product" because of its high quality. ${ }^{258}$ This may be more difficult to observe than the reputational harm Hand was concerned about in Johnson, but it is nonetheless a significant potential injury.

Thus, a survey of Hand's refined infringement analysis demonstrates that the protection of the mark's quality function is best viewed along a continuum embracing two factors: potential source confusion and reputational injury. At one end of the spectrum is the case that troubled Learned Hand. This involves shoddy or unsavory junior goods, and leads to less overall confusion but a more direct injury to the mark's quality symbolism. On the other end, the reputation of the goods is indistinguishable. This creates more confusion and hurts the mark's quality role by undermining its consistency, but does not inflict an affirmative injury to the mark's reputation. Somewhere in the middle lies a zone of "no trademark protection." This is characterized by an insufficient combination of (1) some difference in the junior and senior users' reputation, and (2) some similarity between the marks and their products.

By broadening infringement beyond the old common-law approach, the quality factor of Hand's transitional formula helped move the confusion test into the modern era. Once infringement law overcame its obsolescence, however, the quality of the junior user's goods became virtually irrelevant in infringement analysis. ${ }^{259}$ Other contextual factors proved to be more helpful for courts engaged in quality-function protec-

257. Of course, the consumer may not discover the fraud until he or she has already purchased the low-quality rug. After that, however, the difference between the false Tiffany and genuine items will be more obvious.

258. Hughes, supra note 31 , at 998.

259. See, e.g., Triumph Hosiery Mills, Inc. v. Triumph Int'l Corp., 308 F.2d 196, 199 (2d Cir. 1962); see also infra text accompanying notes 296-98. 
tion. ${ }^{260}$ Yet the transitional step to the modern confusion test (quality examination) would soon graft itself onto Schechter's transitional remedy (dilution) to produce a new form of dilution totally unrelated to Schechter's proposal (tarnishment). 261 These connections are explained further in Part V, but first let us see how courts grappled with the meaning of infringement and dilution in the immediate aftermath of Johnson.

\section{SCHISM IN THE SECOND CIRCUIT}

Before a reformed consumer confusion test could spring forth from its cocoon, the Second Circuit had to weather a serious split between those who read Johnson broadly to modernize trademark law and those who construed the case in line with more traditional principles. As one commentator observed,

Judges Learned Hand and Jerome Frank espoused the view that trademark protection should be sparingly, if at all, applied to protect uses on non-competitive goods. They feared creating a judge-made "monopoly" in trademarks. Judges [Charles] Clark and Augustus Hand generally favored application of the broad "related goods" test of the old ... Yale case[. Judges Swan and Chase sometimes went with the Learned Hand-Frank faction, sometimes to the Clark-Augustus Hand camp. ${ }^{262}$

The schism within the Court was just part of the difficult effort to develop the contours of a new confusion test. For litigants, however, an unfortunate side effect was that the outcome of infringement cases during the 1940s and 1950s often depended entirely on which panel was sitting. ${ }^{263}$

The broad reading of Johnson was exemplified by Triangle Publications, Inc. v. Rohrlich. ${ }^{264}$ That decision affirmed a finding of likely confusion in an infringement suit brought by the publisher of Seventeen magazine against a girdle manufacturer named "Miss Seventeen Foundations Co."265 The majority opinion by Augustus Hand (joined by Judge Clark) held that the

260. See supra text accompanying notes 50-52 (discussing factors relevant to likelihood of confusion).

261. See infra Part V.B.

262. 4 MCCARTHY, supra note 10, § 24:56 (footnotes omitted).

263. See Hyde Park Clothes, Inc. v. Hyde Park Fashions, Inc., 204 F.2d 223, 226 (2d Cir. 1953) (Clark, J., dissenting); 4 MCCARTHY, supra note 10, § 24:56 (footnotes omitted). At that time, the Second Circuit frowned on hearing cases en banc, which would have been an obvious way to heal the court's split.

264. 167 F.2d 969 (2d Cir. 1948) (A. Hand, J.), overruled on other grounds by Monsanto Chem. Co. v. Perfect Fit Prod. Mfg. Co., 349 F.2d 389 (2d Cir. 1965).

265. See id. at 970 . 
numerous advertisements in the magazine for women's clothing items could lead consumers to conclude that the plaintiff was affiliated with the defendant's girdles. ${ }^{266}$ In the majority's view, this "would necessarily be at the risk of the plaintiffs reputation ... [because] the erroneously supposed sponsorship of the plaintiff would injure [its] reputation if goods sold by the defendants were inferior to the high quality which the public attributed to the goods actually advertised in or commented upon by the magazine."267

Judge Frank's dissent argued that Triangle marked "the farthest that the courts have been asked to extend the reach of the unfair competition trade-name doctrine."268 Applying the Johnson framework narrowly, he first argued that there was no possibility that the magazine publisher would ever enter the girdle market. ${ }^{269}$ Second, Frank observed that the majority could not properly grant relief just because the junior user's goods might have a shoddy reputation. ${ }^{270}$ Instead, the plaintiff had to prove "that defendant's goods are of a quality inferior to those advertised in plaintiff's magazine."271 Since plaintiff had offered no such proof, Frank concluded that an infringement action could not be sustained. ${ }^{272}$

On the other side we find Hyde Park Clothes, Inc. v. Hyde Park Fashions, ${ }^{273}$ in which a majority comprised of Judges Swan and Frank found no likelihood of confusion between "Hyde Park" men's suits and "Hyde Park" women's clothing. 274 The court gave short shift to the plaintiffs contentions on appeal. In a brief discussion, the majority held: (1) that the parties made different kinds of clothes and hence were not in direct competition; (2) that there was no evidence that the defendant's clothes were inferior to the plaintiffs; and (3) that there was no evidence that the plaintiff would expand into women's clothing. ${ }^{275}$

266. See id. at 972 .

267. Id.

268. Id. at 974 (Frank, J., dissenting).

269. See id. at 975.

270. Indeed, Frank's view was far more restrictive. See supra note 250.

271. See Triangle, 167 F.2d at 981.

272. See id.

273. 204 F.2d 223 (2d Cir. 1953) (Swan, J.).

274. See id. at 224.

275. See id. at 224-26. 
This time Judge Clark was the dissenter, and he lamented that "[p]laintiff-appellant has had the misfortune-so it seems to me-to come before a panel of this court allergic to the [goods] doctrine historically associated with us ... of protecting trade names against competition which will create confusion as to the source of goods sold under such names." 276 He pointed out that the parties were both in "the garment industry," which were more closely related than the razor blades and pens at issue in the Waterman case. ${ }^{277}$ While Clark did implicitly concede that the Johnson elements were not met by ignoring the issue, he concluded that it "cannot really be in doubt" that consumer confusion was likely in this non-competing goods case. ${ }^{278}$ He reached this result, in part, by relying on several other contextual factors (such as the distinctiveness of the marks and their length of time in use) that foreshadowed the Polaroid test. 279

The long, divisive struggle to work out a new consumer confusion test ended by the early 1960s in favor of those who supported broad protection. In Polaroid, Judge Friendly used dicta to propose his famous eight-factor formula for infringement analysis.280 A less noteworthy facet of this landmark opinion was its effort to synthesize the competing views within the Second Circuit.281 Friendly's approach included the two Johnson factors, bridging the gap and reputational injury, along with additional elements that had been on display in the opinions of those who did not agree with Johnson.282 By reorganizing infringement in this fashion, Friendly brought down the curtain on a long-running show that had started with Schechter's observation of trademark law's obsolescence. The confusion test was on the verge of being reborn.

\section{DILUTION RETREATS}

Given the link between dilution and infringement in Schechter's original proposal and in subsequent decades, it should come as no surprise that dilution law began its long hi-

276. Id. at 226 (Clark, J., dissenting).

277. See id. at 229.

278. See id.

279. See id.

280. See Polaroid Corp. v. Polarad Elecs. Corp., 287 F.2d 492, 495 (2d Cir. 1961) (Friendly, J.).

281. See 4 MCCARTHY, supra note 10, § 24:57.

282. See Hyde Park, 204 F.2d at 229 (Clark, J., dissenting). 
bernation just as the modern confusion test emerged in the late 1950 s and early $1960 \mathrm{~s} .{ }^{283}$ One of the leading cases on dilution's retreat was Esquire, Inc. v. Esquire Slipper Mfg. Co. ${ }^{284}$ in which the First Circuit read the Massachusetts dilution statute to require a likelihood of confusion despite the law's express rejection of such a requirement. ${ }^{285}$ The court reached this rather astounding result by reasoning that the dilution statute simply expanded infringement protection into non-competing goods cases by getting rid of the old common law rule that only direct competitors were liable for infringement. ${ }^{286}$ Massachusetts courts took a similarly narrow view of their state dilution remedy. ${ }^{287}$ The same strangulation of dilution took place in New York. ${ }^{288}$ Commentators like Pattishall grumbled that New York and federal courts "stubbornly and illogically" read confusion requirements into that state's dilution law. ${ }^{289}$

These restrictive readings of dilution statutes were probably driven by concerns about overshooting. ${ }^{290}$ Once infringement escaped from its obsolescence, courts no longer needed di-

283. See Klieger, supra note 9, at 815-16. The Seventh Circuit's favorable treatment of the Illinois anti-dilution statute appears to be an exception to this trend. See Polaroid Corp. v. Polaraid, Inc., 319 F.2d 830 (7th Cir. 1963). This case involved Polaroid's infringement and dilution suit against a refrigerator maker. See id. at 832. A panel majority (over a strong dissent) held that the plaintiff was entitled to relief under infringement and dilution (blurring) theory. See id. at 836-37; id. at 837 (Schnackenberg, J., dissenting).

Upon closer examination, however, the case actually supports an obsolescence reading of dilution. The district court in this Polaroid case ruled against the plaintiff because there was no evidence of actual confusion and because the parties were not in direct competition. See id. at 835 . To remedy this cramped view of trademark protection, the panel majority used dilution to buttress their infringement arguments much like courts did in the years following the publication of Schechter's article. See generally White v. Samsung Elecs America, Inc., 989 F.2d 1512 (9th Cir. 1993). Interestingly, Polaroid used dilution in this way even though the Illinois statute had never been interpreted by a state court. See Polaraid, 319 F.2d at 836 .

284. 243 F.2d 540 (1st Cir. 1957).

285. See Act of May 2, 1947, ch. 307, $\S 7$ a, 1947 Mass. Acts 300 (codified as amended at MASS. GEN. LAWS. ANN. ch. 110B, $\S 12$ (West 1996)); Esquire, 243 F.2d at 544.

286. See Esquire, 243 F.2d at 542-43; Klieger, supra note 9, at 818-19 \& n.157; Note, supra note 10, at 526.

287. See Note, supra note 10 , at 527.

288. See Cue Publ'g Co., Inc. v. Colgate-Palmolive Co., 256 N.Y.S.2d 239, 246 (N.Y. Sup. Ct. 1965) (collecting authorities).

289. See Pattishall, supra note 21, at 624 .

290. See Ringling Bros.-Barnum \& Bailey Combined Shows, Inc. v. Utah Div. of Travel Dev., 170 F.3d 449 (4th Cir. 1999), cert. denied, 528 U.S. 923 (1999). 
lution to extend trademark protection. As a result, the application of dilution statutes with their extraordinarily broad language was now viewed with great skepticism. Courts therefore tried to make sense of dilution in this post-obsolescence environment by fitting them into the familiar framework of infringement. This inevitably meant reading consumer confusion requirements into dilution laws even though those statutes expressly disavowed a confusion limitation. Violating this most basic canon of statutory construction (i.e., reading the statute's text) has been viewed by dilution supporters as an act of bad faith.

If dilution is read as an obsolescence remedy, however, the rough treatment given to the concept during this period looks much better. To the extent that dilution was about fixing infringement's obsolescence, those laws no longer had a purpose by the eve of the Polaroid decision. While dilution laws provided courts with ample room to expand trademark protection in marginal non-competing cases, their continued application would lead to overshooting by pushing protection too far ahead of the legitimate needs of commercial life.

Unlike other kinds of obsolete laws, however, dilution could not be harmonized with the surrounding legal and pragmatic landscape through ordinary interpretive techniques. Reading the statute literally, an approach used to deal with obsolete banking statutes, would not solve dilution's overshooting difficulties because the literal text of dilution laws was the problem.291 There were also no administrative agencies available to have interpretive discretion delegated to them. In the end, the only principled way to read dilution was the counterintuitive approach of borrowing the confusion requirement from infringement doctrine and then applying it to dilution, notwithstanding the contrary text of dilution laws. ${ }^{292}$

From the 1920s until the 1960s, the fates of dilution and infringement were inextricably intertwined. Instead of establishing a new model of protection as Schechter intended, courts used dilution as an infringement obsolescence remedy whose vitality was entirely dependent on the status of infringement law. As a result, dilution and infringement moved inversely to

291. See Langevoort, supra note 197, at 715.

292. This approach could be construed as a kind of "dynamic statutory interpretation." See ESKRIDGE, supra note 201, at 112. That theory, however, contemplates giving statutes broad readings to alleviate obsolescence, not narrow readings to avoid overshooting. 
each other throughout this period. The next Part examines how dilution took on a different, but related, role during an era when infringement was basically up to the task of protecting marks.

\section{TARNISHMENT UPON THE RUINS OF CHANGE}

This Part shows how a new form of dilutiontarnishment-evolved from the transitional infringement test Learned Hand set forth in Johnson. After modern consumer confusion analysis developed, the quality disparity between junior and senior goods became relatively unimportant in infringement cases. Instead, courts gradually used Hand's quality factor to identify the tarnishment of a mark's reputation as a harm distinct from confusion. This makes tarnishment a direct descendant of the approach that helped infringement overcome its obsolescence. Accordingly, tarnishment is closely related to dilution's overall role as the transitional law of trademark, even though it looks nothing like Schechter's original proposal. Following an examination of the development of dilution law since the 1960 s, this section concludes by articulating some principles to guide courts in dilution cases.

\section{A. CONSOLIDATION IN INFRINGEMENT}

The Second Circuit turned Judge Friendly's brilliant dicta in Polaroid into a holding in Triumph Hosiery Mills, Inc. $v$. Triumph International Corp. ${ }^{293}$ Triumph presented the question of whether either condition specified by Hand in Johnson, bridging the gap or reputational injury, were still necessary for an infringement violation after Polaroid. The court answered this question in the negative:

The Polaroid summary recognizes that the reach of the trade-mark beyond its owner's present use depends upon factors which are variable and relative, none of which standing alone constitutes the sole criterion. In this, the Polaroid summary is not in conflict with the Johnson opinion. For in Johnson, Judge Hand strongly intimated that the two limiting conditions of the [non-competing] goods doctrine are in themselves not indispensable absolutes but rather relative variables. ${ }^{294}$

This statement was a classic judicial sleight-of-hand. Hand's second opinion in Johnson, in fact, stated quite clearly that in non-competing goods cases infringement doctrine "rec-

293. 308 F.2d 196 (2d Cir. 1962).

294. Id. at 198. 
ognizes two, but only two, interests on which the [mark] owner can stand."295 Nevertheless, Triumph acted appropriately in casting aside Johnson's more limited framework since Hand's language on this point did not constitute a holding.

Once a senior user no longer needed to show reputational harm in order to get relief, the quality factor in infringement analysis simply withered away. The underlying rationale of Hand's quality test was forgotten to such an extent that today courts applying the Polaroid framework find it hard to see exactly how the quality element cuts. ${ }^{296}$ For instance, the Second Circuit has recently explained that "[w]e have taken two approaches about the quality of the junior user's product: (1) an inferior quality product injures the senior user's reputation because people may think they come from the same source; or (2) a product of equal quality promotes confusion that they come from the same source."297 In other words, the quality prong is meaningless; it can be used with equal force to support or reject a finding of likely consumer confusion. This simply restates the paradox of using quality as a part of infringement analysis. ${ }^{298}$ While a quality disparity between the junior and senior user leads to less potential confusion, that same situation still injures the mark's quality-representing function because the mark's reputation is affirmatively harmed among those who do think the goods come from the same source.

Since Polaroid established more reliable factors to evaluate when the mark's quality-representing function needed protection, courts quietly put Hand's more problematic analysis out to pasture. Yet his effort to lift infringement from its obsolescence lives on through dilution. Tarnishment is the Hand quality test applied with a vengeance.

295. S.C. Johnson \& Son, Inc. v. Johnson, 175 F.2d 176, 179-80 (2d Cir. 1949) (L. Hand, C.J.) (emphasis added).

296. See Nikon, Inc. v. Ikon Corp., 987 F.2d 91, 95 (2d Cir. 1993). Indeed, many circuits have adopted the basic Polaroid framework while declining to include product quality as a factor in their analysis. See, e.g., Keds Corp. v. Renee Int'l Trad. Corp., 888 F.2d 215, 222 (1st Cir. 1989); Pizzeria Uno Corp. v. Temple, 747 F.2d 1522, 1527 (4th Cir. 1984); AMF Inc. v. Sleekcraft Boats, 599 F.2d 341, 348 (9th Cir. 1979).

297. Nikon, 987 F.2d at 95.

298. See Part IV.B (analyzing the use of quality as a part of infringement analysis). 


\section{B. TARNISHMENT OUT OF CONFUSION}

Although courts no longer needed a sharp disparity between junior and senior quality to grant trademark protection, questions remained as to how courts would now handle trademark claims involving vastly inferior junior products. One of the first cases to present the problem after Polaroid was Chemical Corp. of America v. Anheuser-Busch, Inc. ${ }^{299}$ This infringement suit pitted Budweiser beer, which at that time used the marketing slogan "Where there's life... there's Bud," against a manufacturer of a floor wax/insecticide sold under the catch-phrase "Where there's life ... there's bugs." 300 The Fifth Circuit granted relief to the plaintiff "both by reason of confusing the source of the defendant's product, and by reason of the peculiarly unwholesome association of ideas when the word 'bugs' was substituted in the slogan for the word 'Bud,' referring to a food product."301 Put another way, the court construed likely consumer confusion (i.e., harm to the mark's quality consistency) and reputational injury (i.e., affirmative injury to the mark's quality reputation) as separate harms that could each warrant protection under certain circumstances. ${ }^{302}$ By identifying these two distinct strands of the quality function, the court set the stage for the subsequent divorce of tarnishment from infringement.

The Chemical decision was the centerpiece in the next critical juncture for dilution law, and the forum was once again the Harvard Law Review. This time, however, the catalyst for change was an anonymous student Note instead of a Schechter article..$^{303}$ In a piece entitled Dilution: Trademark Infringement or Will-O'-The-Wisp, the author set out to "inquire into the interest protected by the dilution doctrine, examine the scope of protection hitherto afforded it, and attempt to evaluate the de-

299. 306 F.2d 433 (5th Cir. 1962).

300. Id. at 434. Since the defendant's product was both an insecticide and a floor cleaner, presumably the defendant did not tell consumers that their kitchen floors would be made so clean that they could eat off them.

301. Id. at 437 (emphasis added).

302. See also Tiffany \& Co. v. Boston Club, Inc., 231 F. Supp. 836, 843 (D. Mass. 1964) (holding that consumer confusion and reputational injury were caused by a restaurant's use of "Tiffany," since the restaurant served cheap meals and placed newspaper advertisements on the same page as ads for "Any Man's Woman," "Not Tonight, Henry," "The Horror Chamber of Dr. Faustus," "Illicit Love," "The Stripper," and "Bozo the Clown").

303. See Note, supra note 10. 
sirability of expanding protection."304 As this effort was undertaken during an era when dilution was disfavored, the author had to struggle against many hostile court decisions. ${ }^{305}$ Nevertheless, the Note took the position that dilution remained a useful remedy.

The Fifth Circuit's holding on the injury caused by a junior user's unwholesome products led the Note to conclude that dilution had a legitimate role to play in preventing tarnishment. As the author described the problem in Chemical, "[T] heuser-Busch Company might well object to use of its trade name on inferior products, or on products like toilet seats or rat poison whose very nature creates associations capable of reducing consumer acceptance of its beer."306 Basically, this statement just repeats Hand's original reasoning for looking at junior-use quality. What the Note failed to mention was that Chemical did provide protection to Busch on infringement grounds. The case had nothing to do with dilution.

Nevertheless, the Note turned Chemical's analysis of the second strand of the quality function-affirmative reputational injury-into a second strand of dilution theory. According to the Note, "[D]ilution threatens two separable but related components of advertising value. Junior uses may blur a mark's product identification, or they may tarnish the affirmative associations a mark has come to convey." 307 This was the first and most influential formulation of dilution's tarnishment prong. ${ }^{308}$ Yet, as a careful examination makes plain, tarnishment was actually descended from Hand's quality test in Johnson. The Note took a concept designed to fix infringement's obsolescence and merged it with a remedy whose main purpose was curing infringement obsolescence. As a result, tarnishment does fit within the dilution framework despite commentary to the con-

304. Id. at 521.

305. See supra Part IV.D (discussing the period of dilution's retreat in case law).

306. Note, supra note 10 , at 522.

307. Id. at 531 (emphasis added).

308. Of course, the idea of tarnishment was hinted at in the Yale opinion, but that statement was not given any explanation. See supra text accompanying note 232.

At about the same time that the Harvard Note was published, a district court in Massachusetts independently replicated the Note's analysis and placed tarnishment under the rubric of dilution. See Tiffany \& Co. v. Boston Club, Inc., 231 F. Supp. 836, 843 (D. Mass. 1964). 
trary.309 The connection between tarnishment and the rest of dilution, however, becomes apparent only when dilution is read through an obsolescence prism.

Although the Harvard Note defined tarnishment as a form of dilution, many courts continued to use infringement to analyze cases presenting significant quality disparities between the junior and senior goods. ${ }^{310}$ These decisions used tarnishment language to support their conclusions and are today usually cited as tarnishment cases. ${ }^{311}$ Courts in these situations needed tarnishment to extend protection because of the paradox created by using a quality focus to ascertain potential consumer confusion. When junior users complained that no consumer could possibly think that their sleazy product was associated with the senior user's excellent reputation, courts refuted this through tarnishment. This use of tarnishment to supplement infringement mirrors the behavior of the courts in the 1930s and 1940s that used dilution to buttress their holdings in marginal infringement cases. ${ }^{312}$

Let us look at some of these proto-tarnishment cases. In Coca-Cola Co. v. Gemini Rising, Inc., 313 the district court granted relief to Coca-Cola against a defendant that sold posters resembling the Coca-Cola logo and bearing the words "Enjoy Cocaine."314 The defendant used the familiar argument that there was not "any reasonable likelihood, considering the nature of the poster, that anyone could or would be confused as to [its] origin." 315 The court cited some evidence of confusion, but

309. See Part II.D.1.

310. The fluid state of trademark law at this time is demonstrated by Cue Publishing Co. v. Colgate-Palmolive Co., 256 N.Y.S.2d 239 (N.Y. Sup. Ct. 1965). Plaintiff "Cue" magazine brought infringement and dilution claims in state court against the manufacturer of "Cue" toothpaste. See id. at 240. The court rejected the plaintiffs suit. See id. at 247 . In analyzing the case, the court treated infringement, tarnishment, and dilution as separate heads of trademark protection, with dilution referring only to Schechter's proposal. See $i d$. at 243 . The point is that tarnishment could easily have developed as a third component of trademark protection alongside infringement and dilution rather than as part of dilution itself. The Harvard Note, however, proved more influential than the Cue decision.

311. See, e.g., Deere \& Co. v. MTD Prods., Inc., 41 F.3d 39, 43 n.7 (2d Cir. 1994) (citing Gemini and Busch as tarnishment cases).

312. See supra text accompanying notes 219-29 (highlighting court cases seeking an expansion of trademark protection in non-competing goods cases).

313. 346 F. Supp. 1183 (E.D.N.Y. 1972).

314. See id. at 1187.

315. Id. at 1188 . 
the heart of its analysis was that the association of "such a noxious substance as cocaine with plaintiffs wholesome beverage as symbolized by its 'Coca-Cola' trademark and format would clearly have a tendency to impugn that product and injure plaintiffs business reputation."316 This was particularly true in Coca-Cola's case because "[t]he soft drink industry is highly competitive. Many substitute products are available, so that even the slightest negative connotation concerning a particular beverage may well affect a consumer's decision."317

A more colorful example of an infringement case that is now commonly cited as a tarnishment precedent is Dallas Cowboys Cheerleaders, Inc. v. Pussycat Cinema, Ltd. ${ }^{318}$ The cheerleaders, who are known for their lack of attire, sued the producers of what the court described as "a gross and revolting sex film" involving the fictional "Texas Cowgirl" cheerleaders. ${ }^{319}$ Once again, the junior user argued that no reasonable person could possibly confuse a pornographic film with the cheerleaders. ${ }^{320}$ Relying on Gemini and Anheuser-Busch, the court sided with the plaintiffs and, through tarnishment rhetoric, found likely consumer confusion. ${ }^{321}$ The panel explained that the cheerleaders had a right to control their reputation, and "it is hard to believe that anyone who had seen defendants" sexually depraved film could ever thereafter disassociate it from plaintiffs cheerleaders."322 This association had "a tendency to impugn [plaintiff's services] and injure plaintiff's business reputation." 323

Eventually, courts abandoned the pretense that cases like Gemini and Dallas fit the confusion rationale, and tarnishment became a separate component of dilution. Here are some of the bizarre fact-patterns that have supported tarnishment findings: (1) the display of the Pillsbury "Poppin' Fresh" character in various explicit sexual positions;"324 (2) the "Garbage Pail

316. Id. at 1189 .

317. Id. at 1190.

318. 604 F.2d 200 (2d Cir. 1979).

319. Id. at 204.

320. Id. at 205.

321. Id.

322. Id. (quoting Gemini, 346 F. Supp. at 1189).

323. Id.

324. Pillsbury Co. v. Milky Way Prods., 215 U.S.P.Q. 124, 135 (N.D. Ga. 1981). 
Kids" parody of "Cabbage Patch Kids" dolls;325 (3) a stand-up comedian named Kodak who told off-color jokes;326 (4) the use of a savings and loan mark by a topless bar;"327 and (5) "Gucchi Goo" diapers. ${ }^{328}$ These cases followed the pattern set by the earlier confusion/tarnishment decisions and focused on the quality difference between the senior and junior users.

\section{BLURRING AND OTHER OVERSHOOTING}

While courts fashioned a new understanding of dilution from the remnants of infringement's transition, Schechter's idea of dilution, now called blurring, remained dormant. 329 As we saw earlier, following the reform of the consumer confusion test, courts pushed Schechter's theory into the shadows as part of an unconscious yet concerted effort to avoid overshooting the appropriate level of trademark protection. Over time, however, the circumstances that originally gave rise to dilution faded from judicial memory. What remained were the broad dilution laws and Schechter's original explanation for them. This combination enhanced the risk of overshooting.

The revival of blurring is usually traced to the New York Court of Appeals' decision in Allied Maintenance Corp. $v$. Allied Mechanical Trades, Inc., 330 in which the court removed the consumer confusion requirement that was previously read into the state anti-dilution statute. ${ }^{331}$ Plaintiff was a service company that cleaned and maintained large office buildings, while the defendant was in the air-conditioning and heating business. ${ }^{332}$ Although Allied rejected the plaintiff's dilution claim, the opin-

325. Original Appalachian Artworks, Inc. v. Topps Chewing Gum, Inc., 642 F. Supp. 1031, 1038-39 (N.D. Ga. 1986).

326. Eastman Kodak Co. v. D.B. Rakow, 739 F. Supp. 116118 (W.D.N.Y. 1989).

327. Cmty. Fed. Sav. \& Loan Ass'n v. Orondorff, 678 F.2d 1034 (11th Cir. 1982).

328. Gucci Shops, Inc. v. R.H. Macy \& Co., 446 F. Supp. 838, 839, 40 (S.D.N.Y. 1977).

329. During this period of dormancy dilution statutes were enacted in additional states to extend additional protection to mark owners. See Howard J. Shire, Dilution Versus Deception-Are State Antidilution Law an Appropriate Alternative to the Law of Infringement?, 77 TRADEMARK REP. 273, 285 (1987) ("[T]he dilution statutes had very little impact on trademark law for approximately the first 30 years of their existence."). Nevertheless, these laws were quickly eviscerated by the courts in those states.

330. 369 N.E.2d 1162 (1977).

331. See id. at 1165.

332. See id. at 1163. 
ion argued that imposing a confusion requirement in dilution actions simply ignored the language of the statute. ${ }^{333}$ The Court of Appeals may have done a more honest job of statutory construction than its predecessors, but Allied was not particularly sensitive to the broader problems of trademark law. Resurrecting blurring at a time when there was no gap in infringement protection deepened the overshooting trap. Following the decision in Allied, however, courts began to take dilution claims more seriously.

Periodically, courts make the mistake of applying Schechter's concept literally, and in so doing come very close to granting mark owners a property right in gross. 334 One example is Dawn $v$. Sterling Drug, Inc., ${ }^{335}$ in which the plaintiff owned the mark "Tower of Babble" and over a period of several years spent a total of $\$ 600$ on advertising to market a children's word game with that name. ${ }^{336}$ Defendant produced Bayer Aspirin and used the phrase "tower of babble" in advertising captions. ${ }^{337}$ The district court found no evidence of likely consumer confusion, no evidence that plaintiffs business had been damaged, and that the plaintiff had sold only 4000 games in eight years of business. ${ }^{338}$ Nevertheless, "out of an abundance of fairness" the court enjoined defendant's use of the mark on dilution grounds. ${ }^{339}$ Whether, under the circumstances, the plaintiff really deserved relief for a clever alteration of the biblical "Tower of Babel" is highly questionable. The decision is classic overshooting: a literal application of dilution that removes phrases from the commercial market for no good reason.

A slightly different overshooting example comes from the humorless decision of Deere \& Co. v. MTD Products, Inc., 340 where the plaintiff produced agricultural machinery and used a proud buck as its mark. ${ }^{341}$ Defendant, a direct competitor, produced a commercial in which a buck runs away in fear from de-

333. See id. at 1165.

334. See, e.g., Wedgwood Homes, Inc. v. Lund, 659 P.2d 377, 382-83 (Or. 1983) (finding the local trademark Wedgwood Homes blurred by Wedgwood apartments and retirement communities).

335. 319 F. Supp. 358 (C.D. Cal. 1970).

336. Id. at 360 .

337. Id. The phrase was meant to describe the confusing claims of competing pain relievers. Id.

338. Id. at $360,363$.

339. Id. at 363 .

340. 41 F.3d 39 (2d Cir. 1994).

341. See id. at 41 . 
fendant's lawn mower and a barking dog. ${ }^{342}$ The Second Circuit ruled that, by ridiculing the Deere buck, the defendant was liable under New York dilution law because the commercial created "the possibility that consumers will come to attribute unfavorable characteristics to a mark and ultimately associate the mark with inferior goods and services." 343 This reasoning comes dangerously close to prohibiting comparative advertising. It is one thing to bar junior uses that just wound the reputation of the mark owner. Quite a different situation is presented when a junior user, in this case a direct competitor, employs parody as a way of convincing consumers to choose its products over a rival's goods. ${ }^{344}$ Again, Deere took the language of dilution literally, and thereby extended trademark protection too far. A more coherent framework of analysis is required to preserve dilution's legitimate function and avoid overshooting.

\section{TOWARD A NEW UNDERSTANDING OF DILUTION}

The foregoing discussion of trademark doctrine sets a foundation to establish principles for the appropriate use of dilution. Of course, this cannot purport to be an exhaustive list of guidelines, but over the past seventy years clear patterns have emerged from the interplay of infringement and dilution.

\section{Transition}

The raison d'etre of dilution is remedying systemic obsolescence in trademark protection. Using dilution as a transitional force is justified, however, only when marks take on a significant new function due to sweeping economic and technological innovations analogous to those seen during the Industrial Revolution. The sheer magnitude of the structural transformation that must precede a revision in the mark's role should clarify when dilution can be used in a transitional fashion and when dilution should not be used in this way. Before the Inter-

\section{See id.}

343. Id. at 45. Deere declined to characterize its holding as either blurring or tarnishment. See id. at 44. Subsequently, Deere has been read as a broad tarnishment case. See Hormel Foods Corp. v. Jim Henson Prods., Inc., 73 F.3d 497, 507 (2d Cir. 1996).

344. Pushing the Deere logic a little further, presumably competition between two businesses that results in the bankruptcy of one would be an actionable tort. After all, the bankrupt firm has suffered damages that can be traced to a specific cause-in-fact (i.e., the competitor). The absurdity of this result applies just as well to decisions that turn comparative advertising into a trademark violation. 
net appeared on the scene, there had not been a plausible rationale in recent decades for using dilution as an obsolescence cure. The question of whether the Information Age gives courts a reason to engage in the widespread use of transitional dilution is addressed in Part VI.

But if dilution extends protection in situations where infringement has fallen short, what stops courts from simply taking the more direct approach and adapting the consumer confusion test on the spot? This question presents a classic jurisprudential problem. Many have argued that exposing a legal fiction like dilution inevitably renders that fiction ineffective, that "[w]e must not let in daylight upon magic." ${ }^{455}$ Even if dilution is revealed as an infringement supplement, however, that does not diminish its value. ${ }^{346}$ Without such a remedy, courts would be forced to articulate a coherent rationale for major adjustments to infringement doctrine in the first instance. This is not necessary or desirable. As Cass Sunstein has argued, judges confronting significant technological change are better off relying on incomplete theories (i.e., minimal explanation) that solve concrete problems while giving future courts as much flexibility as possible. ${ }^{347}$ Because of its breadth, dilution by blurring remains an effective tool for courts seeking to protect marks during periods of legal uncertainty without establishing infringement precedents that could create future problems. But this is the only situation in which the use of blurring doctrine is appropriate. ${ }^{348}$

345. WALTER BAgEHOT, THE ENGLISH CONSTITUTION 53 (Oxford University Press 1963) (1867); see also HENRY SUMNER MAINE, ANCIENT LAW 24-30 (Oxford University Press 1931) (1861) (describing legal fictions).

346. Of course, there is a separate question of whether more dilution statutes ought to be enacted once their dependent role in trademark protection is clear. Right now, the discussion is focused on how an obsolescence reading of dilution influences its application by courts.

347. See generally Cass R. Sunstein, The Supreme Court, 1995 TermForeword: Leaving Things Undecided, 110 HARV. L. REV. 4 (1996).

348. Other cases that have relied on blurring, but are not clear examples of overshooting are more properly understood as likelihood of confusion cases. See Nabisco, Inc. v. PF Brands, Inc, 191 F.3d 208, 219 (2d Cir. 1999); Ringling Bros.-Barnum \& Bailey Combined Shows, Inc. v. Celozzi-Ettelson Chevrolet, Inc., 855 F.2d 480, 484 (7th Cir. 1988); Hyatt Corp. v. Hyatt Legal Servs., 736 F.2d 1153, 1156-58 (7th Cir. 1984); Instrumentalist Co. v. Marine Corps League, 509 F. Supp. 323, 330-33 (N.D. Ill. 1981). 


\section{Tarnishment}

Tarnishment is the second category of dilution. As the heir to the quality focus that aided infringement in its period of transition, tarnishment looks at the disparity between junior and senior reputations to determine whether the qualityidentifying function of the mark is substantially impaired. Courts need tarnishment because there will be situations in which the quality gap between the mark users is so wide that it becomes problematic to find that consumers could be "confused" as that term is ordinarily understood. Although there are not enough tarnishment cases to draw any clear lines, at a minimum it can be said that the quality or reputational disparity between the senior and junior uses must be obvious before relief can be granted. Few cases will meet this stringent standard. ${ }^{349}$

\section{The FTDA Standard of Proof}

To illustrate how these general principles can aid courts in dilution cases, let us reexamine the vexing question of what standard of proof the FTDA requires. Broadly speaking, there are two competing interpretations of the plaintiffs burden in a dilution case. 350 Some circuits hold that proof offered on a variety of contextual factors (which vary from circuit to circuit) is sufficient. ${ }^{351}$ Other circuits, however, have held that a plaintiff must prove "actual dilution" of a mark through rigorous economic or survey evidence that can only be supplemented by contextual evidence. 352 The more liberal reading of the FTDA relies heavily on the notion that an actual dilution standard would make it virtually impossible for a plaintiff to prevail. .53 Meanwhile, the latter interpretation is based on textual language in the statute stating that plaintiffs must show that an

349. One idea embedded in the Gemini case probably deserves more attention. Gemini suggested that tarnishment was more likely if there were many different substitutes for the senior user's product. See supra text accompanying note 317 . Presumably, this is because even the slightest injury to such a company's mark (e.g., Coca-Cola) could cause significant shifts in consumer behavior. This should be contrasted with companies that have a more exclusive and secure market niche, and whose marks must be harmed quite seriously before customer preferences are altered. Whether this contextual factor proves helpful in tarnishment litigation, however, remains to be seen.

350. See supra Part II.D.2.

351. See supra Part II.D.2.

352. See supra Part II.D.2.

353. See supra Part II.D.2. 
unauthorized use "causes dilution."354 Moreover, the actual dilution standard reflects the traditional hostility of infringement proponents toward the breadth of dilution theory.

These competing views resonate with important themes of this Article. It is true that an actual dilution standard would impose an overwhelming barrier to dilution plaintiffs. It is also true, however, that dilution should be difficult to prove in order to prevent the "overshooting" of the proper level of trademark protection. But, as we have seen, there are times when infringement law becomes obsolete and dilution must be more readily available as a way of extending transitional protection. Under these circumstances, plaintiffs should face the lower burden of proof created by allowing claims to be established through evidence on purely contextual factors. Balancing these competing interests requires a subtle interpretation of the FTDA. A rule mandating a single standard of proof in all dilution cases would be unwise.

The best interpretive approach would hold that plaintiffs are required to prove actual dilution unless special equitable circumstances are present, in which case evidence on certain contextual factors could be sufficient. Those special circumstances should be defined in accord with the obsolescence concerns that motivated Schechter's original proposal and have driven dilution law in the states. ${ }^{355}$ Since the text and legislative history of the FTDA offer so little guidance to courts, the state law background against which the FTDA was enacted is critical in shaping how dilution should be construed. And the evolution of state dilution law suggests that, most of the time, a high burden should be placed on the dilution cause of action. In the presence of infringement obsolescence, however, courts must permit the application of a lower standard of proof so that dilution can fulfill its purpose of preventing a substantial impairment of mark functions.

To some extent, this nuanced interpretation of the FTDA has already gained support. Notably, the Fourth and Fifth Circuit decisions construing the FTDA as requiring proof of actual

354. See supra Part II.D.2.

355. Since dilution serves primarily as an infringement supplement, it follows that a dilution analysis should incorporate all of the elements of the likelihood of confusion test. See supra text accompanying notes 51-52. Not all of these factors may be relevant in a transitional context, but that will depend on the circumstances of each transition. 
dilution arose in a non-Internet context. ${ }^{356}$ Since there is currently no infringement obsolescence in real space, the imposition of an actual dilution standard there is appropriate. Imposing such a high burden of proof in Internet trademark cases, however, may be counterproductive if, as the next section argues, dilution can have a useful role in addressing infringement obsolescence in cyberspace. Accordingly, no circuit has read the FTDA as requiring an actual dilution construction in an Internet-related case.

Elaborating principles from a fixed past is one thing. The real test comes when these principles are called upon to analyze recent controversies in trademark law. So, without further adieu, let us jump into cyberspace.

\section{TRADEMARK.COM: LOCATION, LOCATION, LOCATION}

The Internet has done more than create boom-and-bust stocks. This Part explains how e-commerce has given trademarks an important role as identifiers of retail location. ${ }^{357}$ As marks underwent their latest transformation, dilution returned from exile to serve its transitional protective function. In the wake of dilution's comeback, however, there are already clear signs that the consumer confusion test is adapting to the demands of the Information Age.

\section{A. A THIRD DIMENSION OF TRADEMARKS}

Although marks are usually studied for their source- and quality-representing properties, they also serve an unheralded role as symbols of retail location. To see how the locationidentifying function works, we must return to the preindustrial world of Spark the Blacksmith. This will reveal the principles underlying the current role of marks in cyberspace.

356. See cases cited in supra notes $182-83$ and accompanying text.

357. For more on intellectual property and the Internet, see generally Dan L. Burk, Trademark Doctrines for Global Electronic Commerce, 49 S.C. L. REV. 695 (1998); Katherine E. Gasparek, Comment, Applying the Fair Use Defense in Traditional Trademark Infringement and Dilution Cases to Internet Meta Tagging or Linking Cases, 7 GEO. MASON L. REv. 787 (1999); Jeffrey R. Kuester \& Peter A. Nieves, Hyperlinks, Frames and Meta-Tags: An Intellectual Property Analysis, 38 IDEA 243 (1998); Maureen A. O'Rourke, Fencing Cyberspace: Drawing Borders in a Virtual World, 82 MINN. L. REv. 609 (1998). 


\section{The Storefront Sign}

As discussed earlier, a local manufacturer such as Spark might mark his goods to maintain their identity on the shelves of a local store. ${ }^{358}$ But suppose that Spark actually owned his own store and sold his products directly to consumers instead of relying on a merchant middleman. In that case, Spark would not really need to mark his goods, since they would not be comingled with competing products in his store.

Nevertheless, Spark would still need a mark to identify the location of his store. A storefront sign is the classic example of a mark acting as a location symbol. In the days before mass advertising and phone books, a sign was the best way to inform customers where they could find a particular retail outlet. Through a prominent horseshoe-shaped sign emblazoned with "Spark the Blacksmith," his mark told shoppers exactly where they could find genuine Spark products. Just as a mark's quality function makes it unnecessary for customers to scrutinize products before making a purchasing decision, the location function helps shoppers by eliminating the need for extensive window shopping to determine where a particular product is sold.

While the location function has always been an integral part of marks, it has not had much influence on the way lawyers look at trademark protection. To some extent, this is because the location function frequently overlaps with the source, product, and quality functions. For instance, in the case of a small manufacturer like Spark, the source and retail location of his goods would be essentially identical. Even if Spark's store was not literally at the same site as his forge, consumers came into contact with Spark products at only one place. As a result, the distinction between the source and retail location represented by a mark was insignificant. Location is also generally not a factor in how marks work in the modern age of mass retailers. 359 As long as people can find the location of the local omnibus department store, they can usually find any product they want. In other words, for many shoppers the "location" of a product is just a shelf in Wal-Mart. One could say that marks still identify the location of a product on that shelf. At that

358. See supra text accompanying notes 111-13.

359. E-commerce reverses this trend to some degree, since websites make it much easier for consumers to buy goods directly from manufacturers. 
point, however, there is little meaningful distinction between the mark's product and location-identifying features.

These two examples illustrate a more fundamental point, which is that modern consumers rarely rely on marks to figure out where particular stores and products are located. In its location-identifying role, marks convey information over a narrow area (i.e., the range of a sign), and hence their role in assisting consumers is quite limited. 360 Assume for a moment that you want to buy clothes from Banana Republic, but that you do not know where Banana Republic items are sold. The Banana Republic mark itself does not indicate where its store might be (unless you can see a Banana Republic sign from your house), but there are many ways to figure out where to go. You could ask friends for suggestions; look in the Yellow Pages; go through newspaper ads; or browse the Internet. But you are probably not going to hop in a car and drive around aimlessly until you stumble across a Banana Republic sign.

Stated more formally, the relative importance of a mark's location function will depend on three factors: (1) the range of the mark's location symbolism; (2) the availability and effectiveness of alternative search options; and (3) consumer expectations about the location a mark represents. As for the first factor, a bigger and more prominent storefront sign makes a mark a more powerful location beacon. With regard to the second factor, if people have many easy ways to find retail location information, as is true most of the time, then giving special attention to the location feature of marks will be unnecessary. Finally, people usually do not make assumptions about where a store is located based solely on that company's mark-unless they actually see some version of a storefront sign. Marks like McDonald's or Ben and Jerry's do not, in and of themselves, tell consumers much about where their retail outlets are located. ${ }^{361}$ In the ordinary case, therefore, the limited reach of the typical sign or billboard, the easy availability of location information, and the lack of consumer expectations about where particular

360. Of course, people using other means to find where a store is located (i.e., the Yellow Pages or ads) do rely on marks to match up the relevant information with a particular company. But marks in an ordinary advertisement are identifying a source or a product, not quality or location. The fact that quality or location information (or anything else) can be put into the ad does not mean that the marks themselves are conveying that information.

361. People might correctly assume that, for instance, a McDonald's will not be located next to the local landfill or chemical plant, but this does not help identify the specific location of a franchise. 
marks can be found render the mark's location function unimportant.

Other more exotic circumstances, however, point out the need to pay at least some attention to the relationship between marks and retail location. First, consider the example of restaurants at a highway rest stop. Customers who use these facilities are often far away from home and hence unfamiliar with the area they are passing through. If hungry drivers want to find a Wendy's, they have almost no choice except to drive around aimlessly until they see a Wendy's sign. Normal sources of location information will not be helpful. There are no friends around to give advice, and advertisements or directory listings describing a store's location are of limited value since the consumer will not know the local streets or addresses. Accordingly, when alternative sources of retail location information are inadequate, the mark's location function takes on greater importance and may warrant special protection. ${ }^{362}$

Next, think about the problems presented by a mark that does create expectations about retail location. If a local store is called "Joe's at 45 Main St.," it is only natural that people will think that Joe's is actually located at 45 Main Street. This expectation may well lead consumers to ignore other sources of information about the location of Joe's. After all, if there is a shortcut available from the information conveyed by the mark, then why should people take the time to look more carefully at where Joe's can be found? In that situation, the mark's location function again takes on greater importance, but this time due to consumer expectations (whether correct or not) about the information conveyed by the mark. ${ }^{363}$

As these examples demonstrate, uncovering the location function in action requires considerable effort. In real space, this effort is probably not worthwhile. In cyberspace, however, the location function becomes quite important.

362. In this scenario, doctrines designed to protect the source and quality functions may extend sufficient protection, but that presumption is problematic in the Internet context.

363. Just as in the prior example, trademark doctrine founded on protecting source and quality information might cover the problem. In addition, as a practical matter it is unlikely that anyone would include specific location information in their mark unless their store was already at that location. The possibility that someone else could profit by interfering with that mark's location function, therefore, is remote outside of cyberspace. See infra Part VI.B. 


\section{The Website}

Domain names (i.e., Internet addresses) are the storefront signs of the Internet, but the peculiar facts of life on line currently give the mark's location function heightened importance. ${ }^{364}$ Even though the Internet is still a recent development, consumers and businesses are rapidly turning to this new technology to buy goods, engage in financial transactions, and seek out commercial information. To take advantage of these exciting opportunities, people need to identify a company's retail location in cyberspace-its website. One of the consequences of the highly decentralized structure of the Web, however, is that there is still no effective directory or Yellow Pages of websites for the average user. ${ }^{365}$ As a result, finding information on particular products or companies can be a challenge.

A once-common Internet search technique is sometimes referred to as "trademark.com." Most company and brand web pages are located at a unique domain name comprised of the company or brand mark plus ".com." 366 Thus, if someone wanted to find Microsoft's website, an obvious first step would be to try "microsoft.com." This assumption made sense because ".com" is short for commercial, and companies customarily sought a ".com" designation for their domain name. Accordingly, courts adopted these Internet norms and repeatedly held that "trademark" and "trademark.com" were legally indistinguishable. ${ }^{367}$ Nevertheless, the assumption that company websites are located at "trademark.com" is often incorrect. There is nothing that prevents a firm from using some variant of its mark (e.g., msft instead of Microsoft) in its domain name, or other top-level domains (i.e., suffixes) like ".org," or ".net."

364. For a more technical explanation of how the Internet (or Web) works, see, e.g., Brookfield Communications, Inc. v. West Coast Entm't Corp., 174 F.3d 1036, 1044-45 (9th Cir. 1999).

365. Such a directory will probably be created someday. See infra Part VI.C. For now, the explosive growth of the Web seems to be outstripping the ability to catalogue websites.

366. The suffix ".com" is only one of many that can currently be used in a domain name. Others currently include ".edu" (educational), ".org" (organization), ".gov" (government), ".net" (network provider), and ".mil" (military). See Brookfield Communications, Inc., 174 F.3d at 1044.

367. E.g., Sporty's Farm L.L.C. v. Sportsman's Mkt. Inc., 202 F.3d 489, 497-98 (2d Cir. 2000), cert. denied, 120 S. Ct. 2719 (2000); Interstellar Starship Servs., Ltd. v. Epix Inc., 184 F.3d 1107, 1110 (9th Cir. 1999); Brookfield Communications, Inc., 174 F.3d at 1055 (collecting authorities). 
If "trademark.com" fails to locate the relevant information, then Internet users can turn to a search engine or a hierarchical index. A search engine is software that searches the Internet for particular websites based on the parameters of the search. 368 An intrepid consumer that puts Microsoft or some related term into the search engine, however, may well obtain a large list of websites that is "likely to deter web browsers from searching for [a] particular website." 369 This is because search engines work by looking for sites that frequently use key words in a particular search request. To find Microsoft, a search engine will retrieve a list of sites that repeatedly use words related to Microsoft in their text and in background code, also called metatags.

Metatags, which cannot be seen by web page users, are put into sites in order to make the site more accessible to search engines. 370 Due to the enormous number of Internet sites and the relatively crude (or unfamiliar) state of search technology, search engines are still a relatively blunt instrument. In some cases, it will be easy to determine which item on a search engine list is actually Microsoft's web page. But the search process often requires a user to wade through many different websites before the correct location becomes clear. ${ }^{371}$

Under these circumstances, the importance of the mark's location function in assisting consumers on the Internet is obvious. First, a domain name address identifies a company's retail location throughout all of cyberspace. Unlike an ordinary storefront sign, which is effective only within a limited line of sight, domain names have an unlimited reach within the realm of cyberspace. ${ }^{372}$ As a result, a mark's ability to convey location information on the Internet is much more potent than in "brick and mortar" space.373 Second, consumers currently expect that

368. For more on how search engines work, see Brookfield Communications, Inc., 174 F.3d at 1045; Nathenson, supra note 25, at 60-65.

369. Teletech Customer Care Mgmt., Inc. v. Tele-Tech Co., 977 F. Supp. 1407, 1410 (C.D. Cal. 1997).

370. See Brookfield Communications, Inc., 174 F.3d at 1045; Nathenson, supra note 25 , at $62-65$.

371. Panavision Int'l, L.P. v. Toeppen, 141 F.3d 1316, 1327 (9th Cir. 1998).

372. This is an illustration of the importance of "architecture" in shaping the regulation of cyberspace. See LAWRENCE LESSIG, CODE AND OTHER LAWS OF CYBERSPACE 30-42 (1999).

373. "Brick and mortar" refers to traditional stores that occupy physical space. In a certain sense, there is analogy between the greater scope the Internet has given to the mark's location role and the wider range mass mar- 
a particular company's website will be at "trademark.com." 374 In line with the earlier analysis, this strong consumer presumption that the mark actually identifies retail location makes that function more important. ${ }^{375}$ Third, alternative Internet search options are still somewhat limited, a factor that is inversely related to the strength of the location function. As mentioned earlier, there is still no directory of web pages akin to the Yellow Pages, and search engine technology still cannot effectively isolate specific websites for the average user.

Search engines as currently constituted also depend on marks as keywords to help locate websites. ${ }^{376}$ Thus, the effectiveness of Internet search technology itself can be influenced by actions that substantially impair the mark's location function. This adds a new wrinkle to the simple model presented earlier. The prior discussion assumed that the effectiveness of alternative search options and the strength of consumer expectations were independent factors in determining the importance of the location-identifying function of the mark. On the Internet, however, consumers frequently use marks when using search engines precisely because of their expectation that the mark has some relationship to a domain name address. Put another way, location-function clarity is itself critical for the primary search option-search engines-to function well.377

keting gave to the mark's quality function during the early part of this century. See supra text accompanying note 127.

374. See, e.g., Panavision Int'l, 141 F.3d at 1325. Some have argued that this expectation is misguided and should hence be treated as "user carelessness." Jon H. Oram, Note, The Costs of Confusion in Cyberspace, 107 YALE L.J. 869, 873 (1997).

375. This would not change much if people understood that company domain names might well show up at "trademark.org" or "trademark.net" instead of "trademark.com." Naturally, this would weaken consumers' assumptions about finding things at "trademark.com," but people would still be inclined to think that a company's mark was an integral part of its domain name.

376. This is different from the situation with phone numbers. A phone directory does rely on marks to match up the relevant number with a particular company. Phone directories or operators, however, are quite precise and can almost always match a search to a specific number. Search engines are not yet this accurate. In response to a search request, the best they can do is generate a large list of probable websites, which leaves the consumer in the position of figuring out which one is the page he or she needs. For more on the relationship between phone numbers and domain names, see infra Part VI.C.

377. One objection is that marks cannot be important both for search engines and for a "trademark.com" search. According to this view, users who fail to find the website they are looking for at "trademark.com" will not use the mark as a term in a search engine inquiry. Thus, at least for those Internet 
Accordingly, the factors that bear on the relative importance of the location function and the need to provide extra protection to marks acting in a location capacity blend with each other in an Internet context. ${ }^{378}$

These contextual elements, combined with the Internet's explosive growth, have transformed the trademark within cyberspace. Indeed, it would not be much of an exaggeration to say that the location function is currently the most important aspect of marks on the Web. This is, of course, a complete reversal of the role marks play in brick-and-mortar commerce. The next section examines the implications of this paradigm shift for trademark law and shows how dilution and infringement have responded in their familiar fashion.

\section{B. APPLYING LOCATION: CYBERSQUATTING AND METATAGS}

Cybersquatting and metatag abuse are two impairments of the mark's location symbolism that have drawn considerable attention. Obsolete consumer confusion law initially led courts and commentators to use dilution as a way of protecting the mark's newly enhanced location function. Within just a few years, however, the scope of consumer confusion has expanded to such an extent that dilution may no longer be needed to safeguard the special role of marks on the Web.

users who conduct "trademark.com" searches before turning to search engines, the location function is of limited importance for effective search engines.

There is some truth to this observation, but as more domain name suffixes are developed for commercial use (e.g., ".aero," ".biz," ".coop," ".info," ".museum," ".name," and ".pro") over the next few years, the "trademark.com" method of searching will become very unreliable. See Ariana Eunjung Cha, New Web Domains Provoke .deja vu: Suffix Expansion Starts Address Grab, WASH. POST, Nov. 18, 2000, at E1. Under those circumstances, search engine inquiries will become even more important because there will be no other effective method for finding websites except by plugging in some variant of the company's mark into a search engine.

378. The most critical variable is almost certainly consumer expectations. If people did not instinctively link marks and domain names, then the importance of the mark's location function would shrink considerably. After all, in brick-and-mortar space people do not normally make that association. On the other hand, expectations do not develop out of thin air. People commonly refer to the new Internet economy as the "dot.coms" because most companies are, in fact, located at a "trademark.com" address. Figuring out which came firstthe consumer expectation or the facts upon which the expectation is based-is a headache best left to someone else. 


\section{Cybersquatting}

Cybersquatting is the clearest example of a substantial impairment of the location function. This involves the registration of another's mark as a domain name by third-parties who then seek to sell the name back to the senior user. Until recently, domain names could be obtained only from Network Solutions, Inc. (NSI), a private company that dispensed names under an exclusive contract with the federal government. ${ }^{379}$ NSI granted domain names for a nominal fee on a first-come, first-serve basis, and generally did not inquire into whether a given request would conflict with existing marks. ${ }^{380}$ As a result of this regulatory failure, so-called "cybersquatters" acquired valuable trademark rights at the expense of the mark owner.

More important, by taking the location that consumers think the senior user should occupy, cybersquatters obviously make it difficult for consumers and search engines to use marks as a reliable symbol of retail location. First, cybersquatters render the "trademark.com" approach to searching the Web unworkable by undermining consumer expectations about the location information conveyed by marks. When those same consumers turn to a search engine for help, cybersquatting creates mischief by making it more difficult to distinguish the real "trademark.com" from the cybersquatter. To the extent that a search engine looks for pages identified by a particular mark, web pages with similar domain names just crowd the field and cause additional delays in finding the correct web page. ${ }^{381}$

Notwithstanding the problems created by cybersquatting, infringement did not initially offer mark owners a remedy. ${ }^{382}$

379. See Avery Dennison Corp. v. Sumpton, 189 F.3d 868, 872 (9th Cir. 1999). In 1999, a new competitive scheme of domain name allocation was implemented. Id. at 872 n.1.

380. See Brookfield Communications, Inc. v. West Coast Entm't Corp., 174 F.3d 1036, 1044 (9th Cir. 1999) (stating that NSI did not check whether its registrants have any right to use a particular domain name).

381. One could say that the resulting delays in finding the correct web page are not significant enough to warrant special protection. In this early stage of the Internet's development, however, the costs of such delays may be high.

382. Many have argued that cybersquatting is not a problem at all. If a junior user registers a "trademark.com" before the mark owner does, then perhaps that junior user should reap the rewards. A mark owner could, as many have, just buy the domain name from the cybersquatter and make everyone better off. Establishing a first-in-time rule for domain names could encourage the development of cyberspace by minimizing litigation and forcing mark owners to claim their space on the Internet sooner rather than later.

While this argument is intriguing, there are two obstacles. First, the law 
The problem was that infringement doctrine assumed that there could be no potential consumer confusion unless the junior user actually sold something. ${ }^{383}$ Such a requirement made sense because, before the Internet, there was no reason to believe that a junior user would take another company's mark unless it sold something and could therefore profit from using the mark. Limiting infringement protection to cases where the junior user sells goods, however, is now just as obsolete as the common-law rule that once restricted infringement relief to situations where a junior user directly competed with a mark owner. Once the primary value of the mark inheres to its location function, however, someone does not need to sell things to profit from another's mark. A cybersquatter can ransom a domain name since consumers expect a particular company's to be at that address and cannot easily find the web page by other means.

In the face of infringement's obsolescence on this question, courts once again turned to dilution as a way of protecting marks during their transformative phase. ${ }^{384}$ The passage of the FTDA in 1995, just as e-commerce was getting off the ground, may have been more than a coincidence. In a statement that many courts have cited, Senator Leahy commented during the FTDA debate that "[i]t is my hope that this antidilution statute can help stem the use of deceptive Internet addresses taken by those who are choosing marks that are associated with the products and reputations of others." 385 Because of dilution's breadth, courts have found it pretty easy to con-

has unequivocally rejected this view, as this Part explains, second, when the bargaining for a domain name involves only two parties-the senior user and the cybersquatter-the resulting "bilateral monopoly" generates high transaction costs. See RICHARD A. POSNER, ECONOMIC ANALYSIS OF LAW 61-62 (4th ed. 1992). This may make it difficult for effective contractual solutions to develop.

383. See 15 U.S.C. $\S \S 1114(1)(a), 1125(a)(1)$ (1994); Duffey, supra note 15, at 147. Of course, if a junior user acquired a senior user's "trademark.com" and started selling goods there, courts could easily use traditional source and quality confusion to enjoin the junior use. See Brookfield Communications, Inc., 174 F.3d at 1054-61.

384. See, e.g., Panavision Int'l L.P. v. Toeppen, 141 F.3d 1316 (9th Cir. 1998); Jews for Jesus v. Brodsky, 993 F. Supp. 282 (D.N.J. 1998); Teletech Customer Care Management, Inc. v. Tele-Tech Co., 977 F. Supp. 1407 (C.D. Cal. 1997); Intermatic, Inc. v. Toeppen, 947 F. Supp. 1227 (N.D. Ill. 1996); Duffey, supra note 15, at 148-49.

385. 141 CONG. REC. S19312-01, S19312 (daily ed. Dec. 29, 1995) (statement of Sen. Leahy). Admittedly, Leahy was the only Senator who expressed any interest in how dilution would regulate cyberspace. 
struct a theory of how cybersquatting dilutes a mark's selling power. ${ }^{386}$ As the Ninth Circuit has said, "[P]otential customers ... will be discouraged if they cannot find [a] web page by typing in [trademark.com], but are instead forced to wade though hundreds of websites. This dilutes the value of [a] trademark." 387 Nevertheless, we should not be misled as to what was going on. Courts were using dilution to protect the mark's location function because infringement was obsolete. Moreover, it should be noted that this development would have been impossible had the FTDA been read to incorporate an "actual dilution" standard of proof.

Although there are indications that the common law was moving to expand infringement to cover cybersquatting, the passage of the Anti-cybersquatting Consumer Protection Act (ACPA) in 1999 resolved infringement's temporary obsolescence and effectively eliminated dilution's role in this context. 388 The statute was designed to remedy a specific problem, but it also works a significant change in confusion doctrine by eliminating the requirement that a junior user actually sell products before being held liable for trademark infringement. The ACPA provides, in pertinent part,

A person shall be liable in a civil action by the owner of a mark,... if, without regard to the goods or services of the parties, that person-

(i) has a bad faith intent to profit from that mark, ...; and

(ii) registers, traffics in, or uses a domain name that-in the case of a mark that is distinctive at the time of registration of the domain name, is identical or confusingly similar to that mark; in the case of a

386. There are some difficulties in using dilution for cybersquatting. First, the FTDA requires that the junior use be "commercial" to receive protection. If cybersquatters did not sell any goods, then how could their actions be commercial? Courts answered this question by ruling that cybersquatters were engaged in commercial activity by seeking to sell the name itself back to the senior user. See, e.g., Panavision, 141 F.3d at 1325. But see Golinveaux, supra note 26, at 641 (stating that courts have misapplied the "commercial use" requirement to get at cybersquatters). Second, the FTDA only protects famous marks. What if someone cybersquatted on a non-famous mark? In practice, the answer is that all marks attacked by cybersquatters were found to be "famous," whether they were really famous or not. See supra note 97.

387. Panavision, 141 F.3d at 1327 . Courts have generally treated cybersquatting as a separate category of dilution distinct from blurring and tarnishment. See id. at 1326.

388. See Anticybersquatting Consumer Protection Act of 1999, Pub L. No. 106-113, 113 Stat. 1501; Sporty's Farm L.L.C. v. Sportsman's Market, Inc., 202 F.3d 489 (2d Cir. 2000). Some British courts have extended infringement protection in cybersquatting cases. See British Telecomms. P.L.C. v. One in a Million, Ltd. (Ch. 1997); Golinveaux, supra note 26, at 670. 
famous mark that is famous at the time of registration of the domain name is identical or confusingly similar to or dilutive of that mark . . . . 389

All valid marks will now receive protection from cybersquatters through a broadened confusion test. Although the new statute retains some dilution language, it is hard to see how dilution will add much to the protection given by the ACPA's confusion section. ${ }^{390}$ In just a few years, mainstream trademark law has adapted to this part of the Internet's challenge.

\section{Metatags}

A second aspect of the new mark's location function involves the abuse of metatags. Recall that metatags are invisible codes that are put into web pages to attract search engines. Given the reliance of Internet users on search engines, unscrupulous web site managers have an opportunity. By putting numerous references in their metatags to common search terms, even if the words have nothing to do with the substance of the web site, designers increase the odds that their page will be picked up by search engines. ${ }^{391}$ One example would be to put words such as sex or pornography into metatags. While an Internet user is looking over the list of pornography pages pulled up by the search, he or she will also see the pages of unrelated companies with the misleading metatags. Along the way, the user may decide to pause and buy something from them.

Trademark law becomes involved when someone tries to use another's marks to "stuff" their metatags. To return to our

389. Pub L. No. 106-113, § 3002(d)(1)(A)(i)-(ii), 113 Stat. 1501, 1501A.54546 (1999) (emphasis added). In addition to the ACPA, an elaborate international arbitration system has now been set up to resolve domain name disputes using similar principles.

390. See supra text accompanying notes 168-70 (noting the claim by critics that dilution is superfluous). Of course, the ACPA uses a "confusingly similar" standard rather than "likelihood of confusion." See Sporty's Farm, 202 F.3d at 497 n.11. Under a "confusingly similar" test, courts usually compare only the marks themselves and ignore the contextual Polaroid factors. See Wella Corp. v. Wella Graphics, Inc., 37 F.3d 46, 48 (2d Cir. 1994). This does not mean, however, that contextual factors are irrelevant under the ACPA. See Sporty's Farm, 202 F.3d at 498 n.12, 499 (setting forth some contextual elements that are useful in evaluating the bad faith element in the statute). Instead, the ACPA simply recognizes that the Polaroid framework may not work well against the threat posed to the location-function by cybersquatting.

391. See Nathenson, supra note 25, at 60-65. 
Microsoft example, any web site manager can take advantage of Microsoft's strength by putting hundreds of references to Microsoft in the page's metatags. This substantially impairs Microsoft's ability to function as a location identifier. People who enter Microsoft in their search engine under this scenario might receive thousands of different kinds of web pages, and the false web pages will probably contain more references to Microsoft than the Microsoft web page itself. At that point, the Microsoft mark would have virtually no value as a locationidentifier. Accordingly, unless something is done to protect senior users from metatag abuse, their marks will be unable to discharge their location function on the Internet and consumers will suffer. This problem explains why companies are currently so eager to have "trademark.com" as their domain name.

In the metatag context, the once-controversial doctrine of "initial interest confusion" comes to the rescue. Initial interest confusion holds that the use of a mark "to capture initial consumer attention, even though no actual sale is finally completed as a result of the confusion, may still be an infringement."392 This would seem to address the circumstances of metatag abuse quite well. All the metatag fiend wants to do is draw attention to his web site just long enough to get someone interested in buying something. Clearly, if someone enters a search for Microsoft and instead gets a website for comic books, he or she will not think that the comic book web page is related to Microsoft. Nevertheless, the momentary confusion generated before the user realizes that a comic book site has popped up could be actionable under infringement.

Critics of initial interest confusion have generally assailed the concept as too broad. ${ }^{393}$ But several commentators have

392. Dr. Seuss Enters. v. Penguin Books, USA, Inc., 109 F.3d 1394, 1405 (2d Cir. 1997); see Grotrian, Helffrich, Schulz, Th. Steinweg Nachf. v. Steinway \& Sons, 523 F.2d 1331 (2d Cir. 1975). Initial interest confusion has been described as "a brand of confusion particularly applicable to the Internet." Playboy Enters., Inc. v. Netscape Communications Corp., 55 F. Supp.2d 1070, 1074 (C.D. Cal 1999).

393. See, e.g., Astra Pharm. Prods., Inc. v. Beckman Instruments, Inc., 718 F.2d 1201, 1206-08 (1st Cir. 1983) (arguing that only confusion that influences "the ultimate decision of a purchaser whether to buy a particular product" can support infringement actions); Teletech Customer Care Mgmt., Inc. v. TeleTech Co., 977 F. Supp. 1407, 1414 (C.D. Cal. 1997) (concluding that initial interest confusion is not cognizable under the Lanham Act); see also Munsingswear Inc. v. Jockey Int'l Inc., 31 U.S.P.Q.2d (BNA) 1146, 1149 \& n.6 (D. Minn.), affd, 39 F.3d 1184 (8th Cir. 1994) (noting the split in authority on initial interest confusion). This Article takes no position on the validity of ini- 
concluded that dilution is the best answer to metatag abuse. ${ }^{394}$ Ira S. Nathenson states the case against using initial interest confusion for metatags:

Initial interest confusion... is a weak hook on which to sustain trademark infringement. First, if this confusion ever truly exists, it is fleeting. Second, by allowing liability to attach even if confusion as to the source of the goods is dispelled by the time any sales are consummated, it cannot be said that reasonable consumer expectations are being protected. If consumer confusion is the loadstone for trademark infringement, then why impose liability when no realistic possibility of confusion exists? ${ }^{395}$

This sounds just like the language of the conservatives in the Second Circuit who once argued that expanding the confusion test to non-compete cases would give mark owners an undesirable monopoly. ${ }^{396}$ Attacks on initial interest confusion are based on the fallacy that preventing consumer confusion is an end in itself rather than a means of protecting vital trademark functions. Nevertheless, it is interesting that Nathenson, like Schechter before him, considered dilution an acceptable source of protection for the transformed trademark while being unable to extend the same bouquet to an expansion of the confusion test.

The only significant case to address metatag abuse gave a strong endorsement of initial interest confusion. ${ }^{397}$ In Brookfield Communications, Inc. $v$. West Coast Entertainment Corp., the plaintiff, a marketer of entertainment information, brought an infringement action against defendant, a video rental outfit, that used plaintiff's mark in its metatags. ${ }^{398}$ Applying initial

tial interest confusion in brick-and-mortar commerce.

394. See Nathenson, supra note 25, at 114-16; Maureen O'Rourke, Defining the Limits of Free-Riding in Cyberspace: Trademark Liability for MetaTagging, 33 GoNZ. L. REV. 277, 298-300 (1997-1998).

395. Nathenson, supra note 25 , at 115 (internal quotation marks and footnote omitted). He goes on to say that dilution provides the best framework for evaluating metatag claims. See id. at 118-24.

396. See supra Part IV.C.

397. See Brookfield Communications, Inc. v. West Coast Entm't Corp., 174 F.3d 1036, 1062-65 (9th Cir. 1999). One might wonder why this court was able to move directly to adapt the confusion test rather than relying on dilution to manage the transition. The answer lies in the fact that the parties in Brookfield were virtually direct competitors. See $i d$. at 1056 ("Not only are they not non-competitors, the competitive proximity of their products is actually quite high."). This made it easier for the court to view the case in traditional "confusion" terms. Metatag cases involving non-competitors may, however, still need dilution to support an extension of protection.

398. See id. at 1041-43. 
interest confusion, the court found for the plaintiff. ${ }^{399}$ In the course of its analysis, the court used an analogy that confirmed the critical role of the mark's location function in cyberspace:

Using another's trademark in one's metatags is much like posting a sign with another's trademark in front of one's store. Suppose West Coast's competitor (let's call it "Blockbuster") puts up a billboard on a highway reading "West Coast Video: 2 miles ahead at Exit 7" - where West Coast is really located at Exit 8 but Blockbuster is located at Exit 7. Customers looking for West Coast's store will pull off at Exit 7 and drive around looking for it. Unable to locate West Coast, but seeing the Blockbuster store right by the highway entrance, they may simply rent there. Even consumers who prefer West Coast may find it not worth the trouble to continue searching for West Coast since there is a Blockbuster right there. ${ }^{400}$

To confirm its finding of initial interest confusion and extend trademark protection, the court employed the logic of location. This is a good start for the adaptation of infringement doctrine, but what is the future of the location function on the Web?

\section{BACK INTO THE FOLD}

Even though the Internet has witnessed the familiar ebb and flow of dilution and infringement, there is one critical difference that bears on the continuing vitality of the mark's location function in cyberspace. Unlike the transformation of marks into quality symbols by the Industrial Revolution, the shift in marks brought on by the Internet may be only temporary. The main reason that people rely on marks to find web sites is that alternative search options are inadequate. As ecommerce becomes more common and the architecture of the Internet becomes more user-friendly, however, finding a web site could eventually become as easy as finding a brick-andmortar store. At that point, the mark's role as a location identifier would diminish considerably.

Domain names may end up looking like phone numbers. Phone numbers usually do not convey location information, nor do people expect them to. Any company's phone number can be easily accessed through the Yellow Pages or operator assistance. But this was not the only way phone numbers could have developed. If directory assistance did not exist, companies that conducted a lot of business over the phone would probably have been forced to use numbers composed of their mark to

399. See id. at 1066.

400. Brookfield Communications, Inc., 174 F.3d at 1064 (emphasis added). 
convey location information. This in turn would have led consumers to rely on phone numbers for that information. And in some situations involving novelty numbers, courts have extended trademark protection. ${ }^{401}$ Nevertheless, this constitutes the exception rather than the rule.

While there may be other location function problems in the years to come, the story of marks on the Internet fits the pattern established by decades of trademark cases. As marks undergo a radical shift in purpose brought on by new technology, dilution takes the lead in trademark protection due to its greater flexibility. Eventually, infringement catches up by broadening the definition of consumer confusion. Both doctrines are now awaiting further developments.

\section{CONCLUSION}

Dilution and infringement are one and inseparable. Born out of frustration with the slow evolution of the common law, dilution spurred the growth of trademark protection during an era of economic transition. As infringement gradually emerged from the shadow of obsolescence, dilution went into a corresponding decline, with only tarnishment surviving as an echo of the past. With the rebirth of the trademark in recent years as an important symbol of retail location, dilution reemerged to prevent the substantial impairment of this particular trademark function while the likelihood of confusion test once again adapted.

This analysis of dilution's role within trademark law, however, cannot answer the ultimate question of whether dilution statutes are a good idea. After all, given enough time, infringement has proved capable of meeting the challenges created by trademark change. Indeed, the legal system as a whole has been remarkably nimble in the face of the most recent shock to trademark protection created by the Internet. Dilution, on the other hand, can be easily misused by courts eager to give mark owners the benefit of the doubt. Moreover, as the case law demonstrates, even after seventy years dilution remains a tricky concept to apply.

In the end, the desirability of dilution depends on our patience with the common law process. A world without dilution would still be a happy one, but the felt necessities of trademark

401. See, e.g., Dial-A-Mattress Franchise Corp. v. Page, 880 F.2d 675 (2d Cir. 1989) (granting protection to 1-800-MATRESS). 
protection will sometimes go unmet. For those who just cannot endure these brief periods of uncertainty, dilution offers a potential solution. Understanding the limits of that solution, however, is the only rational basis for dilution interpretation. 